THIERRE ZULZKE PENTEADO

ESTUDO DE ESCOAMENTO DE AR EM DUTOS COM MÚLTIPLAS SAÍDAS 
THIERRE ZULZKE PENTEADO

\section{ESTUDO DE ESCOAMENTO DE AR EM DUTOS COM MÚLTIPLAS SAÍDAS}

Dissertação apresentada à Escola Politécnica da Universidade de São Paulo para obtenção do título de Mestre em engenharia

Área de concentração: Engenharia Mecânica de Energia de Fluidos

Orientador: Prof. Dr. Otávio de Mattos Silvares 
Catalogação-na-publicação

Penteado, Thierre Zulzke

Estudo do escoamento de ar em dutos com múltiplas saídas / T.Z. Penteado. -- versão corr -- São Paulo, 2014.

$117 \mathrm{p}$.

Dissertação (Mestrado) - Escola Politécnica da Universidade de São Paulo. Departamento de Engenharia Mecânica.

1.Escoamento 2.Mecânica dos fluídos computacional 3.Método dos volumes finitos I.Universidade de São Paulo. Escola Politécnica. Departamento de Engenharia Mecânica Il.t. 
Dedico este trabalho aos meus amigos, familiares e a você, leitor. 


\section{AGRADECIMENTOS}

Ao meu amigo e orientador, Prof. Dr. Otávio de Mattos Silvares, por aceitar me acompanhar nessa jornada, suas palavras dentro e fora das salas de aula foram inspiradoras e necessárias, agradeço pelas necessárias broncas e pelo sorriso sincero de sempre.

Ao amigo e praticamente orientador, Prof. Dr. Antônio Luís de Campos Mariani, pela paciência em ouvir, ler e reler esse texto. Sei que dei mais trabalho do que deveria, mas quero dizer que jamais saberei expressar o quão importante 0 senhor tem-me sido nesses anos.

À amada Natalia, que com sua presença luminosa tem sido a luz, a energia e a guia de minha vida, obrigado pela sabedoria compartilhada, e saiba que sua visão romântica da ciência serviu-me diversas vezes de inspiração.

Aos meus pais Carlos e Fátima por acreditarem que o ensino é capaz de mudar a vida das pessoas. Seus esforços incansáveis tornaram possível não só que eu estivesse aqui, mas também que eu fosse o homem que sou hoje.

À minha pequena irmã Thaís, que mesmo estando longe me traz alegria apenas com um sorriso.

Aos amigos da Voith Paper, em especial ao amigo Elivaldo por propor e viabilizar esse desafio e aos amigos do PEC-A Rodrigo, Mauro, Henrique e Luccas, pelo companheirismo de sempre, pelas risadas e pelas ajudas.

Ao amigo Alexandre D’Agostini Neto, cuja obstinação pela perfeição e pela ciência bem feita é só menor do que sua disposição em ajudar, obrigado camarada! 
Aos meus amigos voluntários, alunos e ex-alunos do projeto Formare, que em sua sede por conhecimento me motivaram nos momentos difíceis, e que com seu acolhimento me mostraram como ser um educador melhor.

A todos os funcionários do Departamento de Engenharia Mecânica, que fazem o possível para deixar nossa vida de acadêmica, menos complicada.

Aos que acreditam no ensino e na ciência, que vocês se mantenham firmes e persistentes, pois os desafios serão grandes, mas jamais intransponíveis! 
"Diante da vastidão do tempo e da imensidão do universo, para mim é um imenso prazer, dividir um planeta e uma época com você."

Carl Sagan 


\section{RESUMO}

Este trabalho apresenta um estudo sobre o escoamento de ar em dutos com múltiplas saídas que são identificados como caixas sopradoras, quando instalados em máquinas desaguadoras de celulose. Estas caixas auxiliam o processo de secagem conduzindo ar aquecido até um conjunto de orifícios que produzem jatos que são impingidos sobre as folhas de celulose fabricadas. É realizada revisão bibliográfica abordando processos e equipamentos de secagem, com foco no escoamento de ar, métodos para solução numérica de escoamentos, seus modelos e parâmetros, e abordagem semi-empírica para fluxos de ar na saída de dutos. O escoamento do ar no interior da caixa sopradora e nos jatos de saída são estudados através de simulação numérica, e de modelo semi-empírico. São propostas duas alternativas de geometria para estes dutos de modo que se garanta a maior uniformidade possível na vazão e na velocidade média do ar que saí através dos orifícios Na primeira alternativa considera-se que a seção transversal da caixa sopradora se mantém constante. $\mathrm{Na}$ segunda se considera que a seção transversal seja reduzida de modo uniforme ao longo da caixa sopradora. Um estudo experimental sobre o comportamento do escoamento de ar para caixas sopradoras em escala reduzida apresenta resultados que possibilitam validar um conjunto de valores numéricos obtidos na simulação e também estabelecer características para o escoamento de modo a atender o processo de secagem. Para cada alternativa são adotadas duas condições de vazão de ar. Os resultados obtidos pela da simulação numérica e modelagem semi-empírica validam um perfil geométrico adequado para que a caixa sopradora produza um conjunto de jatos nas suas saídas com valores de velocidade média. Um dos principais resultados foi obtido para a caixa com 275 orificios, na qual as velocidades médias estiveram dentro do intervalo de $32,5 \mathrm{~m} / \mathrm{s}$ e $33,1 \mathrm{~m} / \mathrm{s}$, que representou um ótimo resultado em termos de balanceamento e uniformidade das vazões de ar

Palavras-chave: Escoamento de ar. Dutos com múltiplas saídas. Secagem. Mecânica dos fluidos computacional. 


\begin{abstract}
This study presents an analysis about airflow in ducts with multiple outlets that are identified as blow boxes, when installed in pulp dewatering machines. These boxes work in the drying process leading heated air to a set of nozzles that produce air jets that are impinged against the pulp sheet. It is performed literature review about drying processes and equipment, with a focus on air flow, methods for numerical solution of airflows, their models and parameters, and semi-empirical approach about airflow at the outlets of the duct. The airflow inside the blow box and the output jets are studied by numerical simulation, and semi-empirical model. It is proposed two alternative geometries for these ducts in order to guarantee the greatest possible uniformity in flow rate, and in the average velocity of air jets. In the first alternative is considered that the cross section of the blow box remains constant. In the second one it is considered that the cross section is reduced uniformly along the blow box. An experimental study about the behavior of the airflow in blow boxes, using scaled models, presents results that can validate a set of numerical values obtained in the simulation and also establish characteristics for the drying process. For each alternative two conditions of airflow are adopted. The results obtained through numerical simulation and semi-empirical modeling validates an appropriate geometrical profile for the blow box in order to set the values of average speed within the range required by the drying process. One of the principal results, obtained for the case of boxes with 275 holes, was the average speed within the range of $32,5 \mathrm{~m} / \mathrm{s}$ and $33,1 \mathrm{~m} / \mathrm{s}$, this range represents a great result in tterms of balance and uniformity of air flow.
\end{abstract}

Keywords:.Airflow. Ducts with multiple outlets. Drying. Computational fluid mechanics 


\section{LISTA DE FIGURAS}

Figura 1 - Exemplo seção de secagem de uma máquina de papel (Voith Paper, 2011). 10

Figura 2 - Exemplo de seção de secagem de uma máquina de papel tissue (Voith Paper 2011). 11

Figura 3 - Leiaute básico de um flakt dryer (Andritz 2010). 12

Figura 4 - Posicionamento das caixas sopradoras durante a passagem da folha de celulose (Andritz 2010) 13 Figura 5 - Exemplo de seção de secagem de máquina desaguadora de celulose (Andritz, 2010) 13

Figura 6 - Exemplo de arranjo vertical de uma seção de secagem de uma máquina desaguadora de celulose.

Figura 7 - Leiaute típico de uma máquina de fabricação de papel (Voith Paper, 2011). 15

Figura 8 - Seção de prensas (Voith Paper, 2011). 16

Figura 9 - Seção de formação (Voith Paper, 2011). 17

Figura 10 - Seção de secagem para uma planta de fabricação de filmes revestidos (Aust et al. 1997) 19

Figura 11 - Esquema simplificado de uma seção de secagem com cilindros secadores. 21

Figura 12 - Caixa sopradora com orifícios oblíquos (vermelho) e perpendiculares (preto).

Figura 13 - Vista frontal de um secador horizontal (Bates 2010, editado)....... 25

Figura 14 - Esquema experimental adotado (Milosavljevic; Heikkilä, 2004, editado).

Figura 15 - Variação de $\alpha$ em função da distância radial e da temperatura do ar (Milosavljevic; Heikkilä, 2004)

Figura 16 - Representação esquemática das direções referentes ao fluxo de ar e à folha 29

Figura 17 - Comportamento da vibração da folha em função da alteração da velocidade de escoamento (Chang e Moretti 2002, editado). 30 
Figura 18 - Dutos de seção transversal variável com múltiplos canais (Idelchik, 2008).

Figura 19 - Vista superior de um leiaute de uma câmara de secagem (Penteado, 2012) 44

Figura 20 - Direção do fluxo de ar e geometria câmara de secagem para 16 colunas de caixas sopradoras, faces em vermelho são as regiões dos orifícios. (Penteado, 2012)

Figura 21 - Modelo numérico com malha para a da câmara de secagem (Penteado, 2012) .................................................................... 46

Figura 22 - Vazão Mássica de ar por caixa sopradora (Penteado, 2012)....... 47

Figura 23 - Exemplo da numeração utilizada para as caixas sopradoras ....... 48

Figura 24 - Exemplo de modelos ensaiados (Voith Paper, 2011). .................. 50

Figura 25 - Vista da face perfurada de uma caixa sopradora...................... 53

Figura 26 - Geometria do modelo considerado. .................................. 53

Figura 27 - Modelo numérico utilizado para caixa sopradora seção variável. . 55

Figura 28 - Vista da face perfurada para caixa sopradora de teste. ...............56

Figura 29 - Malha numérica da caixa sopradora. .................................... 57

Figura 30 - Detalhe das malhas utilizadas na simulação numérica. Vista de

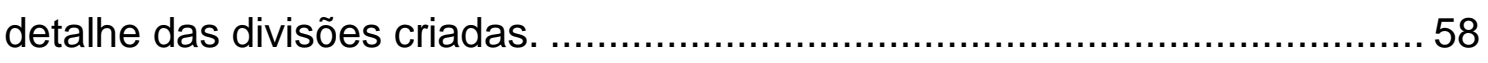

Figura 31 - Principais condições de contorno para a vista da caixa sopradora pela face de entrada do ar......................................................... 59

Figura 32 - Principais condições de contorno da caixa sopradora, vista

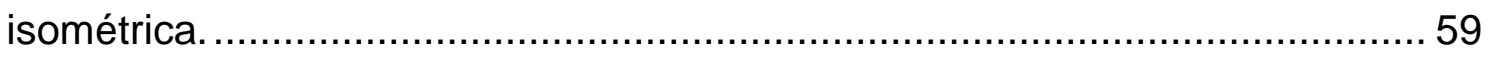

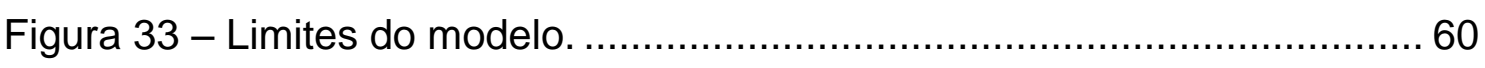

Figura 34 - Valores de velocidade da saída do ar para a caixa sopradora de

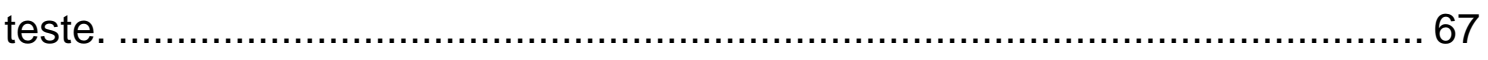

Figura 35 - Detalhe da contração jato para a caixa sopradora de teste. .........6 67

Figura 36 - Valores de pressões para a caixa sopradora de teste. .................68

Figura 37 - Velocidade Jato x Orifício - Caixa sopradora seção uniforme e

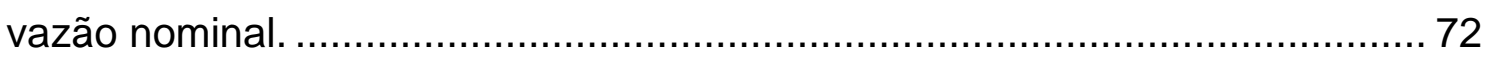

Figura 38 - Velocidade Jato x Orifício - Caixa sopradora seção uniforme e vazão $30 \%$ maior que a nominal 73 
Figura 39 - Variação de pressão no interior da caixa sopradora - Modelo com vazão nominal.

Figura 40 - Variação de pressão no interior da caixa sopradora - Modelo com

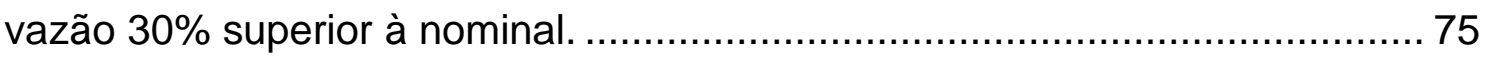

Figura 41 - Vetores de velocidade na região dos orifícios............................. 76 Figura 42 - Velocidade Jato x Orifício - Caixa sopradora de seção transversal variável e vazão nominal. .......................................................................... 78

Figura 43 - Velocidade Jato x Orifício - Caixa sopradora seção transversal variável e vazão 30\% superior que a nominal. .............................................. 79

Figura 44 - Variação de pressão no interior da caixa sopradora - Modelo com

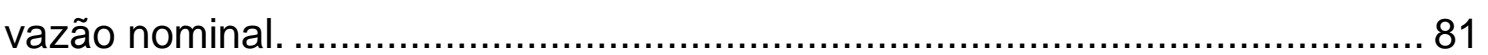

Figura 45 - Variação de pressão no interior da caixa sopradora - Modelo com

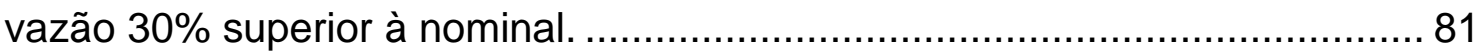

Figura 46 - Vetores de velocidade na região dos orifícios............................... 82 Figura 47 - Variação da largura da caixa sopradora em função das colunas de orifícios. 83

Figura 48 - Variação da largura da caixa sopradora em função das colunas de orifícios. 84

Figura 49 - Variação da pressão na caixa sopradora em função das colunas de orifícios. 


\section{LISTA DE TABELAS}

Tabela 1 - Número de Reynolds para os modelos de caixa sopradora com

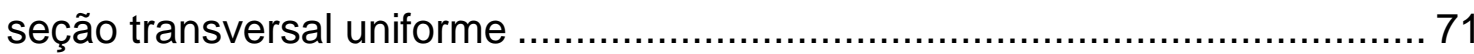

Tabela 2 - Número de Reynolds para os modelos de caixa sopradora de seção transversal variável

Tabela A1 - Velocidades médias nas linhas de orifícios para a caixas sopradora de seção uniforme e vazão nominal. 92

Tabela A2 - Velocidades médias nas linhas de orifícios para a caixas sopradora de seção transversal uniforme e vazão $30 \%$ superior a nominal. ... 93 Tabela A3 - Velocidades médias nas linhas de orifícios para a caixas sopradora de seção transversal variável e vazão nominal.

Tabela A4 - Velocidades médias nas linhas de orifícios para a caixas sopradora de seção transversal variável e vazão $30 \%$ superior a nominal...... 95 Tabela B1 - Parâmetros de entrada para o modelo semi-empírico sem perdas de energia. 96

Tabela B2 - Resultados de pressão interna, velocidade interna e perfil para a caixa sopradora para o modelo semi-empírico sem perdas de energia

Tabela B3 - Parâmetros de entrada para o modelo semi-empírico com perdas de energia.

Tabela B4 - Resultados de pressão interna, velocidade interna e perfil para a caixa sopradora para o modelo semi-empírico com perdas de energia. 99 
LISTA DE ABREVIATURAS E SIGLAS

$\begin{array}{ll}\text { BSL } & \text { New Baseline k- } \omega \text { Turbulence Model } \\ \text { CFD } & \text { Computational Fluid Dynamics } \\ \text { LES } & \text { Large Eddy Simulation } \\ \text { MVF } & \text { Método dos volumes finitos } \\ \text { RANS } & \text { Reynolds Averaged Navier-Stokes } \\ \text { SND } & \text { Simulação numérica direta } \\ \text { SST } & \text { Shear Stress Transport }\end{array}$


unidade

C

Comprimento da caixa sopradora

[m]

cu Constante de modelo, empírica.

D Dimensão característica.

[m]

d

Largura da folha.

[m]

Frequência.

$[1 / \mathrm{s}]$

Aceleração da gravidade.

$\left[\mathrm{m} / \mathrm{s}^{2}\right]$

Altura.

[m]

k

Energia cinética da turbulência

kL Função de correlação.

$\mathrm{L}$

Largura da caixa sopradora.

[m]

$\mathrm{m}$

Massa da folha por unidade de largura.

$[\mathrm{kg} / \mathrm{m}]$

P Pressão.

$[\mathrm{Pa}]$

Re Número de Reynolds.

$S \quad$ Termo fonte.

T Tração na folha.

$[\mathrm{N} / \mathrm{m}]$

$\mathrm{T}_{\mathrm{j}} \quad$ Temperatura de jato de ar impingido.

$\left[{ }^{\circ} \mathrm{C}\right]$

Velocidade instantânea (dir. X).

$[\mathrm{m} / \mathrm{s}]$

u' Componente flutuante de u.

Vetor velocidade.

$\mathrm{U} \quad$ Componente média de u.

$U_{\mathrm{w}} \quad$ Velocidade crítica para o início da vibração da folha. [m/s]

Velocidade instantânea (dir. Y).

Componente média de $\mathrm{w}$. instantânea (dir. Z).

w' Componente flutuante de w.

y Distância da parede.

y+ Distância normalizada à parede. 
sopradora.

$\Gamma \quad$ Coeficiente de difusividade.

$\varepsilon \quad$ Taxa de dissipação da turbulência.

$\zeta \quad$ Fator de perda de energia.

$\mu \quad$ Viscosidade dinâmica. [Pa.s]

$\checkmark \quad$ Viscosidade cinemática. $\quad\left[\mathrm{m}^{2} / \mathrm{s}\right]$

vt Viscosidade turbulenta. -

$\rho \quad$ Massa específica. $\quad\left[\mathrm{kg} / \mathrm{m}^{3}\right]$

$\phi \quad$ Propriedade transportada.

$\omega \quad$ Velocidade angular, dissipação por unidade de

$[\mathrm{rad} / \mathrm{s}]$ energia cinética turbulenta. 


\section{Sumário}

1. INTRODUÇÃO ………………………………………………1

2. OBJETIVOS ………………………………………………

3. DESCRIÇÃO DAS MÁQUINAS PARA PRODUÇÃO DE PAPEL E

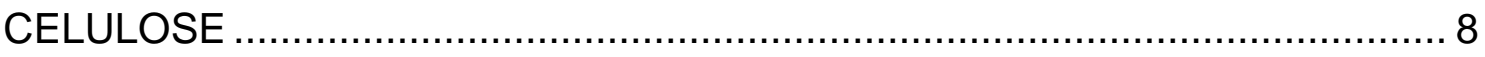

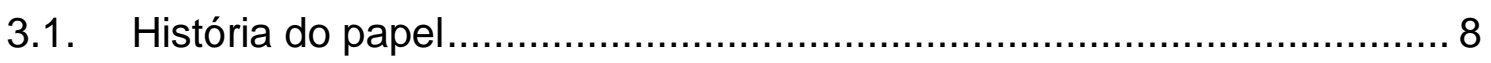

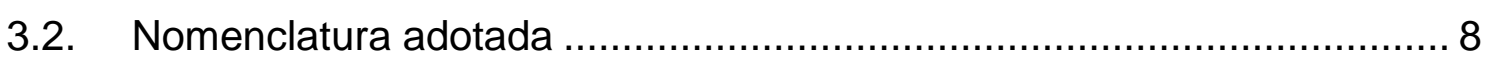

3.3. Classificação das máquinas de fabricação de papel. .............................. 9

3.3.1. Máquinas de fabricação de papel comum …………………............... 9

3.3.2. Máquinas de fabricação de papel tissue............................................. 10

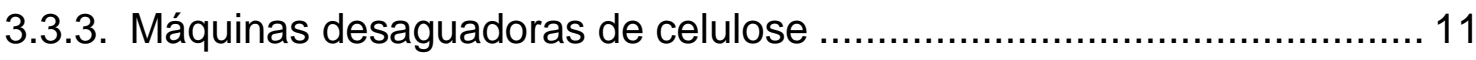

3.4. Seções de uma máquina de fabricação papel ou desaguadora de

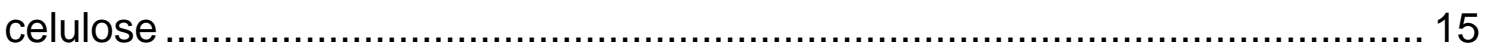

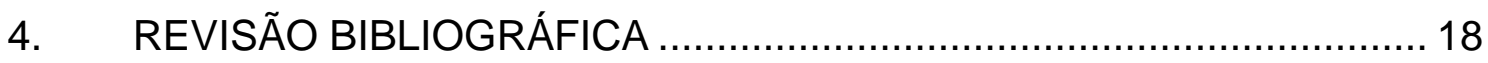

4.1. Sistemas de secagem das máquinas desaguadoras de celulose ......... 18

4.2. Os equipamentos de secagem nas máquinas desaguadoras de celulose 21

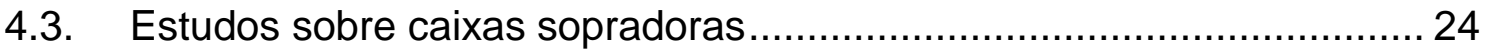

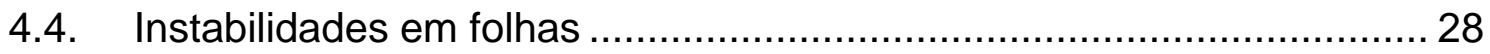

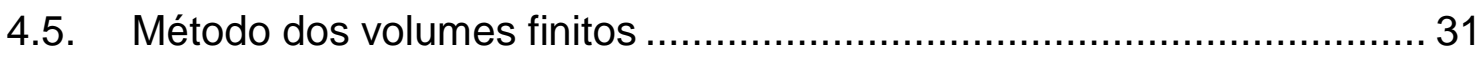

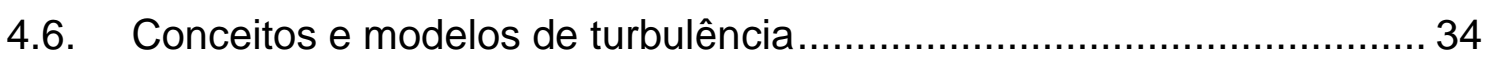

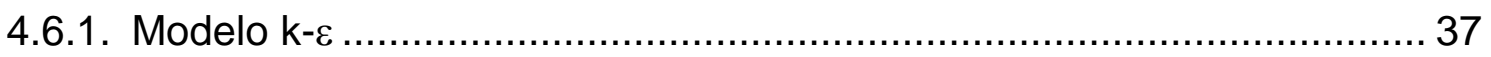

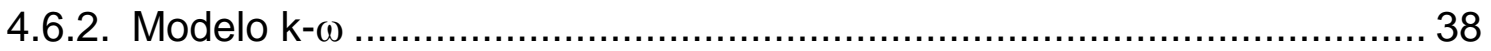

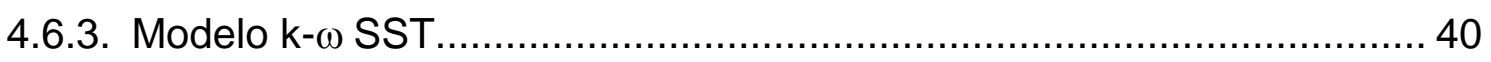

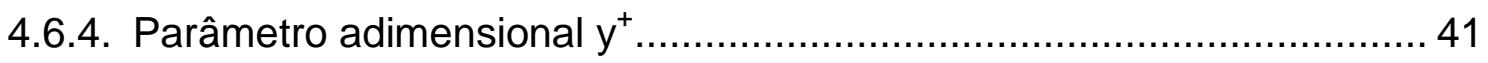

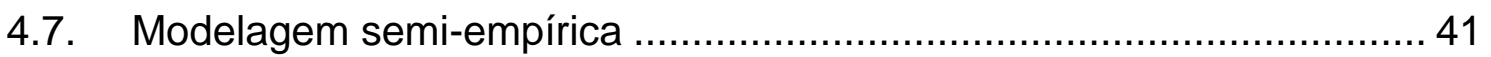

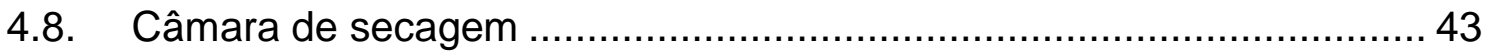

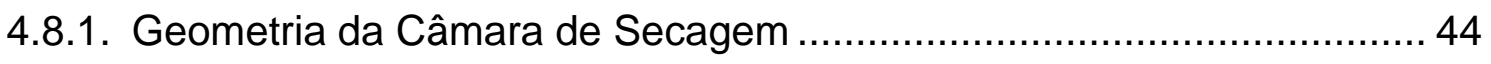

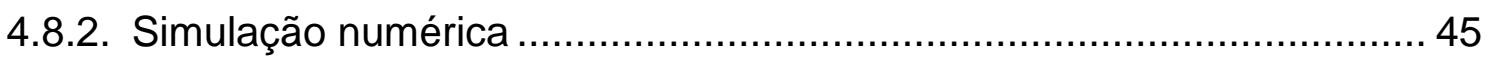

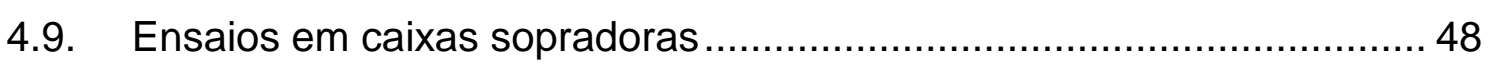

5. METODOLOGIA E DEFINIÇÕES DOS MODELOS …......................... 51 


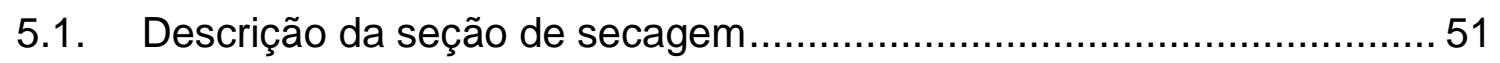

5.2. Geometria das caixas sopradoras modeladas ................................... 52

5.2.1. Caixa sopradora de seção transversal uniforme ................................. 52

5.2.2. Caixa sopradora de seção transversal variável ................................... 54

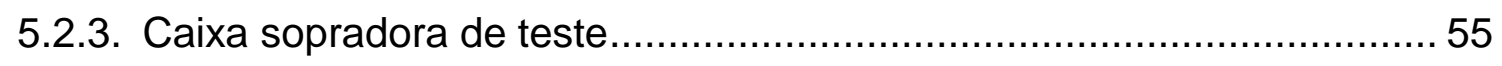

5.3. Aplicação dos métodos de simulação numérica.................................... 56

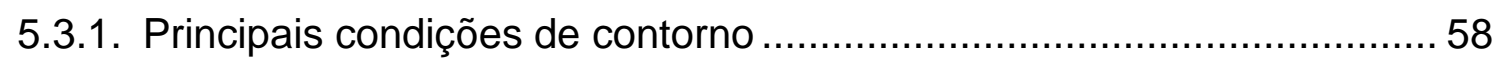

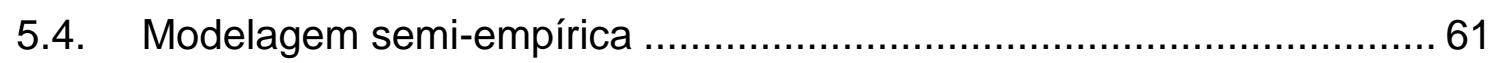

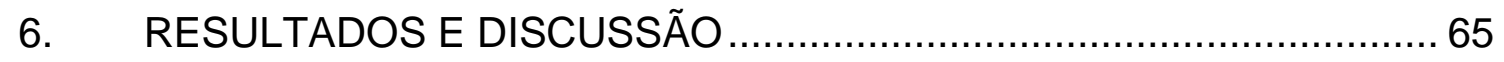

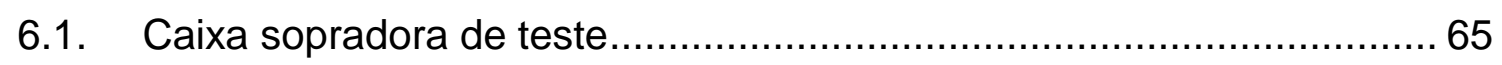

6.2. Caixa sopradora de seção transversal uniforme ………….................. 69

6.3. Caixa sopradora de seção transversal variável ..................................... 76

6.4. Resultados do modelo semi-empírico................................................ 82

6.4.1. Modelo semi-empírico - sem perdas.................................................. 83

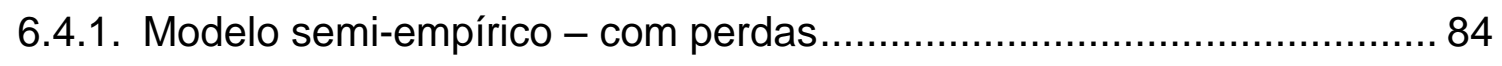

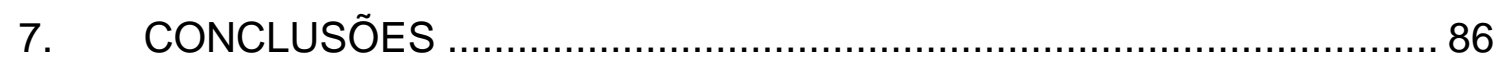

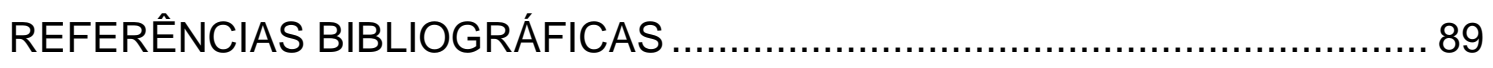

APÊNDICE A - RESULTADOS NUMÉRICOS.............................................. 91

APÊNDICE B - RESULTADOS MODELO SEMI-EMPÍRICO .......................... 96 


\section{INTRODUÇÃO}

Nos processos industriais, assim como em todas as áreas do desenvolvimento, cada vez mais a melhoria dos processos é almejada. Processos que devem garantir máximos rendimentos em quesitos como eficiência energética e produtividade.

A necessidade de se encontrar processos com maior eficiência energética tem raízes nas discussões ambientais, que avaliam os impactos causados ao meio ambiente para que a energia necessária aos processos industriais seja obtida.

Um custo energético relevante na indústria é o da movimentação de gases pro meio de ventiladores, sopradores ou compressores. Existem muitos processos industriais e instalações comerciais que realizam a movimentação de gases através de dutos com diferentes finalidades.

Uma das aplicações possíveis para o escoamento em dutos é o processo de secagem de materiais como, por exemplo, para o processo de produção de celulose. Nas máquinas desaguadoras de celulose o processo de produção ocorre em etapas, desde a preparação de uma mistura de madeira até a obtenção das placas de celulose. Por serem processos contínuos, comumente chega-se a produzir mais de mil toneladas de celulose por dia.

O processo de produção das placas de celulose envolve principalmente a secagem da massa inicial de celulose, que ocorre nas seções de formação, prensa e secagem que compõe esse tipo de máquina.

Inicialmente, uma massa de celulose é formada sendo basicamente composta por água e pequenas quantidades de fibra de celulose. Pode-se dizer que inicialmente temos cerca de $99 \%$ de água $1 \%$ de fibra.

Na primeira parte da máquina desaguadora de celulose localiza-se a chamada seção de formação. Nessa seção, a massa inicial passa por um processo de extração de água, por ação da gravidade e de vácuo. 
Posteriormente, a massa é lançada sobre uma manta semipermeável que contém sob sua extensão caixas a vácuo, que tem como função a extração dessa quantidade inicial de água contida na massa.

Em seguida a folha de celulose, que ainda apresenta cerca de $70 \%$ de água em sua composição, é prensada, no que é conhecido como seção de prensas da máquina. Nessa seção dois rolos criam uma força de prensagem sobre a folha de celulose, quando esta passa entre esses rolos. Alguns tipos de máquina podem ter mais de uma prensagem, e no interior desses rolos a pressão manométrica é negativa para aumentar a eficiência de secagem.

Ao final desta seção, comumente, a folha de celulose contém cerca de $40 \%$ de água em sua composição.

A principal seção, em termos de consumo energético, é a seção de secagem, na qual o processo ocorre por meio de insuflação de ar contra a folha de celulose por meio de duto de ar com múltiplas saídas, identificado nas máquinas de fabricação de papel e de celulose como caixas sopradoras. As caixas sopradoras são, basicamente, paralelepípedos ocos que contém uma face aberta, por onde ocorre a entrada do ar na caixa, e que em uma de suas faces, perpendicular à face de entrada do ar, estão presentes centenas de orifícios.

Nessa etapa a folha de celulose percorre um extenso caminho, muitas vezes superior a cem metros, num ambiente a alta temperatura, normalmente entre $80^{\circ} \mathrm{C}$ à $110^{\circ} \mathrm{C}$, sendo a folha durante todo esse percurso atingida por jatos de ar também quentes, provenientes das caixas sopradoras. Ao final do processo de secagem a folha de celulose contém cerca de $10 \%$ de água em sua composição (Bracelpa, 2013).

A importância de estudar o escoamento de ar nas caixas sopradoras está também relacionada com a expressiva quantidade destes elementos em uma máquina de fabricação de papel, ou de celulose. A título de exemplo uma única máquina desaguadora de celulose pode conter 60 câmaras de secagem cada uma delas com 200 caixas sopradoras, totalizando 4000 condutos de ar aquecido, cada um deles com 275 orifícios. 
O consumo de energia envolvido no processo de secagem é extremamente alto, cerca de $3,4 \%$ de toda energia consumida no mundo refere-se a energia gasta para a produção de papel e celulose (U.S Energy Information Administration, 2013), dando à essa indústria o 50 lugar mundial em consumo de energia, portanto, estudos que visem melhorar utilização desse consumo são importantes. Assim a viabilidade desse estudo tem relação direta com as buscas de soluções, que possam auxiliar de maneira significativa à redução do consumo energético.

Estudar o escoamento de ar nesses dutos com múltiplas saídas é de grande relevância, pois por meio de alterações simples é possível obter alternativas para a diminuição do consumo de energia do processo. Essas alterações podem, por exemplo, ser relacionadas com a variação de características geométricas, como: a quantidade e posicionamento das saídas de ar e a uniformidade da velocidade de saída dos jatos de ar de uma caixa sopradora.

Outra relevância se refere ao escoamento de ar dentro das caixas sopradoras refere-se à manutenção da estabilidade da folha quando do impingimento de ar contra sua superfície, pois durante o processo de secagem de celulose a folha mantem-se durante um percurso de 10 a 20 metros (para um secador vertical) sem suporte durante seu movimento vertical.

Estudos como os de Chang (1991) já demonstraram como a estabilidade do movimento filmes finos, como no caso de uma folha de celulose, é sensível a pequenas variações nas velocidades do ar, tanto se impingido contra a folha quanto se transversal ao seu movimento.

Desta maneira, adota-se como critério neste trabalho que a caixa sopradora, ainda que atenda aos limites de velocidades médias para os jatos de ar deve prover a menor variação possível nessas velocidades para que problemas relacionados ao drapejamento (do inglês fluttering) ocorram durante o processo de secagem da folha de celulose.

Com o desenvolvimento computacional e tecnológico cada vez mais avançados como, por exemplo, e de tecnologias que permitem processamento 
em paralelo, problemas matemáticos mais complexos tornam-se possíveis de serem resolvidos numericamente. Os desenvolvimentos em fluidodinâmica computacional ou CFD (do inglês Computational Fluid Dynamic) apresentam ferramentas capazes de reproduzir numericamente os fenômenos de transportes para escoamentos em amplo espectro de domínios e com as mais diversas características.

Para tanto, existem programas de computador, como o ANSYS CFX, desenvolvidos para o estabelecimento de geometria, geração de malha, préprocessamento, processamento e a visualização dos resultados. 


\section{OBJETIVOS}

O objetivo geral deste trabalho é estudar o comportamento do escoamento de ar no interior de dutos com múltiplas saídas, identificados como caixas sopradoras, existentes em máquinas desaguadoras de celulose. Pretende-se determinar os valores e padrões para a velocidade do ar nas múltiplas saídas das caixas sopradoras de modo que este escoamento produza resultados adequados para a secagem e movimentação estável do produto nas máquinas desaguadoras de celulose.

Os objetivos específicos do trabalho são:

- Estabelecer dimensões, e características geométricas para duto de múltiplas saídas, ou seja, para as caixas sopradoras, através das quais ocorre o escoamento de ar aquecido. Propor e avaliar alternativas geométricas e dimensionais de caixas sopradoras de modo a atender as condições de velocidade do ar nos jatos de saída de ar.

- Definir parâmetros relacionados ao ar aquecido, como suas propriedades físicas. Estabelecer, também, valores para o escoamento de ar, que são dados de entrada para o estudo, como vazão mássica, e pressões na região externa à caixa.

- Fazer a simulação numérica do escoamento nas caixas sopradoras, com detalhamento para as regiões de maior relevância, especialmente os jatos nas saídas. Estabelecer os parâmetros para definição de malhas nas diferentes regiões de escoamento, condições de contorno, modelos de turbulência de modo a atender os requisitos para que os resultados da simulação sejam coerentes com valores testados. Validar a simulação numérica e seus resultados, através de comparação com resultados experimentais conhecidos. 
- Investigar e propor estudo numérico através de modelo semi-empírico, que adota equações integrais para o escoamento e valores de coeficientes de perda obtidos experimentalmente e publicados.

- Tratar e analisar resultados obtidos através da simulação numérica, e do estudo numérico semi-empírico para velocidades médias em orifícios de caixas sopradoras definidas pelas diferentes alternativas, considerando alterações de geometria e de vazão mássica do ar.

Para o desenvolvimento dos objetivos específicos com aplicação da metodologia detalhada no capítulo 5 deste texto são considerados os seguintes parâmetros:

Geometria das caixas sopradoras;

- $\quad$ Comprimento da caixa (C);

- $\quad$ Largura da caixa (L);

- $\quad$ Altura da caixa (h);

- $\quad$ Ângulo de variação para a largura ( $\beta$ );

- Diâmetro dos orifícios de saída da caixa;

- Disposição dos orifícios de saída da caixa.

Estado do ar;

- Temperatura;

- Massa específica.

Velocidade do ar;

- Internamente à caixa;

- Velocidade nos orifícios de saída da caixa.

Pressão do ar

- $\quad$ Pressões internas à caixa;

- Pressões externas à caixa; 
Para os quais são comparadas as uniformidades da velocidade nos orifícios de saída da mesma.

Em termos quantitativos, a meta a ser atingida é que a variação do valor da velocidade média de cada um dos jatos, provenientes dos orifícios de uma caixa sopradora, deve ser inferior a $3 \%$ da média das velocidades médias (Voith Paper, 2011), diminui o custo de energia do processo de secagem. Portanto esse parâmetro é utilizado como referência para aceitação ou não e propostas alternativas das caixas sopradoras neste estudado.

Um requisito também considerado neste trabalho para definir as alternativas geométricas ou dimensionais para novas caixas sopradoras, é que estas alternativas resultem no menor impacto possível em termos de complexidade para sua fabricação, pois isso levaria ao aumento de custo da unidade da caixa sopradora e tempo necessário para sua fabricação. 


\section{DESCRIÇÃO DAS MÁQUINAS PARA PRODUÇÃO DE PAPEL E CELULOSE}

\subsection{História do papel}

O primeiro processo autêntico de fabricação de papel que se tem notícia vem da China e data de aproximadamente 105 a.C. A ideia base era a de se dissolver pedaços de madeira de amoreira e trapos de roupas velhas, obtendo fibras e depois reagrupando-as, formando uma folha que era seca ao sol.

Com as invasões muçulmanas 850 anos mais tarde, o processo de fabricação deixou de ser um segredo do povo chinês e logo se espalhou pela Europa. Durante os séculos seguintes o processo foi sendo desenvolvido até chegar a um capaz de produzir uma "folha infinita", em 1799.

O processo contínuo trouxe uma nova dimensão e importância ao mundo papeleiro e gráfico, diversificando sua utilização e sua fabricação, surgindo guardanapos, toalhas, entre outros. A partir disto ocorreu uma evolução bastante significativa no modo de vida das pessoas.

\subsection{Nomenclatura adotada}

Para facilitar a compreensão do texto, foi adotada nomenclatura específica para as máquinas e equipamentos, conforme a seguir:

- Máquinas de fabricação de papel: são as máquinas que têm por objetivo a produção do papel como produto final, em quaisquer de seus tipos;

- Máquinas desaguadoras de celulose: são máquinas que têm por objetivo a produção de placas de celulose que são utilizadas para a fabricação de papel; 
- Seção de secagem: é uma das seções que compõe a máquina de fabricação de papel ou a desaguadora de celulose;

- Câmara de secagem: é uma subdivisão da seção de secagem das máquinas desaguadoras de celulose. Ela é um espaço, fisicamente confinado, onde encontramos um ou mais ventiladores. Elas distribuem o ar aquecido para as centenas de caixas sopradoras;

- Caixas sopradoras: são dutos de múltiplas saídas, em forma de paralelepípedo no qual uma de suas faces está conectada à câmara de secagem (face de alimentação da caixa sopradora). As múltiplas saídas produzem centenas de jatos de ar que são impingidos contra a folha de celulose secando-a.

\subsection{Classificação das máquinas de fabricação de papel.}

Existem várias maneiras de classificar estas máquinas. Neste trabalho sugere-se a classificação pela sua seção de secagem. Assim os tipos básicos de equipamentos existentes são:

- Máquinas de fabricação de papel comum, da qual se excluem as que fabricam papel do tipo tissue;

- Máquinas de fabricação de papel tissue;

- Máquinas desaguadoras de celulose.

\subsubsection{Máquinas de fabricação de papel comum}

Máquinas de fabricação de papel comum são responsáveis pela fabricação de diversos tipos de papéis existentes, desde os papéis do tipo marrom (por exemplo, o papelão), que têm por principal característica ser capaz de suportar valores elevados de tensão, aos papéis tipo gráfico que usamos diariamente para fazer impressões ou que encontramos em revistas. 
Nestas máquinas, a seção de secagem é composta por uma série de cilindros secadores, nos quais o papel é aquecido e gradativamente secado. A Figura 1 apresenta um exemplo de seção de secagem desse tipo de máquina, no qual se pode observar que o papel (linha tracejada) percorre uma sequência de cilindros secadores (em amarelo).

Nesse tipo de seção de secagem é comum existirem cerca de 20 a 50 cilindros secadores. Tais cilindros têm diâmetros de cerca de 2 metros e 0 comprimento dessa seção de secagem chega normalmente a mais de 150 metros.

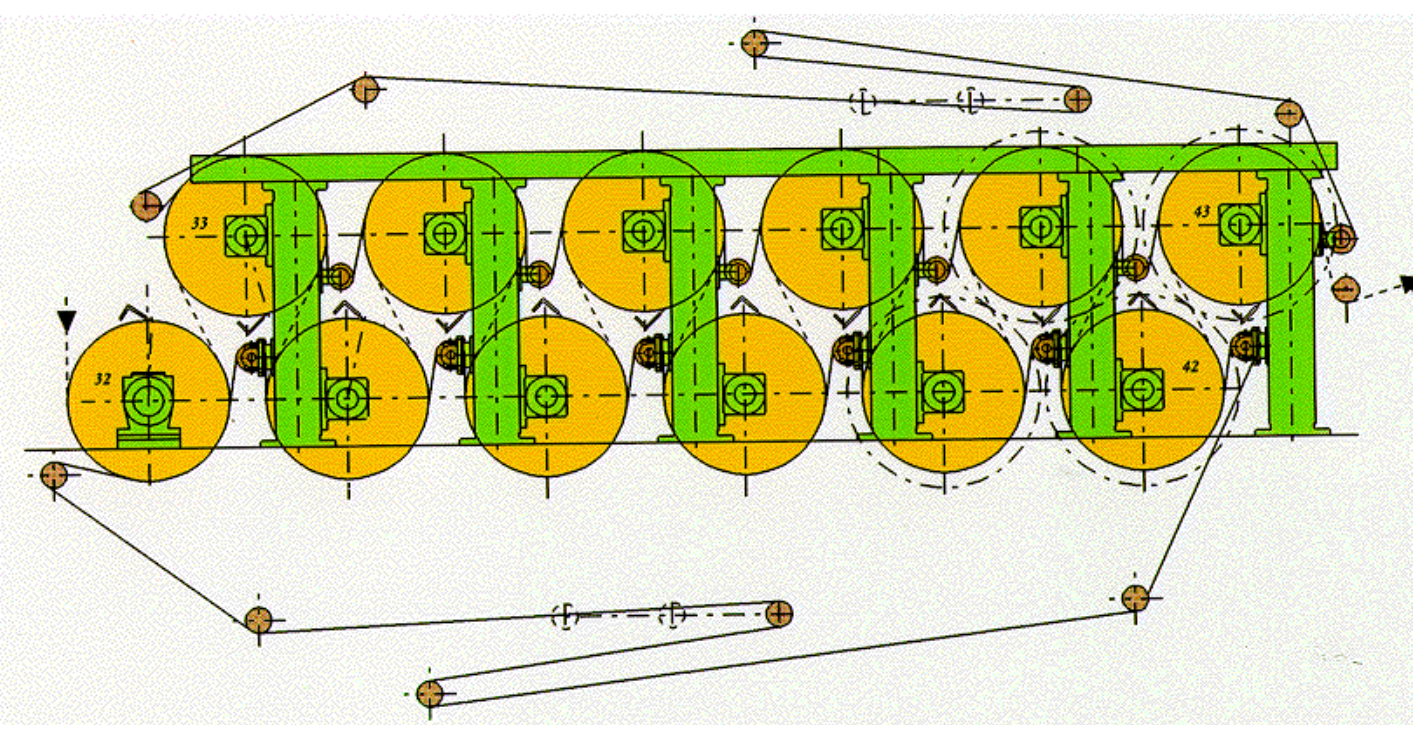

Figura 1 - Exemplo seção de secagem de uma máquina de papel (Voith Paper, 2011).

\subsubsection{Máquinas de fabricação de papel tissue}

São as máquinas responsáveis pela fabricação de papéis tipo tissue. Esse tipo de papel tem por principal característica ser capaz de absorver grandes quantidades de água. Dentre os exemplos aplicação deste tipo de papel, têm-se os papeis toalha, papeis higiênicos, papeis lenços, entre outros. 
Nesse tipo de máquina a seção de secagem corresponde à região onde se encontra o único rolo secador da máquina, este rolo é denominado de cilindro Yankee. A Figura 2 mostra uma seção de secagem típica de uma máquina tissue. $\mathrm{O}$ cilindro Yankee normalmente tem normalmente entre 3 e 5 metros de diâmetro, e ao contrario das demais máquinas de papel a seção de secagem das máquinas tissue tem pequeno comprimento.

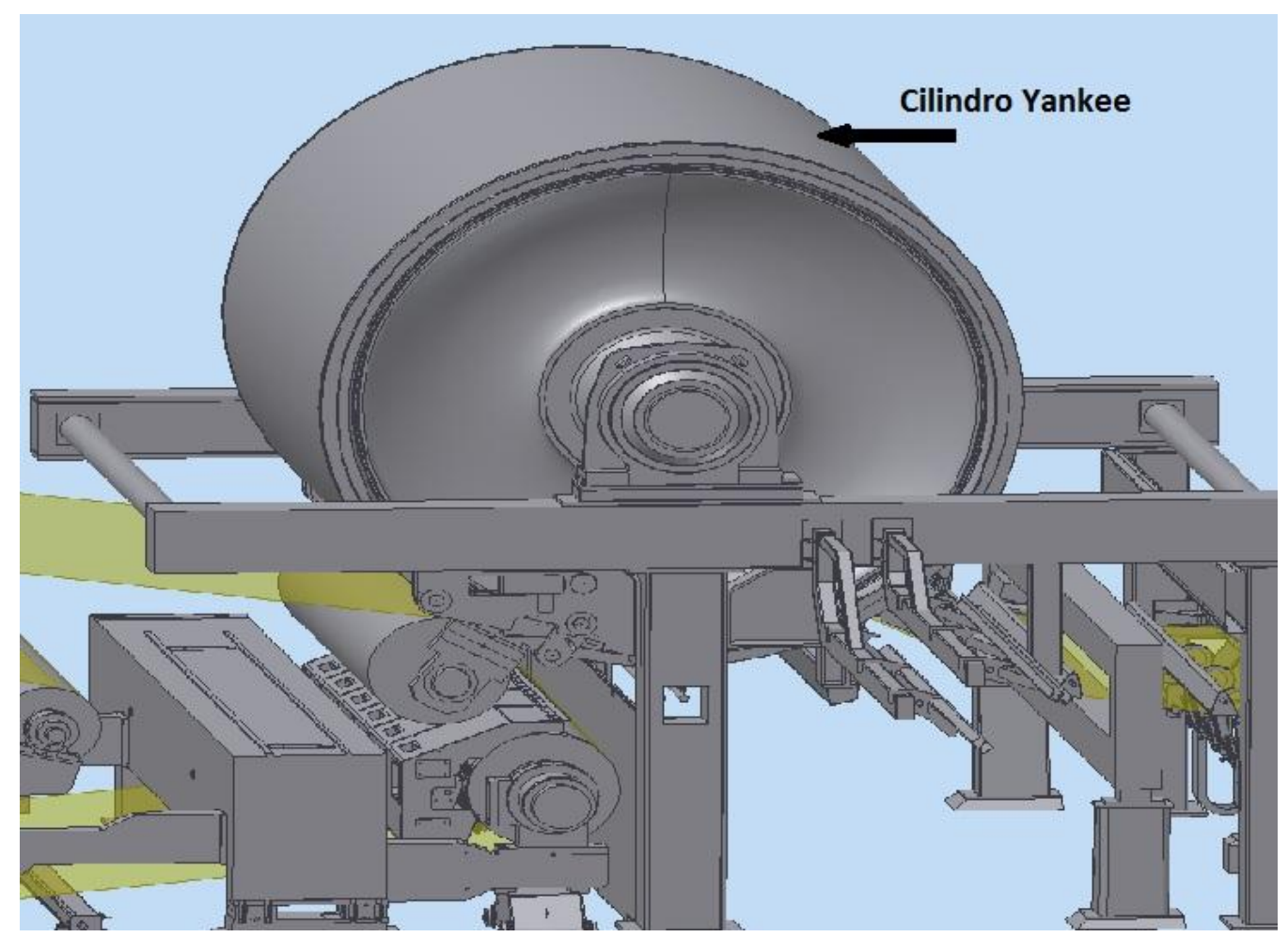

Figura 2 - Exemplo de seção de secagem de uma máquina de papel tissue (Voith Paper 2011).

\subsubsection{Máquinas desaguadoras de celulose}

A grande diferença entre uma máquina de fabricação de papel e uma máquina desaguadora de celulose é o produto final gerado por estes tipos de máquinas. Enquanto numa máquina de fabricação de papel o produto final já é um produto acabado, na desaguadora de celulose o objetivo é a produção de "placas" de celulose. Essas placas são insumos de produção para máquinas de papel. Cabe ressaltar que muitas máquinas de papel não se utilizam diretamente desse tipo de insumo, ou por terem controle do processo de 
fabricação do papel desde a extração da madeira, ou por usarem como insumo outras fontes de celulose, como no caso das máquinas que fabricam papéis reciclados.

Nas máquinas desaguadoras de celulose o processo de secagem, que acontece na seção de secagem, ocorre através da insuflação de ar através dos orifícios de dutos com múltiplas saídas, chamados de caixas sopradoras. Estes dutos ficam dispostos horizontalmente (acima e abaixo da folha de celulose) ou verticalmente (aos lados da folha de celulose).

Este trabalho se aterá à seção de secagem das máquinas do tipo desaguadoras de celulose, mais especificamente ao escoamento de ar dentro dessas caixas sopradoras.

Um exemplo de arranjo horizontal dessas caixas são os secadores tipo flakt dryers, nos quais a folha de celulose percorre distâncias de até sessenta metros horizontalmente durante as várias passagens que a folha de celulose atravessará (Metso Paper 2002).

A Figura 3 apresenta um exemplo de disposição dos rolos que guiarão a folha nesse percurso.

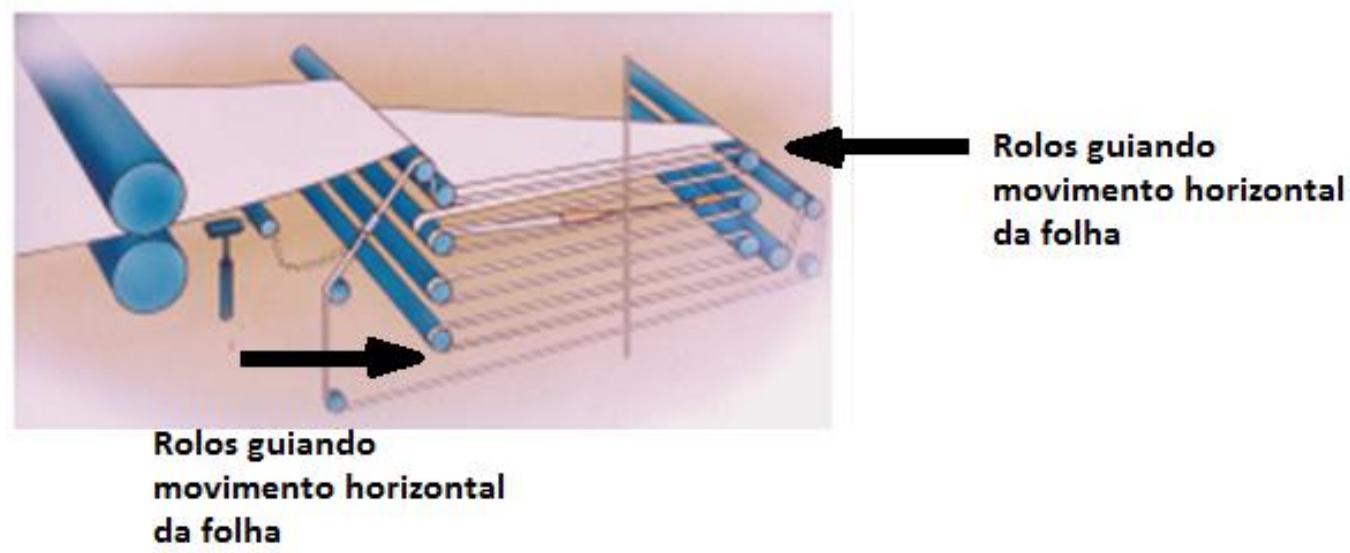

Figura 3 - Leiaute básico de um flakt dryer (Andritz 2010).

Durante esse percurso, entre os rolos que guiam o movimento da folha de celulose, encontram-se as caixas sopradoras. A Figura 4 mostra uma pequena parte desse caminho percorrido pela folha de celulose (Metso Paper 2002). 


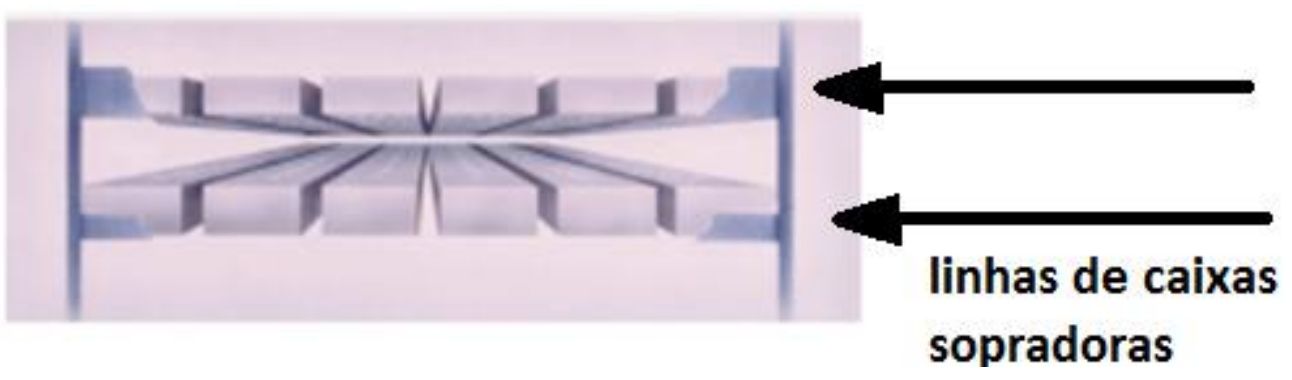

Figura 4 - Posicionamento das caixas sopradoras durante a passagem da folha de celulose (Andritz 2010).

A Figura 5 mostra um exemplo de uma máquina desaguadora onde existem mais de 10.000 caixas sopradoras. Nessa figura podemos observar apenas a seção de secagem de uma máquina desaguadora de celulose (região amarela). As caixas sopradoras encontram-se distribuídas em toda essa seção, conforme detalhado acima.

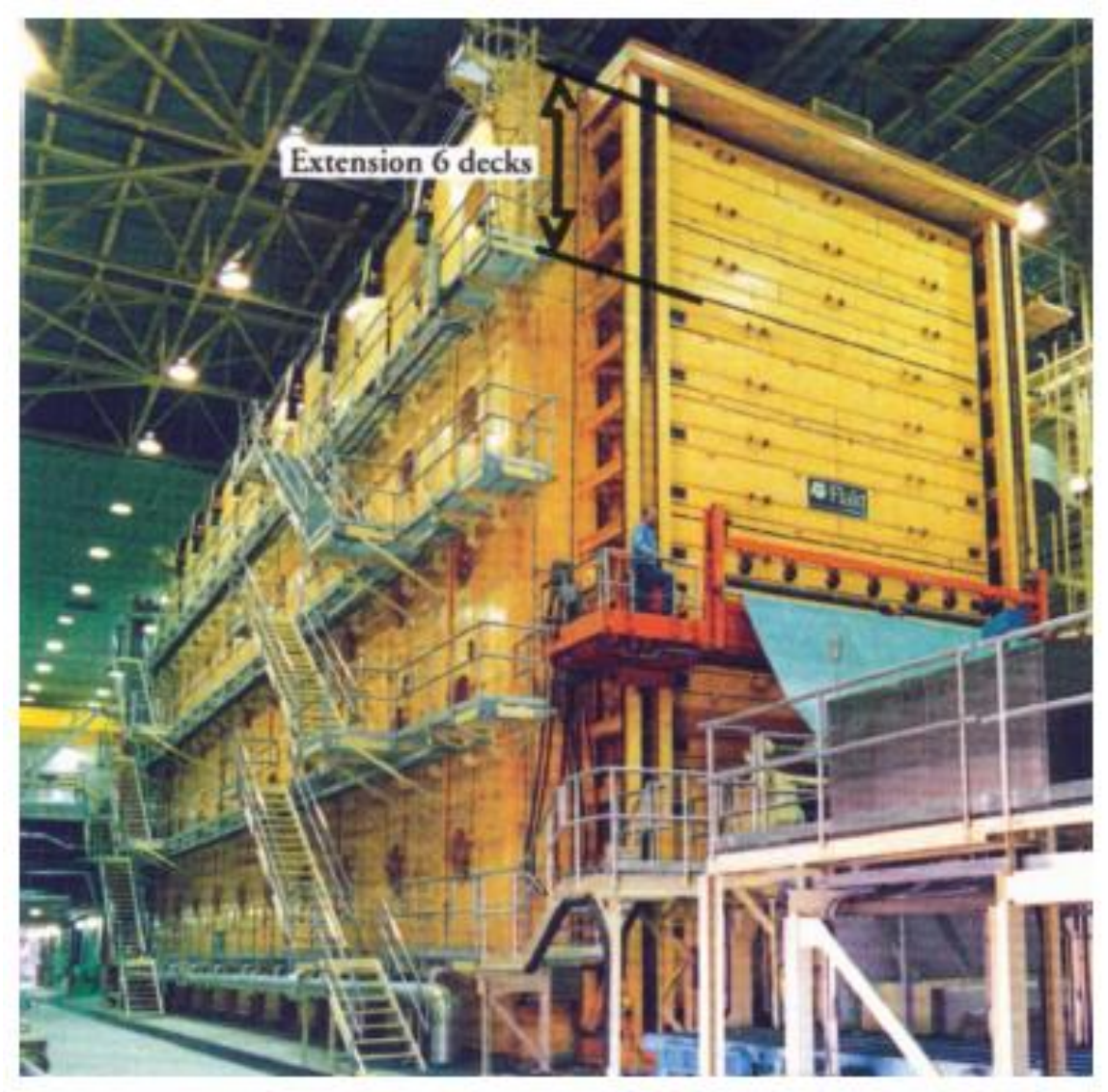

Figura 5 - Exemplo de seção de secagem de máquina desaguadora de celulose (Andritz, 2010). 
De maneira análoga ocorre o processo de secagem da folha de celulose em secadores do tipo vertical. A principal diferença é a disposição dos rolos que guiam o movimento. No caso do secador vertical os rolos guiam o movimento no sentido vertical e as caixas sopradoras ao invés de estarem acima e abaixo da folha de celulose ficam aos lados da mesma.

Em seu arranjo vertical, a seção de secagem apresentará dezenas de caixas sopradoras dispostas verticalmente. Por razões obviamente relacionadas ao custo construtivo, não é possível construir uma seção de secagem de dimensões verticais tão grandes que possam garantir que em apenas um movimento de subida ou descida da folha, esta fique suficientemente seca.

Portanto a folha de celulose, por várias vezes faz esse movimento de subida ou descida passando pelas diversas caixas sopradoras existentes. De maneira análoga o mesmo pode-se dizer do arranjo horizontal das caixas sopradoras. A Figura 6 mostra um exemplo bastante simplificado de uma vista de uma seção de secagem vertical, onde podemos ver o movimento da folha de celulose (linha vermelha), a posição das caixas sopradoras (retângulos pretos) e a direção do jato de ar (linhas horizontais em preto)

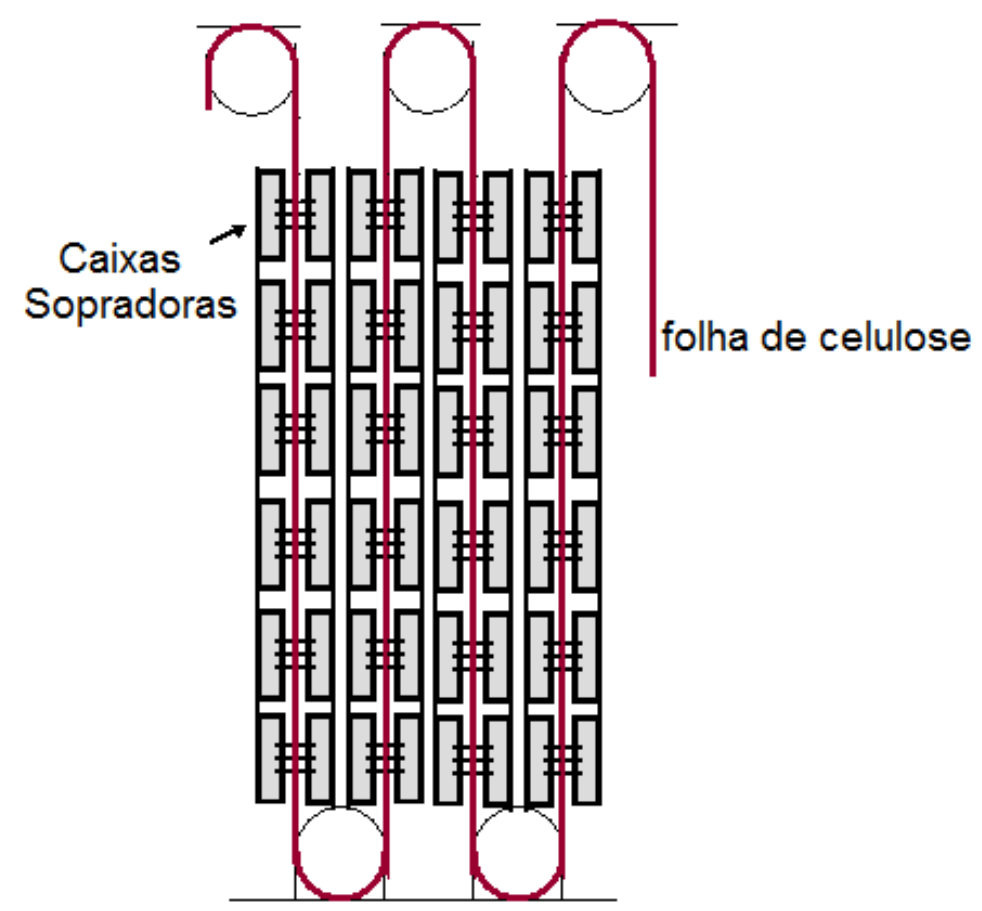

Figura 6 - Exemplo de arranjo vertical de uma seção de secagem de uma máquina desaguadora de celulose. 
Acredita-se que no processo vertical, por diversos motivos, a economia de energia é de até $25 \%$ (Estado de São Paulo, 2010) quando comparado com um secador horizontal de mesmas capacidades produtivas.

Neste projeto será analisado o comportamento do escoamento de ar dentro desses dutos com múltiplas saídas apenas para o modelo de secador vertical.

A quantidade de caixas sopradoras presentes numa seção de secagem pode passar das dezenas de milhares, dessa maneira, levando-se em consideração que o tempo de execução de projetos é um dos principais fatores para a decisão de compra de uma máquina desaguadora de celulose, a geometria destas caixas sopradoras deverá ser de simples fabricação.

\subsection{Seções de uma máquina de fabricação papel ou desaguadora de celulose}

Os diversos tipos de máquinas de fabricação de papel ou desaguadoras de celulose apresentam basicamente a mesma sequência de etapas para a produção de papel ou celulose. Atualmente uma máquina de fabricação de papel possui, de forma geral, o leiaute exibido na Figura 7.

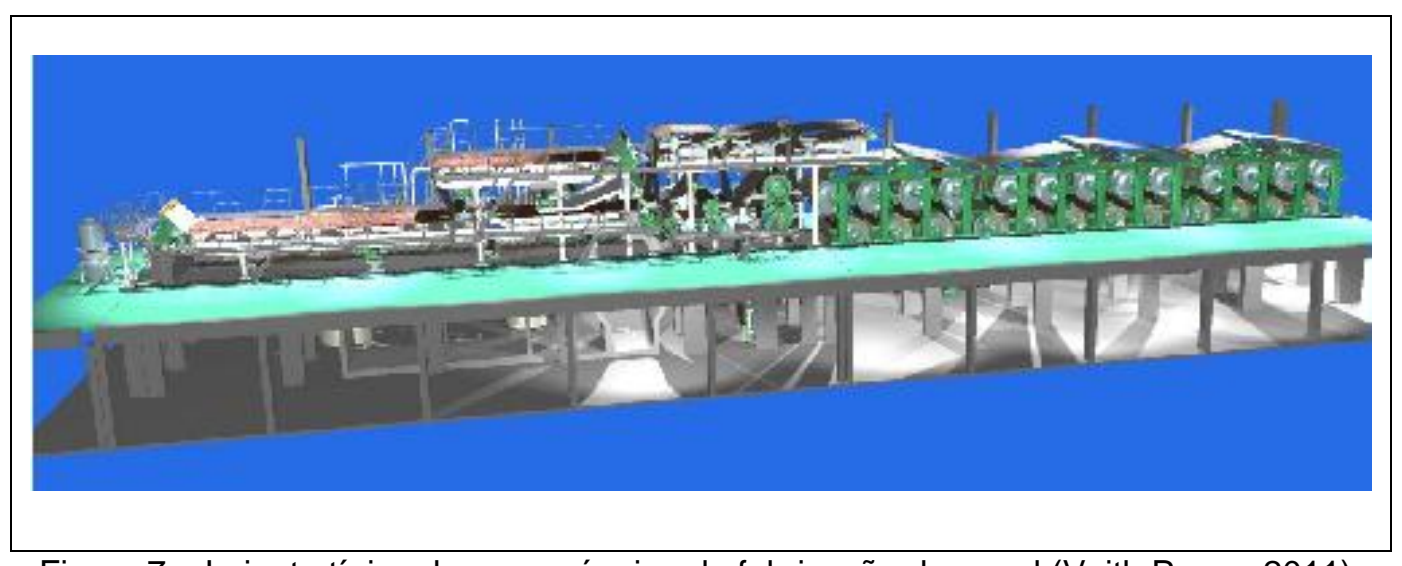

Figura 7 - Leiaute típico de uma máquina de fabricação de papel (Voith Paper, 2011). 
As principais partes de uma máquina de papel ou de uma desaguadora de celulose são:

- $\quad$ Caixa de entrada;

- Seção de formação;

- Seção prensas;

- Seção de Secagem;

- Aplicadores;

- Calandra;

- Enroladeira.

Para fins de ilustração de algumas das seções existentes numa máquina de papel ou desaguadora de celulose estão representadas na Figura 8 e na Figura 9 com seus leiautes típicos.

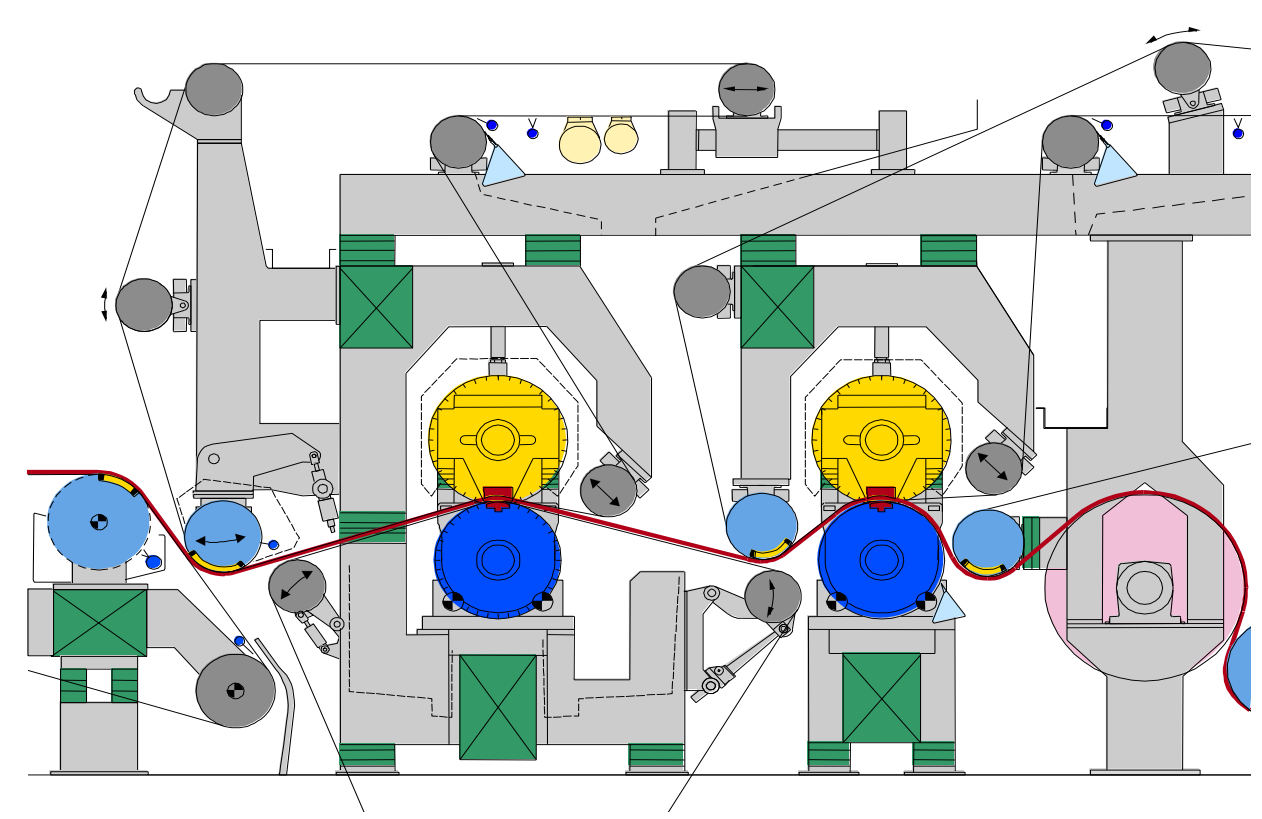

Figura 8 - Seção de prensas (Voith Paper, 2011). 


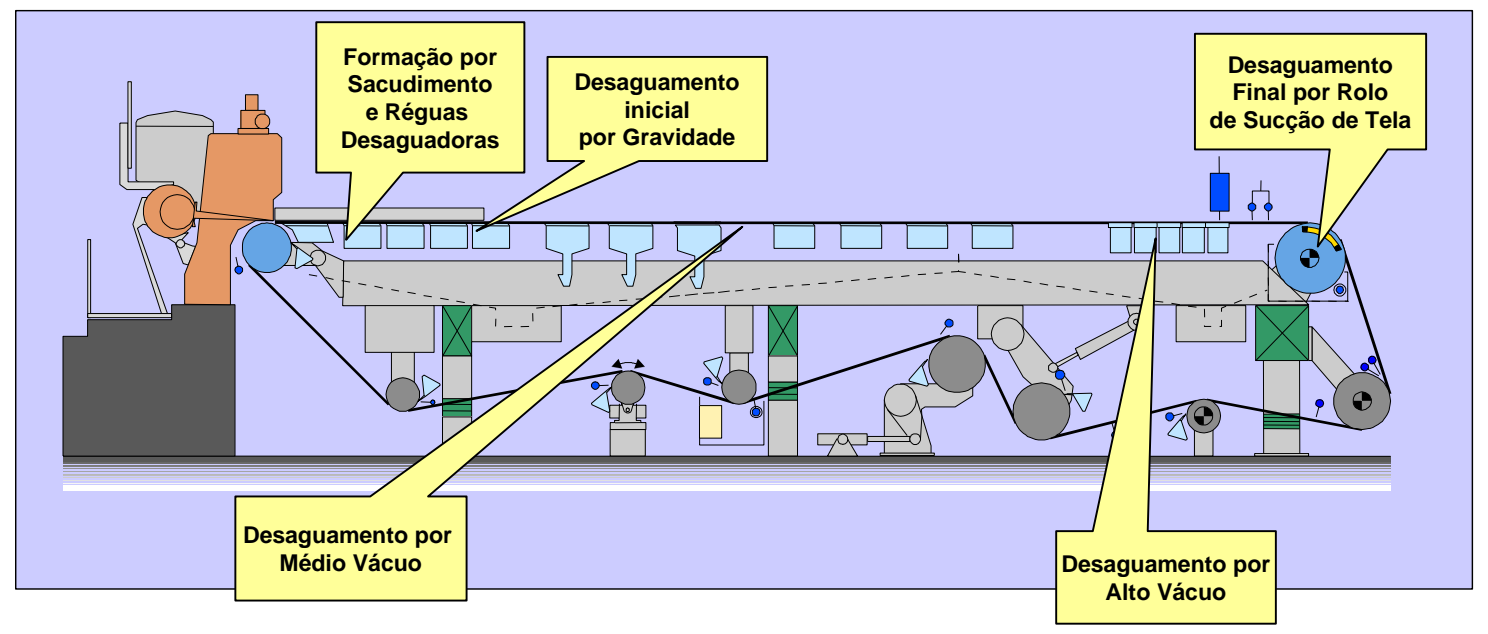

Figura 9 - Seção de formação (Voith Paper, 2011). 


\section{REVISÃO BIBLIOGRÁFICA}

\subsection{Sistemas de secagem das máquinas desaguadoras de celulose}

O processo de secagem é uma etapa de grande relevância para a produção de placas de celulose, bem como para outros tipos de produtos, com destaque para materiais que exigem a aplicação de películas finas de revestimento, como no caso de fitas magnéticas ou filmes fotográficos. Nesses processos a secagem é útil por colaborar na eliminação da umidade presente nas placas de celulose e por garantir da uniformidade da aplicação do revestimento, para o caso das fitas magnéticas.

Na revisão da literatura e no estudo do estado da arte sobre técnicas de secagem de produtos como placas de celulose, papel comum, papel tissue ou fitas magnéticas são encontrados vários processos. Dentre estes o processo de impingimento de ar tratado em condições de umidade e temperatura controladas, tem sido amplamente utilizado.

Conforme apresentado anteriormente, neste trabalho convencionou-se tratar por caixa sopradora, os dutos pelos quais o ar escoa desde a etapa de tratamento até ser impingido contra a superfície que se pretende secar.

O processo de secagem ocorre em um tipo de seção da máquina de fabricação de papel ou celulose, usualmente identificada na literatura por Secador de Flutuação (floatation dryer do inglês) ou por Secador por Impingimento (impingement dryer do inglês), conforme Aust (1997). Esta seção de secagem é comumente dividida em várias zonas ou módulos, como mostrado na Figura 10.

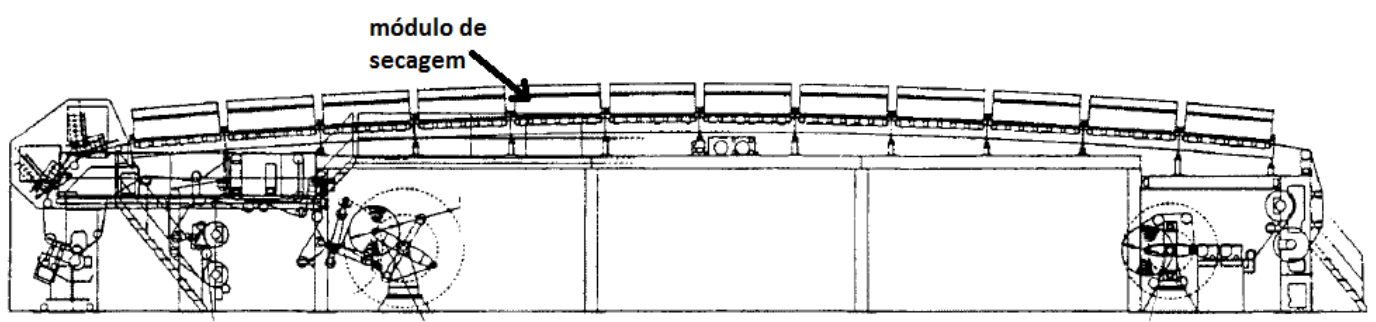


Figura 10 - Seção de secagem para uma planta de fabricação de filmes revestidos (Aust et al. 1997).

Cohen et al. (1995) demonstram que o secador industrial é o equipamento periférico que determina grande parte dos custos envolvidos para a fabricação de produtos revestidos e, portanto, há sempre interesse em estudos que tenham objetivos em minimizar custos que sejam relacionados à ele.

Cohen et al. (1995) e outras análises indicam que a seção de secagem representa a maior parte da planta de uma fábrica de revestimentos ou secagem de celulose. Sendo assim, é a maior responsável tanto pelos custos operacionais, resultantes da energia utilizada no processo de secagem, quanto pelos custos associados à instalação dessas seções.

No contexto de uma análise que procure melhorar a rentabilidade da planta, na qual a seção de secagem está inserida, é destacado que estudos sobre a seção de secagem destas máquinas, analisando sua geometria ou parâmetros de operação relacionados ao escoamento de ar ou às caixas sopradoras, torna-se importante e motiva o foco deste trabalho.

A revisão bibliográfica indicou que determinar experimentalmente as reais condições de funcionamento em um equipamento real é extremamente difícil. A maioria dos parâmetros necessários para caracterizar o processo de secagem, tais como a temperatura no interior da seção de secagem, a concentração de umidade e taxa de evaporação do vapor d'água da folha, que se pretende secar, são difíceis de medir. Uma das razões para esta dificuldade é que os pontos ideais para as medições são de complicado, ou até mesmo proibido, acesso.

A secagem, presente nos mais diversos processos industriais, genericamente, tem por objetivo eliminar um fluido, normalmente no estado líquido e volátil, contido em um corpo não volátil.

No caso da indústria de fabricação de papel e de celulose, o objetivo principal é promover a evaporação da água presente na massa de celulose. Destaca-se que o foco selecionado para o presente estudo está relacionado às máquinas desaguadoras de celulose. Neste caso, o processo de secagem 
utiliza duas técnicas, o fornecimento de calor, para que possa ocorrer evaporação da água, e a existência de um sorvedouro para remover a água, no estado de vapor presente nas superfícies da folha de celulose.

$\mathrm{Na}$ maioria das máquinas de fabricação de celulose o fornecimento de calor é realizado por meio de cilindros aquecidos que estão em contato com a folha de celulose que será seca.

O transporte do vapor de água removido da superfície da folha é realizado pelo ar em movimento fornecido pelo sistema de ventilação. As teorias existentes na secagem procuram fundamentar e modelar os fenômenos do transporte da água do interior do meio sólido até a superfície, conforme apresentado por Metso Paper (1995).

O movimento para a retirada da água do interior da celulose até a sua superfície é relacionado aos mecanismos de transferência de massa, conforme Aust et al. (1997).

Pode-se então dividir o processo em três etapas principais que representam os fenômenos que ocorrem no interior da folha.

Pode-se dividir o processo de secagem em três etapas principais, que representam fenômenos que ocorrem no interior da folha:

- Difusão líquida: Decorrente da presença de gradiente de concentração de água entre camadas do material;

- Difusão de vapor: que é consequência do gradiente de pressão de vapor d'água, que é causado pelo gradiente de temperatura;

- Escoamento de líquido e de vapor: que é proporcionado pela diferença de pressão, de concentração de água entre a folha e o ambiente além dos efeitos de capilaridade.

Assim, considerando os fenômenos apresentados, o processo de secagem está relacionado aos seguintes parâmetros:

- Conteúdo inicial de umidade na folha de celulose;

- Conteúdo final de umidade que a folha pode atingir, que está relacionado com suas características higroscópicas; 
- Modo pelo qual a água está relacionada com a estrutura da folha de celulose;

- Modo pelo qual o transporte da água é feito do interior à superfície da folha.

\subsection{Os equipamentos de secagem nas máquinas desaguadoras de celulose}

Conforme Poirier E Pikulik (2003) verifica-se na evolução do processo de secagem do papel e da celulose, que as primeiras técnicas adotadas utilizavam ar na condição ambiente.

Este procedimento foi utilizado até o desenvolvimento do conceito de cilindros secadores. Esses cilindros são dispostos horizontalmente, normalmente formando duas linhas, o que torna possível que o aquecimento realizado seja alternado em ambos os lados da folha de papel ou de celulose (MUJUMDAR, 1995). A Figura 11 mostra um esquema simplificado do posicionamento de alguns desses cilindros secadores, identificados pelos círculos pretos de maior diâmetro. A folha, que está representada pela linha em vermelho, entra em contato com a superfície dos cilindros em ambos os lados. Os cilindros secadores tem sua temperatura interna mantida entre $70^{\circ} \mathrm{C}$ e $90^{\circ} \mathrm{C}$, por um circuito que introduz neles vapor de água.

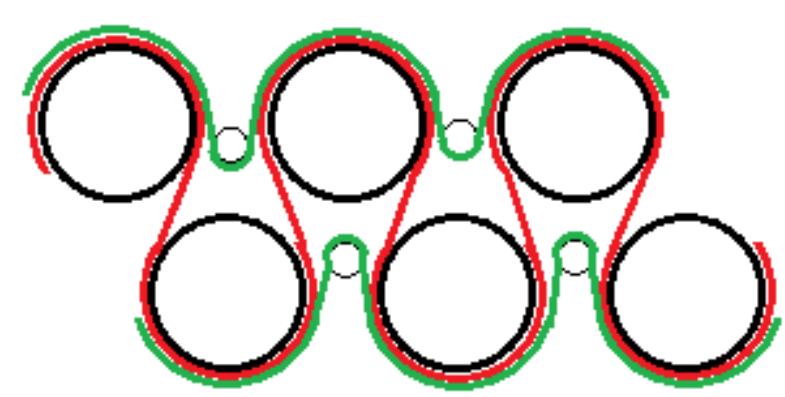

Figura 11 - Esquema simplificado de uma seção de secagem com cilindros secadores. 
Autores como Poirier e Pikulik. (2003) determinaram que para alguns tipos de papel, tais como o papel tipo "Escrever/lmprimir", o processo de secagem deve ser lento, e basear-se no princípio da condução de calor pela folha. Neste caso o papel passa ao redor dos cilindros secadores, conforme mostrado na Figura 11, recebendo calor por contato direto.

Convém ressaltar que no esquema simplificado da Figura 11 pode-se observar a presença de dois elementos, um formado pelos cilindros secadores e folha e outro formado por uma tela, indicado pela linha verde externa, que envolve e guia a folha durante o processo de secagem. Embora não fique em contato com folha durante todo o processo a presença dessa tela ajuda a separar a secagem em quatro diferentes etapas:

- $\quad$ Primeiramente a folha de papel ou de celulose entra em contato com o cilindro secador, porém não fica em contato com a tela de secagem;

- $\quad$ Posteriormente, a folha fica entre a superfície aquecida do cilindro secador e a tela (etapa na qual existe um rápido aquecimento e o inicio do processo de vaporização);

- A terceira etapa é representada pelo trecho que a tela deixa de envolver a folha, provocando uma intensa evaporação;

- Na última etapa, a folha, que já está separada da tela, agora se separara também da superfície do cilindro secador, o que causa seu rápido resfriamento e por consequência há significativa diminuição na evaporação (D'ALMEIDA, 1988).

Apesar da predominância na utilização do sistema de cilindros aquecidos a vapor, existem outras tecnologias de secagem de papel e de celulose, sendo que algumas utilizam ventilação forçada. Dentre estas, há um método importante que se baseia na aplicação de ar denominado "impingement drying", ou secagem por impingimento, que é predominante em máquinas desaguadoras de celulose. Esse método adota aplicação de jatos de ar aquecidos a elevadas temperaturas diretamente sobre a folha de celulose. 
Nas máquinas que utilizam o conceito de secagem por impingimento de ar ocorre um processo praticamente contínuo de aquecimento da folha utilizando ar com baixa umidade relativa. Como apresentado, a umidade é retirada primeiramente do interior da folha e conduzida para a sua superfície. Em seguida a umidade é removida da superfície da folha e transportada por este fluxo de ar promovido pelo sistema de ventilação forçada.

As seções de secagem, presentes em máquinas desaguadoras de celulose, podem adotar diferentes arranjos internos e uma classificação possível está relacionada à posição da folha de celulose. Dois tipos são tratados nesta análise: equipamentos de arranjo horizontal e de arranjo vertical.

Para equipamentos com arranjo horizontal, um exemplo típico são os secadores identificados por flakt dryers (Andritz 2010). Nestes a folha de celulose percorre distâncias de até sessenta metros horizontalmente. Esse tipo de arranjo é o mais comum em máquinas desaguadoras de celulose, nas quais o acabamento superficial não é relevante durante o processo de fabricação.

Convém destacar que a folha de celulose tem espessura maior que os demais tipos de papéis. A folha de celulose pode ter até 3 milímetros de espessura enquanto uma folha de papel do tipo "imprimir" possui espessura de 0,1 milímetros. Como consequência, no processo de secagem, a quantidade de água que deve ser retirada por evaporação é significantemente maior para 0 caso das placas de celulose.

Outra característica inerente ao processo de secagem com arranjo horizontal é que os jatos de ar, provenientes das caixas sopradoras, além de serem utilizados como fornecedores de calor para a folha, deverão também auxiliar na sua sustentação e na sua movimentação horizontal.

Tal característica aumenta a necessidade de fluxo de ar, ou seja, maior vazão nos ventiladores e por consequência ocorre aumento do consumo de vapor que realiza o aquecimento. A ampliação no uso de vapor para manutenção da temperatura de maior vazão de ar insuflado pode ser considerada como uma deficiência no processo, pois exige maior uso de energia, sendo que este acréscimo no consumo de vapor não é utilizado para melhorar a secagem da folha. 


\subsection{Estudos sobre caixas sopradoras}

Uma das principais características presentes nas caixas sopradoras para projetos de secadores horizontais de máquinas desaguadoras de celulose é a presença, além dos jatos incidentes perpendicularmente à folha, de jatos oblíquos à folha (Metso Paper, 1995). Esses jatos oblíquos têm a função de estabilizar a folha de celulose durante seu percurso entre os rolos que guiam seu movimento horizontal. Dessa maneira a tensão necessária para 0 movimento da folha é bastante reduzida (Metso Paper, 1995). A Figura 12 mostra uma representação deste tipo de caixa sopradora.

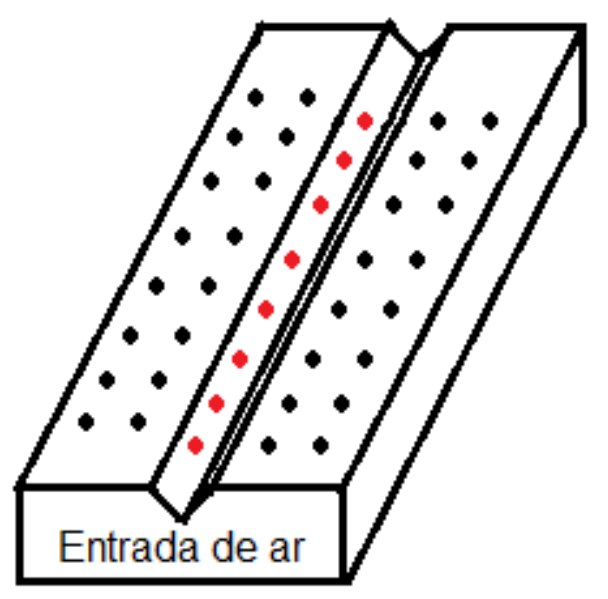

Figura 12 - Caixa sopradora com orifícios oblíquos (vermelho) e perpendiculares (preto).

Embora tenham temperatura igualmente elevada os jatos oblíquos possuem uma menor utilidade de secagem da folha de celulose quando comparado aos jatos perpendiculares que incidem na folha, pois a distância entre os jatos oblíquos e a folha é maior, o que implica numa menor eficiência no processo de secagem.

Dessa maneira pode-se considerar uma vantagem à inexistência desses jatos oblíquos nos projetos das caixas sopradoras de seções de secagem vertical, que são alvo de estudo neste trabalho (Bates 2010). A Figura 13 
mostra um vista frontal do secador horizontal, mostrando o efeito de sustentação provocado pelos jatos oblíquos.

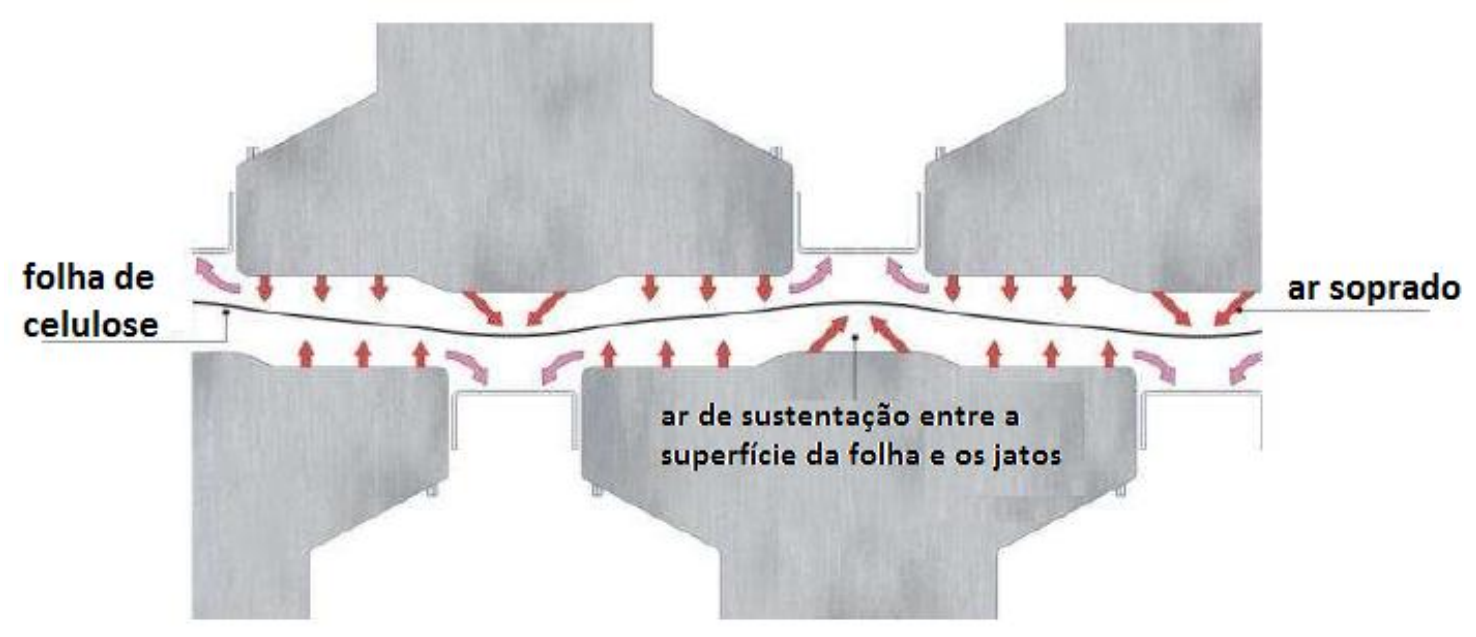

Figura 13 - Vista frontal de um secador horizontal (Bates 2010, editado).

Por outro lado, a ausência desse jato oblíquo também tem um efeito negativo. Se nos secadores horizontais a velocidade de jato, acima e abaixo da folha de celulose, não precisa ser rigorosamente controlada, devido ao efeito estabilizador do jato oblíquo, no secador vertical tal controle é extremamente importante, sendo essa é uma justificativas da realização desse estudo.

Especificamente sobre o tema de escoamento em caixas sopradoras, destacam-se os trabalhos de Milosavljevic e Heikkilä (2004), que demonstraram a correlação entre a velocidade dos jatos de ar de caixas sopradoras com a capacidade de secagem desses jatos. Para tanto os autores procederam a uma verificação entre resultados experimentais e análises via CFD para o estudo das transferências de calor e massa que ocorrem durante 0 processo de secagem por jatos provenientes de caixas sopradoras.

A Figura 14, mostra o procedimento experimental adotado, no qual ar em três condições distintas de temperatura foi impingido contra uma placa circular de diâmetro igual a 20,4 mm, tal placa ficou centralizada e a uma distância de $20 \mathrm{~mm}$ verticalmente do orifício, pelo qual o ar foi impingido. Observam-se também os pontos nos quais as medições foram feita na placa. 
A Figura 15 mostra um gráfico obtido pelos autores da variação do coeficiente de transferência de calor por convecção $(\alpha)$ em função da distância, $r$, entre o centro dos orifícios existentes na caixa sopradora e da temperatura, $\mathrm{Tj}$, do ar quando mantida a velocidade dos jatos de ar constante e igual a $90 \mathrm{~m} / \mathrm{s}$.

Nessa figura pode-se observar que para uma pequena variação na distância r, por exemplo, de oito milímetros, o valor de $\alpha$ varia bruscamente de 750 para $380 \mathrm{~W} /\left(\mathrm{m}^{2} \cdot \mathrm{K}\right)$.
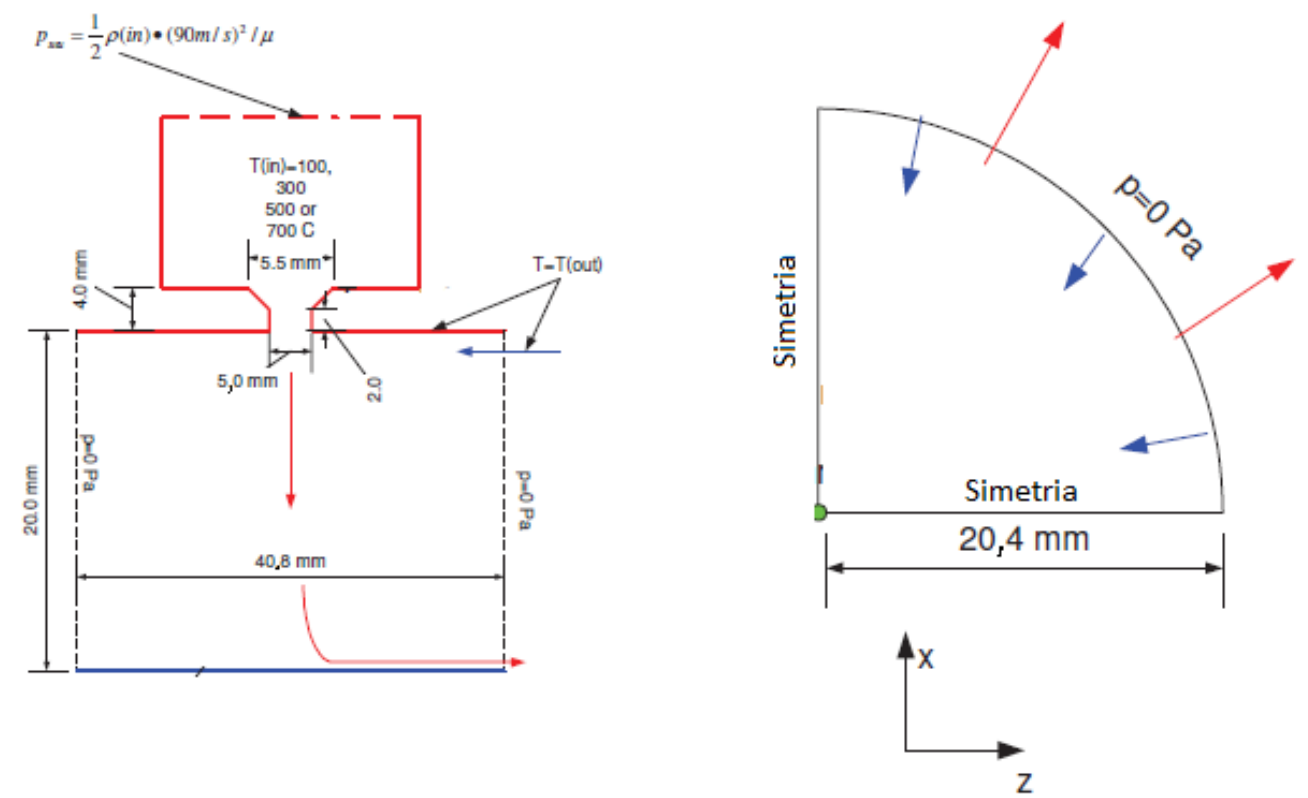

Figura 14 - Esquema experimental adotado (Milosavljevic; Heikkilä, 2004, editado). 


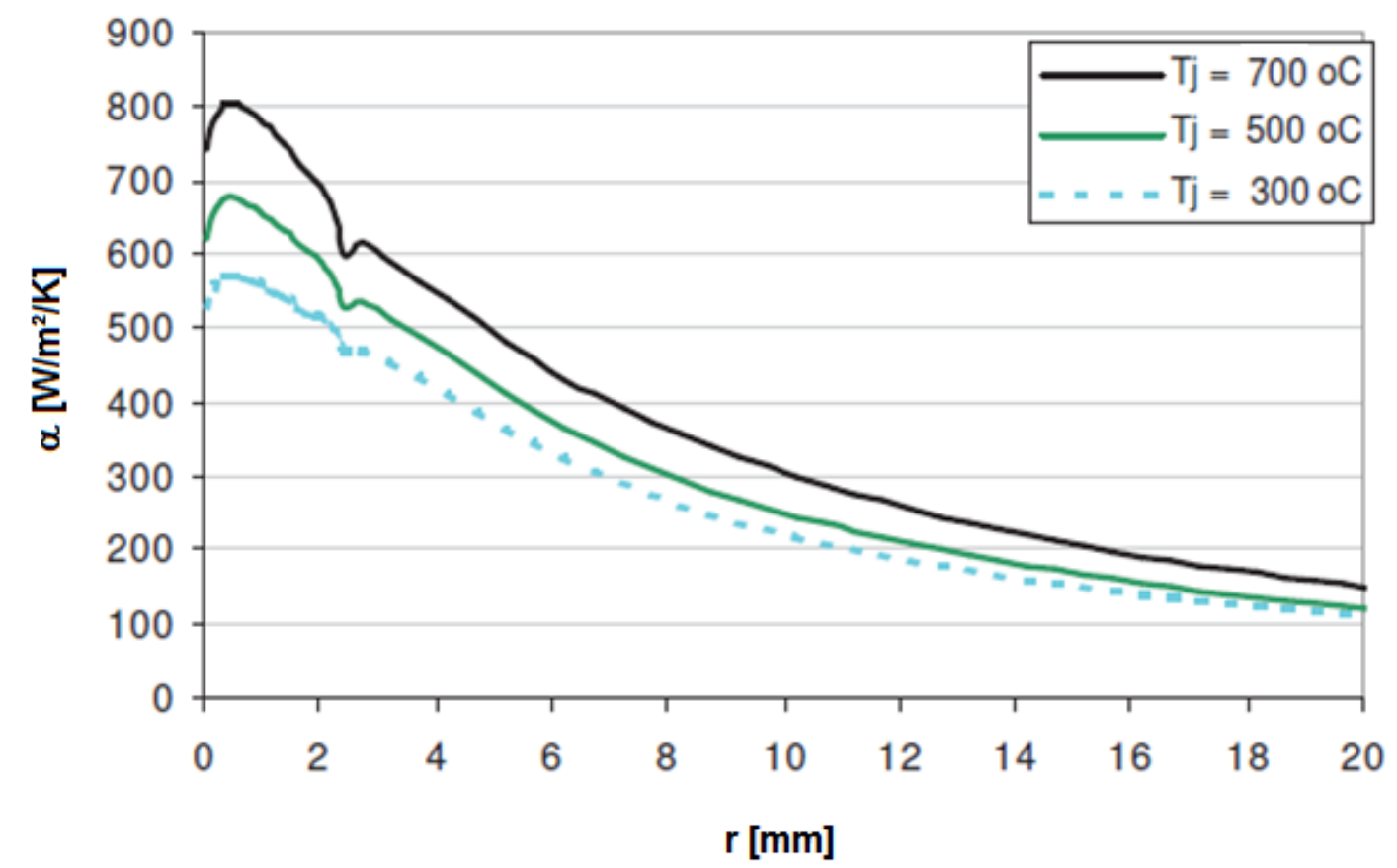

Figura 15 - Variação de $\alpha$ em função da distância radial e da temperatura do ar (Milosavljevic; Heikkilä, 2004)

O controle da uniformidade da velocidade dos jatos de ar tem relação com a necessidade de a secagem ocorrer de maneira uniforme. Alguns dos principais problemas existentes em máquinas desaguadoras de celulose é o perfil não uniforme de umidade no produto final. Tal característica diminui drasticamente seu valor de mercado e obriga o fabricante de celulose a trabalhar em velocidades menores ou a utilizar mais energia no processo de secagem.

Porém algumas das características construtivas do secador horizontal, como principalmente a disposição e localização de seus ventiladores, impedem que o secador como um todo seja projetado de maneira eficiente no que se refere à temperatura e umidade do ar. Isso ocorre principalmente porque no arranjo horizontal da seção de secagem o controle da temperatura e umidade do ar é o mesmo em toda a seção de secagem.

A necessidade da transferência de energia e massa entre $o$ ar e a folha de celulose é variável durante o processo de secagem, pois ao longo do processo de secagem a umidade e temperatura média da folha variam. 
Para o secador horizontal é considerada uma condição média para se determinar os níveis de temperatura e umidade operacionais na seção de secagem, uma vez que esses parâmetros terão que ser constantes.

Ao contrário, no secador vertical, existe a possibilidade de se alterar os níveis de temperatura e umidade em determinadas regiões do secador, adequando-se assim às necessidades do processo localmente.

\subsection{Instabilidades em folhas}

Durante as etapas que envolvem a fabricação de materiais finos, como por exemplo, uma folha de papel, um filme fotográfico ou até mesmo um filme magnético, esses materiais em alguma fase de seu processamento são gerados, ou transformados em, folhas contínuas.

No caso específico da produção de papel ou celulose, como descrito anteriormente, a folha produzida, durante seu processo de secagem percorre distâncias superiores a 10 metros sem ser suportada. Dessa maneira, a folha pode apresentar uma baixa rigidez que pode ser causada por suas características físicas, como sua espessura, que pode ser menor que um milímetro, ou do processo de secagem, como a ausência de sustentação da folha durante seu percurso no secador.

Durante esse processo de secagem existe a interação entre a folha, que se deseja secar, e o ar, impingido contra a mesma. A combinação do ar impingido contra a folha, com a baixa rigidez da mesma, pode ocasionar a vibração de suas arestas livres. Esse tipo de fenômeno, chamado de instabilidade da folha, é correlacionado ao movimento de uma bandeira, exceto por a folha em questão sofrer tração em uma direção devido aos rolos que a guiam durante seu movimento vertical (caso do secador vertical). Porém na direção do ar que é impingido contra a mesma, a folha não possui nenhum tipo de restrição ao seu movimento.

Lamb (1932) propôs que se o ar é impingido ao longo da folha, por propósitos de secagem, o movimento da folha pode se tornar rapidamente 
instável. Já estudos mais recentes, como Chang e Moretti (2002), correlacionaram também o início dessa instabilidade à presença do fluxo de ar transversal ao movimento da folha, na direção em que sua rigidez é mínima devido à impossibilidade de se aplicar tensão na folha nesta direção. A Figura 16 mostra uma representação dessas direções, considerando-se a folha como num secador horizontal.

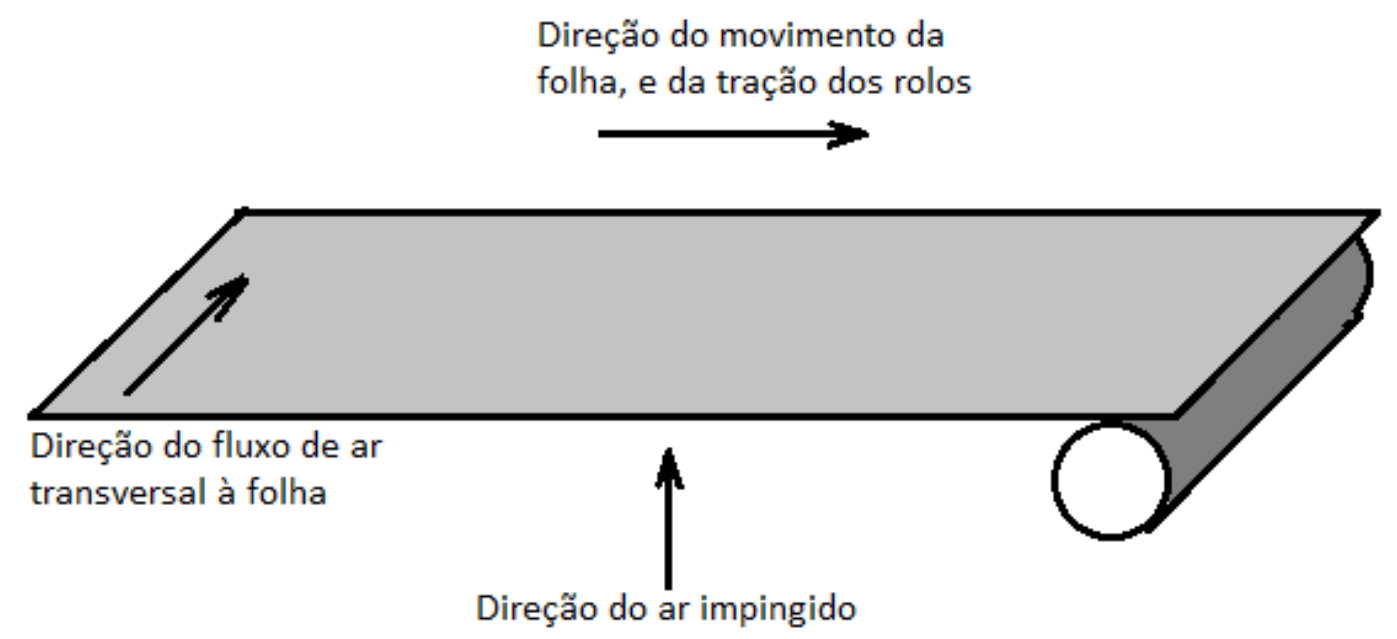

Figura 16 - Representação esquemática das direções referentes ao fluxo de ar e à folha

Chang e Moretti (1999) propuseram equações para o movimento de folhas finas, quando a mesma é afetada por fluxos transversais ou longitudinais, nesses casos o fluxo de ar estudado escoa sempre em paralelo com a folha. No caso do fluxo longitudinal, ele é capaz de promover movimentos fora do plano da folha.

Já para o caso de fluxos de ar transversais foi demonstrado (Chang e Moretti 2002) que a vibração na folha não ocorre devido às turbulências aleatórias e sim por uma bem definida velocidade critica, assim como quando do fenômeno de drapejamento.

No caso do fluxo de ar direto contra a folha, caso da secagem da folha de celulose, pode-se admitir que 0 ar, após o contato contra a folha, segue paralelamente à mesma no sentido transversal. Assim, quanto maior a diferença entre as velocidades dos jatos provenientes da caixa sopradora, mais irregular será a distribuição de pressão na folha, o que irá facilitar o início dos mecanismos de vibração da folha. 
Também, quanto maior a diferença de velocidades entre os jatos, menor será a inércia da folha de papel, e a distância dos jatos à folha será diferente, pois a posição de equilíbrio da folha não será centralizada. Essa redução na área entre a folha e os jatos de ar irá aumentar a velocidade do fluxo de ar transversal, e como verificado por Chang e Moretti (2002), uma pequena variação na velocidade do fluxo de ar transversal pode ocasionar o início de vibrações bastante severas, como mostrado na Figura 17.

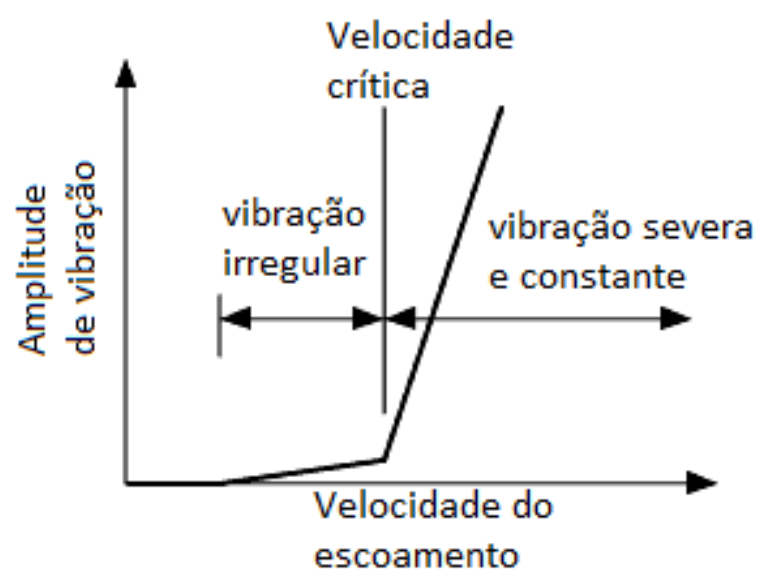

Figura 17 - Comportamento da vibração da folha em função da alteração da velocidade de escoamento (Chang e Moretti 2002, editado).

Watanabe et al. (2002) realizou diversos experimentos que comprovaram a relevância da velocidade do fluxo transversal na vibração das folhas como mostrado na Figura 17, e obtendo a equação 1

$$
U_{w}=4\left(\frac{m}{\rho d}\right)^{-\frac{1}{3}}\left(\frac{T d^{2}}{E I}\right)^{\frac{1}{3}}\left(\frac{E I}{\rho d^{3}}\right)
$$

Onde, $\cup_{\mathrm{w}}$ é a velocidade do fluxo de ar transversal crítica, para a qual a vibração da folha começa. $m$ é a massa por unidade de área da folha, $\rho$ é a massa específica do fluído impingido, T é a tensão aplicada na folha, e El é a rigidez à flexão por unidade de largura da folha.

Assim, esses estudos comprovaram a necessidade de haver uniformidade nos jatos de ar da caixa sopradora, pois essa uniformidade nos jatos de ar é essencial para a manutenção da estabilidade da folha. 


\subsection{Método dos volumes finitos}

Atualmente a modelagem e simulação é uma das principais alternativas para o estudo da dinâmica dos fluidos quando as condições estudadas são complexas, seja devido às condições geométricas, seja pelas condições específicas do escoamento.

Com o enorme desenvolvimento computacional que vem ocorrendo nas duas últimas décadas, o uso de técnicas computacionais para a solução de problemas físicos de elevada complexidade tem se tornado cada vez mais viável. Dessa maneira, estão sendo desenvolvidos diversos algoritmos para a solução de vários tipos de problemas da física e da engenharia.

Portanto o uso de simulação computacional está se disseminando como alternativa para o enfrentamento de desafios das mais diversas origens. Com relação à mecânica dos fluidos, hoje já existem diversas opções de softwares de CFD (computational fluid dynamics).

Desta maneira podem-se dividir as opções de estudos dos problemas de mecânica dos fluidos basicamente em dois grandes grupos:

- Métodos teóricos: analíticos ou numéricos;

- Métodos experimentais.

Enquanto os métodos teóricos têm por objetivo resolver as equações matemáticas que envolvem os fenômenos estudados, os métodos experimentais envolvem recriar, em alguma escala o problema estudado e a partir de dados coletados experimentalmente obter respostas.

Os métodos experimentais, embora possam ser totalmente correspondentes com o problema real estudado, muitas vezes também trazem imprecisões devidas a simplificações de ordem a se tornar possível o experimento.

Tais simplificações podem tanto ser em termos de escala entre 0 problema real e o modelo experimental, como também podem estar nas 
medidas coletadas. Muitas vezes o problema consiste em se analisar regiões onde os experimentos não permitam medições ou até mesmo as interferências das medições nos fenômenos estudados não possam ser desconsideradas.

O método dos volumes finitos (MVF) é um método numérico bastante utilizado para a solução de sistemas de equações diferenciais. Este método foi desenvolvido com o intuito de poder analisar os problemas complexos da mecânica dos fluidos. Neste trabalho utiliza-se o método dos volumes finitos.

O método dos volumes finitos para a solução dos sistemas de equações diferenciais parte dos seguintes passos:

- Discretização da geometria estudada, através da divisão do meio contínuo em volumes elementares;

- Integração das equações nos volumes de controle elementares para construir equações algébricas para as variáveis discretas dependentes, como por exemplo, pressão e temperatura;

- Linearização das equações discretas e solução do sistema de equações lineares resultante para produzir valores atualizados das variáveis independentes.

As equações que governam o escoamento de um fluido são as que representam as leis da conservação. A equação geral do transporte pode ser escrita de duas formas: conservativa e não conservativa. Em sua forma geral, a equação na forma conservativa é dada por:

$$
\frac{\partial}{\partial t}(\rho \phi)+\nabla \cdot(\rho \phi \vec{u})=\nabla \cdot(\Gamma \nabla \phi)+S_{\phi}
$$

Onde:

$\rho=$ massa específica

$\phi=$ propriedade que está sendo transportada

$\vec{u}=$ vetor velocidade do escoamento

$\Gamma=$ coeficiente de difusidade

$\mathrm{S}_{\phi}=$ termo fonte de $\phi$ 
A Equação 2 expressa o balanço de uma dada propriedade $\phi$, o primeiro membro é a soma do termo transiente (taxa de variação temporal de $\phi$ ) com a taxa convectiva de $\phi$ (para o volume elementar analisado) e no segundo membro é a taxa de variação de $\phi$ devido a sua difusão somada a produção de $\phi$ devido a presença de fontes.

Convém ressaltar que para a correta análise de escoamento de fluidos deve-se garantir que os princípios da conservação, em nível discreto, em todos os volumes elementares sejam satisfeitos.

Considerando-se regime permanente, ou seja, a taxa de variação temporal de $\phi$ é nula, a equação de transporte integrado no volume de controle estudado se reduz a:

$$
\int_{V C} \nabla \cdot(\rho \phi \vec{u}) d V=\int_{V C} \nabla \cdot(\Gamma \nabla \phi) d V+\int_{V C} S_{\phi} d V
$$

Aplicando-se o teorema do divergente obtém-se:

$$
\oint(\rho \phi \vec{u}) d \vec{A}=\oint(\Gamma \nabla \phi) d \vec{A}+\int_{V C} S_{\phi} d V
$$

Esta equação deve ser aplicada para cada volume elementar. Essa discretização do domínio em células é convencionalmente chamada de malha computacional. Ou seja, aplica-se a Equação 3 nas diversas faces que compõe as células da malha (D’Agostini Neto, 2011).

Ressalta-se que é necessário usar algum tipo de interpolador para os valores das propriedades calculados nas faces de cada célula. Para tanto existem diversos métodos disponíveis. Um dos métodos mais comuns é o método das diferenças centradas. Uma das principais desvantagens desse método é que a difusão da propriedade $\phi$ não leva em conta a direção do escoamento, quando utilizado na convecção (Buscariolo, 2009).

Para diminuir os efeitos dessa deficiência foi criado um novo esquema, chamado "upwind". Neste esquema o valor final de $\phi$ é tomado na célula a montante, relativa à direção normal do vetor velocidade do escoamento. Para esse esquema, em contrapartida, a principal deficiência ocorre quando a direção do escoamento não está alinhada com as linhas da malha. 
Neste trabalho utilizou-se o software comercial ANSYS CFX, que usa técnicas de MVF (método dos volumes finitos) para a solução de problemas de CFD. Este software, também utiliza a solução de modelos de turbulência, quando necessário. O esquema upwind foi utilizado no Ansys CFX neste trabalho.

\subsection{Conceitos e modelos de turbulência}

Neste trabalho o entendimento dos conceitos relacionados à turbulência, bem como das técnicas para a criação de modelos que sejam capazes de reproduzir tais características foram extremamente importantes, justificando assim a necessidade da abordagem deste tema. Dessa maneira, a correta avaliação das características de turbulência inerentes aos escoamentos estudados é muito importante.

$\mathrm{Na}$ observação de escoamentos, sejam eles no meio industrial ou mesmo na natureza, nota-se que os escoamentos começam a apresentar instabilidades quando um valor crítico para o número de Reynolds é ultrapassado. Se abaixo desse valor crítico o comportamento do escoamento é bem determinado, ao se ultrapassar esse valor o comportamento do escoamento se torna desordenado e de certa maneira até mesmo irreprodutível.

Esses escoamentos são denominados turbulentos, que têm como principal característica realizar eficientemente 0 transporte e a mistura das propriedades físicas apresentando também a vorticidade irregularmente distribuída em todas as direções (turbilhões).

Sabe-se que para altos valores de número de Reynolds (Re), em um escoamento, uma complicada série de eventos passa a exercer grande influência e a alterar radicalmente o comportamento do mesmo, fazendo com que este passe a ser instável. É o chamado regime turbulento. Assim, pode-se considerar que os escoamentos turbulentos são sempre transientes e 
tridimensionais, mesmo quando as características, em nível macro, não tenham variação em relação ao tempo (Tobaldini Neto, 2006).

As escalas dessas estruturas turbilhonares variam desde a ordem das microescalas dissipativas de Kolmogorov (Tennekes e Lumley, 1977) até as grandes estruturas turbilhonares que são características da geometria do escoamento analisado.

Desta maneira pode-se dizer que o estudo de escoamentos turbulentos é de substancial interesse em engenharia, visto que a maioria dos escoamentos é de tal natureza.

O caráter aleatório de um escoamento turbulento permite decompor, por exemplo, a velocidade em uma componente média e em uma componente flutuante $\left(u(t)=U+u^{\prime}(t)\right)$.

Para exibir a influência dessas flutuações turbulentas no escoamento, pode-se, por exemplo, considerar as equações de Navier-Stokes para escoamento incompressível com viscosidade constante. No sistema de coordenadas cartesiano, tem-se:

$$
\begin{gathered}
\nabla \cdot \vec{u}=0 \\
\frac{\partial u}{\partial t}+\nabla(u \cdot \vec{u})=-\frac{1}{\rho} \cdot \frac{\partial p}{\partial x}+v \cdot \nabla^{2} u \\
\frac{\partial v}{\partial t}+\nabla(v \cdot \vec{u})=-\frac{1}{\rho} \cdot \frac{\partial p}{\partial y}+\nu \cdot \nabla^{2} v \\
\frac{\partial w}{\partial t}+\nabla(w \cdot \vec{u})=-\frac{1}{\rho} \cdot \frac{\partial p}{\partial z}+\nu \cdot \nabla^{2} w
\end{gathered}
$$

Quando se adicionam os termos de flutuações nas Equações 6, 7 e 8 chega-se em:

$$
\begin{gathered}
\nabla \cdot \vec{u}=0 \\
\frac{\partial U}{\partial t}+\nabla(U \cdot \vec{U})=-\frac{1}{\rho} \frac{\partial P}{\partial x}+v \cdot \nabla^{2} U+\left[-\frac{\partial \overline{u^{\prime 2}}}{\partial x}-\frac{\partial \overline{u^{\prime} v^{\prime}}}{\partial y}-\frac{\partial \overline{u^{\prime} w^{2}}}{\partial z}\right]
\end{gathered}
$$




$$
\begin{aligned}
& \frac{\partial V}{\partial t}+\nabla(V \cdot \vec{U})=-\frac{1}{\rho} \frac{\partial P}{\partial y}+v \cdot \nabla^{2} V+\left[-\frac{\partial \overline{u^{\prime} v^{\prime}}}{\partial x}-\frac{\partial \overline{v^{\prime 2}}}{\partial y}-\frac{\partial \overline{v^{\prime} w^{\prime}}}{\partial z}\right] \\
& \frac{\partial W}{\partial t}+\nabla(W \cdot \vec{U})=-\frac{1}{\rho} \frac{\partial P}{\partial z}+v \cdot \nabla^{2} V+\left[-\frac{\partial \overline{u^{\prime} w^{\prime}}}{\partial x}-\frac{\partial \overline{v^{\prime} w^{\prime}}}{\partial y}-\frac{\partial \overline{w^{\prime 2}}}{\partial z}\right]
\end{aligned}
$$

As Equações 10, 11 e 12 apresentam termos adicionais devido à adição da flutuação. Estes termos adicionados a cada uma das equações representam seis tensões adicionais, das quais três são tensões normais e três são cisalhantes. Estas tensões são conhecidas com as tensões de Reynolds.

Teoricamente é possível resolver qualquer tipo de escoamento diretamente utilizando-se apenas as equações de Navier-Stokes. Para isso, seria necessário garantir que a malha utilizada fosse suficientemente fina para que todas as escalas de fenômenos físicos fossem englobadas pelas equações discretizadas.

Porém, esse tipo de simulação, chamada de SND (simulação numérica direta) torna-se inviável para valores elevados do número de Reynolds (Libby, 1996).

$\mathrm{Na}$ grande maioria dos casos reais, o número de Reynolds associado aos escoamentos é alto, que torna impossível a solução por meio de modelos SND, assim, para a modelagem matemática desses escoamentos, faz-se necessária a adoção de modelos de turbulência.

Um modelo de turbulência é um procedimento teórico que consiste em determinar um "escoamento médio", de tal forma que escoamentos com características semelhantes às necessárias para a aplicação do mesmo, possam ser resolvidos.

Para a grande maioria das aplicações em engenharia, não é necessário obter soluções exatas para as variações turbulentas, mas sim apenas para as alterações que as mesmas causam no escoamento médio.

Uma das possíveis classificações para os modelos de turbulência é a da razão entre a quantidade da energia turbulenta que é representada pelo modelo em si e a quantidade computada pelos princípios básicos. 
Os modelos com base nas equações médias de Navier-Stokes, que são comumente designados por modelos RANS (Reynolds Averaged NavierStokes), apresentam quase que a totalidade da energia turbulenta modelada.

Outro tipo de modelo são as simulações do tipo LES (Large Eddy Simulation) onde boa parte da energia é computada pelos princípios básicos e apenas uma pequena porcentagem dessa energia é modelada, dessa maneira obtêm-se a vantagem da diminuição do tempo computacional gasto. Nesse tipo de simulação, as equações de Navier-Stokes são filtradas e as escalas de comprimento e parâmetros do filtro utilizado são diretamente dependentes das dimensões dos volumes da malha computacional.

Os modelos clássicos de comprimento de mistura e k-£ são baseados na hipótese de que existe uma analogia entre as ações das tensões viscosas e as tensões de Reynolds no escoamento médio.

Boussinesq propôs que as tensões de Reynolds poderiam estar ligadas às taxas médias de deformação. Assim, essa hipótese indica que a difusão nas menores escalas turbulentas se relaciona de forma linear com as taxas de deformação do escoamento desenvolvido, bem como as tensões viscosas se comportam em fluidos Newtonianos (Ferziger e Peric, 1999).

Isso introduz o conceito de viscosidade turbulenta, que é apresentada na Equação 13:

$$
\frac{\tau_{i j}}{\rho}=-\overline{u_{i}^{\prime} u_{j}^{\prime}}=v_{t}\left(\frac{\partial U_{i}}{\partial x_{j}}+\frac{\partial U_{j}}{\partial x_{i}}\right)-\frac{2}{3} k \delta_{i j}
$$

\subsubsection{Modelo $k-\varepsilon$}

Atualmente uns dos modelos de turbulência mais utilizados é o modelo $\mathrm{k}$ épsilon $(k-\varepsilon)$. Porém esse modelo sempre demonstrou resultados significativamente divergentes para alguns casos específicos. 
Um exemplo de divergência sistemática são os casos onde, por exemplo, ele apresenta altos valores de atrito com as superfícies em escoamentos relativamente simples, sujeitos a grandes gradientes adversos de pressão.

Nesse tipo de modelo o cálculo da viscosidade turbulenta é realizado da seguinte maneira:

$$
\nu_{t}=c_{\mu} \frac{k^{2}}{\varepsilon}
$$

Onde:

$\mathrm{k}=$ energia cinética turbulenta

$\varepsilon=$ taxa de dissipação da viscosidade turbulenta

$\mathrm{C}_{\mu}=$ constante empírica

Os valores locais das variáveis de $\mathrm{k}$ e $\varepsilon$ são calculados através de equações de transporte. Porém, conforme já mencionado, neste modelo ocorre a geração de valores muito altos de coeficiente de atrito em superfícies, quando aplicado para camadas limites com grande efeitos de desaceleração.

Tal efeito é decorrente, principalmente, pelo grande aumento da energia cinética turbulenta e por consequência, da tensão de cisalhamento em regiões próximas à parede. Esse aumento é causado pelo pequeno valor de $\varepsilon$ comparado à taxa de produção de $\mathrm{k}$.

\subsubsection{Modelo $k-\omega$}

Em 1942 Kolmogorov propôs o primeiro modelo de duas equações para turbulência.

Em seu modelo, Kolmogorov considera a energia cinética turbulenta como um dos parâmetros, outro parâmetro considerado é a dissipação por unidade de energia cinética, $\omega$.

O modelo tal como foi proposto tem sido constantemente modificado. Basicamente esse modelo precisava formular uma equação para $\omega$. Para isso, 
primeiramente levou-se em consideração as unidades de $v_{t} / k,[T]$, e de $\varepsilon / k$. $[1 / T]$.

Assim a equação proposta por Kolmogorov foi:

$$
\rho \frac{\partial \omega}{\partial t}+\rho U_{j} \frac{\partial \omega}{\partial x_{j}}=-\beta \rho \omega^{2}+\frac{\partial}{\partial x_{j}}\left(\sigma \mu_{t} \frac{\partial \omega}{\partial x_{j}}\right)
$$

A Equação 14 mostra que não existe um termo de produção de $\omega$, pois ainda segundo Kolmogorov $\omega$ está associada apenas com as pequenas escalas de turbulência, sendo assim não teria nenhuma associação direta com o escoamento médio.

Essa premissa começa a falhar quando, em grandes escalas, a energia turbulenta de fronteira torna-se responsável pela dissipação propriamente dita e pela determinação das escalas de tempo.

Ao longo dos anos novas interpretações para o significado físico de $\omega$ têm sido discutidas. Segundo Wilkox (1994) e Speziale (1990), w deve ser definida como a razão de dissipação por unidade da energia cinética turbulenta.

Esses autores, também passaram a introduzir modificações na equação de $\omega$, como por exemplo, a adoção de um termo de produção para essa grandeza, fato que difere bastaste da proposta original de Kolmogorov.

Assim, foram definidas equações para a viscosidade turbulenta, energia cinética turbulenta e para a taxa de dissipação específica, como mostrado nas equações 16, 17 e 18, respectivamente.

$$
\begin{gathered}
\mu_{t}=\frac{\rho k}{\omega} \\
\rho \frac{\partial k}{\partial t}+\rho U_{j} \frac{\partial k}{\partial x_{j}}=\tau_{i j} \frac{\partial U_{i}}{\partial x_{j}}-\beta^{\star} \rho k \omega+\frac{\partial}{\partial x_{j}}\left[\left(\mu+\sigma^{\star} \mu_{t}\right) \frac{\partial k}{\partial x_{j}}\right] \\
\rho \frac{\partial \omega}{\partial t}+\rho U_{j} \frac{\partial \omega}{\partial x_{j}}=\alpha \frac{\omega}{k} \tau_{i j} \frac{\partial U_{i}}{\partial x_{j}}-\beta \rho k \omega^{2}+\frac{\partial}{\partial x_{j}}\left[\left(\mu+\sigma \mu_{t}\right) \frac{\partial k}{\partial x_{j}}\right]
\end{gathered}
$$

Onde

$\alpha, \beta, \sigma, \beta^{*}, \sigma^{*}=$ são constantes definidas pelo modelo 


$$
\begin{aligned}
& l=\frac{\sqrt{k}}{\omega} \\
& \varepsilon=\beta^{\star} \omega k
\end{aligned}
$$

A maior desvantagem na adoção desse modelo é a grande dependência do nível de turbulência do escoamento médio. Para resolver esse problema, Menter em 1992, propôs um modelo conhecido por BSL (New Baseline $k-\omega$ Turbulence Model). Nele uma função faz com que o modelo se comporte como o modelo $k-\varepsilon$ em regiões afastadas às paredes, e como o $k-\omega$ em regiões próximas às mesmas.

\subsubsection{Modelo k- $\omega S S T$}

Proposto por Florian Menter (1992), esse modelo leva em conta o transporte das tensões cisalhantes e possui melhor comportamento em escoamentos sujeitos a gradientes adversos de pressão.

Além de prever com maior precisão regiões de separação, quando comparado ao modelo $k-\varepsilon$, esse modelo possui uma função que altera o modelo utilizado entre $k-\varepsilon$ e $k-\omega$, em função da distância à parede do ponto considerado (utilizada no modelo BSL). Uma segunda função adicionada limita a viscosidade turbulenta em escoamentos com gradientes adversos de pressão e taxa de dissipação específica.

Com relação ao modelo $k-\omega$, tem-se o aparecimento de um termo na equação de transporte da taxa de dissipação específica.

Os modelos de turbulência discutidos neste trabalho são apenas alguns entre muitos modelos existentes. Tais modelos foram escolhidos para serem utilizados durante as soluções numéricas dos escoamentos estudados.

Optou-se pela escolha desses modelos por terem seu uso bastante difundido e suas limitações já foram bastante discutidas em diversos trabalhos. 


\subsubsection{Parâmetro adimensional $y^{+}$}

As estruturas da turbulência possuem características bastante diferentes das de um escoamento próximo a uma parede sólida, quando comparadas com as características de um escoamento livre.

Analisando-se o número de Reynolds, com relação a uma distância y da parede, pode-se verificar que a partir de certa distância suficientemente distante da parede, $y$, o efeito das forças inerciais é predominante.

Para valores de y, nas regiões mais próximas à parede, o número de Reynolds é menor, o que implica que as forças viscosas prevalecem.

Foi, contudo, demonstrado por Schlichting (1979), que a velocidade média da região da parede, depende não só de y, como também da massa específica, viscosidade e da tensão de cisalhamento da parede, conforme mostrado na equação 19.

$$
u^{+}=\frac{U}{u_{\tau}}=f\left(\frac{\rho u_{\tau}}{\mu}\right)=f\left(y^{+}\right)
$$

\subsection{Modelagem semi-empírica}

Enquanto um estudo empírico se relaciona com a observação apenas experimental dos fenômenos que se deseja estudar, utiliza-se o termo semi-empírico para o estudo que se apoia tanto no uso de equacionamento teórico como também na adoção de parâmetros medidos experimentalmente.

Uma razão a favor do uso de modelagem semi-empírica é a pequena necessidade de tempo computacional para implementação e processamento. Tempo muito menor que aquele utilizado na simulação numérica, estimado em mais de 80 horas, apenas para o processamento computacional de cada modelo ou novas condições analisadas.

A modelagem semi-empírica, utilizada adota equacionamento teórico com aplicação das equações fundamentais da mecânica dos fluidos, equações da 
energia e continuidade, aplicadas ao estudo do escoamento de fluido em um duto principal e que deste duto segue sendo distribuído para dutos com ramais posicionados em direções ortogonais ao principal. O maior desafio na solução deste equacionamento é definir valores para as perdas de pressão adequadas às geometrias específicas e às razões de valores de vazão e velocidades que ocorrem entre as seções do duto principal e dos ramais nas saídas laterais. No presente caso, das caixas sopradoras, os ramais de saída lateral são orifícios de seção circular de pequena área quando comparada à área da seção do duto principal. Outro parâmetro que deve ser considerado é a variação de área nas seções transversais de escoamento no duto principal, característica geométrica importante adotada nas propostas de geometria que buscava o balanceamento das vazões nas saídas laterais.

Foi feita ampla pesquisa na literatura para viabilizar coeficientes de perda em dutos com seção transversal variável.

O melhor conjunto de valores experimentais e possível de ser utilizado foi encontrado em Idelchik (2008). Este autor estuda alternativas para obter-se a distribuição de vazões em ramais laterais de modo mais uniforme possível, a partir de um duto principal com múltiplas saídas. A solução considerada propõe alteração da seção transversal utilizada no duto principal.

A Figura 18 mostra alguns exemplos de dutos com seção transversal variável com saídas por ramais laterais. Aquelas que podem ser correlacionadas ao caso deste estudo são chamadas pelo autor Idelchik (2008) de junções divergentes. A área da seção transversal do duto principal na posição à montante da saída lateral é maior e que aquela que está posicionada à jusante da saída lateral.

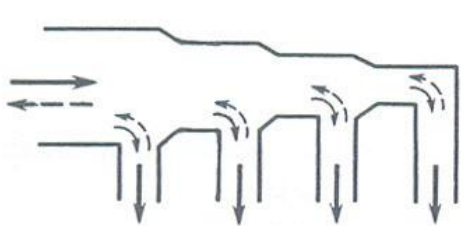

(a)

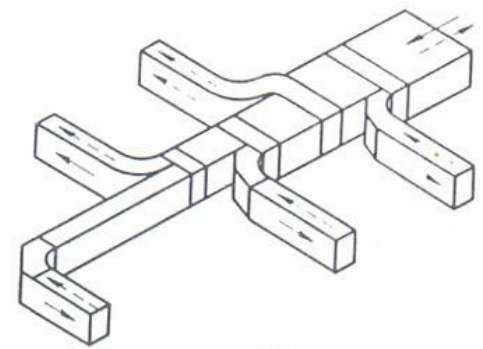

(b)

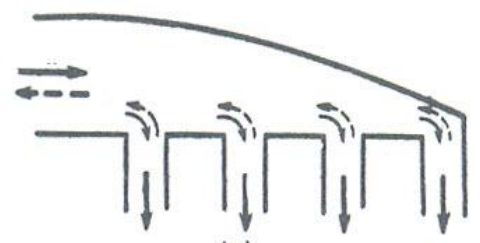

(c)

Figura 18 - Dutos de seção transversal variável com múltiplos canais (Idelchik, 2008). 


\subsection{Câmara de secagem}

Para se entender completamente as caixas sopradoras existentes em máquinas desaguadoras de celulose, existe a necessidade de compreender melhor a divisão do fluxo de ar dentro da câmara de secagem. Pois a uniformidade da alimentação das caixas sopradoras depende da geometria da câmara de secagem.

Câmara de secagem é a região presente nos secadores de celulose que une um ventilador radial às caixas sopradoras. Cada câmara de secagem é isolada uma das outras, através da presença de chapas metálicas que impedem o movimento de ar entre diferentes câmaras, de maneira que o ar insuflado pelo ventilador presente em uma câmara de secagem só pode alimentar as caixas sopradoras presentes na mesma câmara. $O$ conjunto de centenas de câmaras de secagem forma o que se denomina seção de secagem de uma máquina desaguadora de celulose.

Os resultados e modelos a seguir foram propostos por Penteado (2012), quando do estudo de uma câmara de secagem específica. A câmara proposta no modelo estudado por Penteado (2012) pode ser considerada a mesma que seria utilizada para a alimentação das caixas sopradoras propostas neste estudo.

Para as condições específicas estudadas, cada câmara de secagem apresenta sua alimentação feita por um ventilador radial e cada câmara alimenta 80 caixas sopradoras dispostas da seguinte forma: cinco linhas de caixas (direção do movimento vertical da folha de celulose) e 16 colunas de caixa (transversalmente à máquina desaguadora de celulose). 


\subsubsection{Geometria da Câmara de Secagem}

A câmara de secagem era constituída de 80 caixas sopradoras cujo modelo foi descrito acima.

Cada câmara de secagem pode ser alimentada por um ou mais ventiladores. A Figura 19 representa uma vista superior de uma câmara de secagem, alimentada por um único ventilador e com 6 caixas sopradoras. Assim, a quantidade de ar que cada caixa sopradora recebe é totalmente dependente da geometria da câmara de secagem.

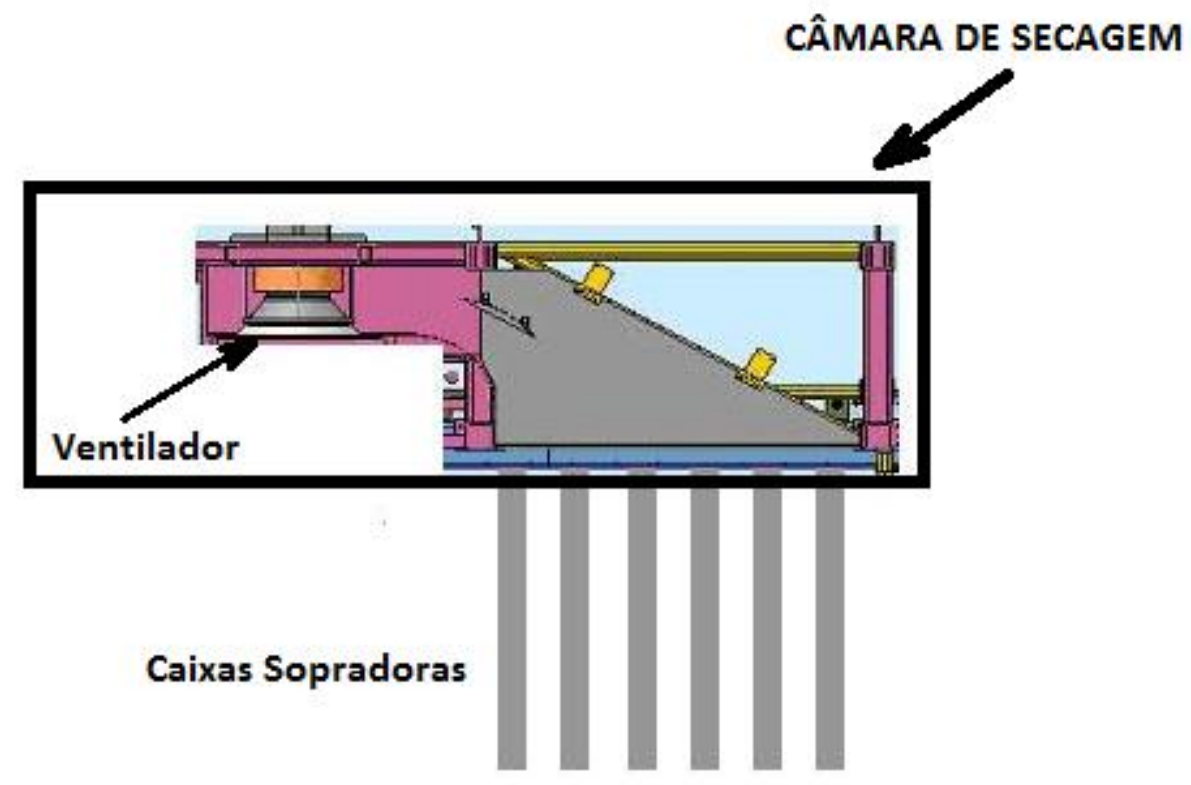

Figura 19 - Vista superior de um leiaute de uma câmara de secagem (Penteado, 2012).

Observa-se na Figura 20 o percurso do ar no interior da câmara de secagem e a conexão com as caixas sopradoras. 


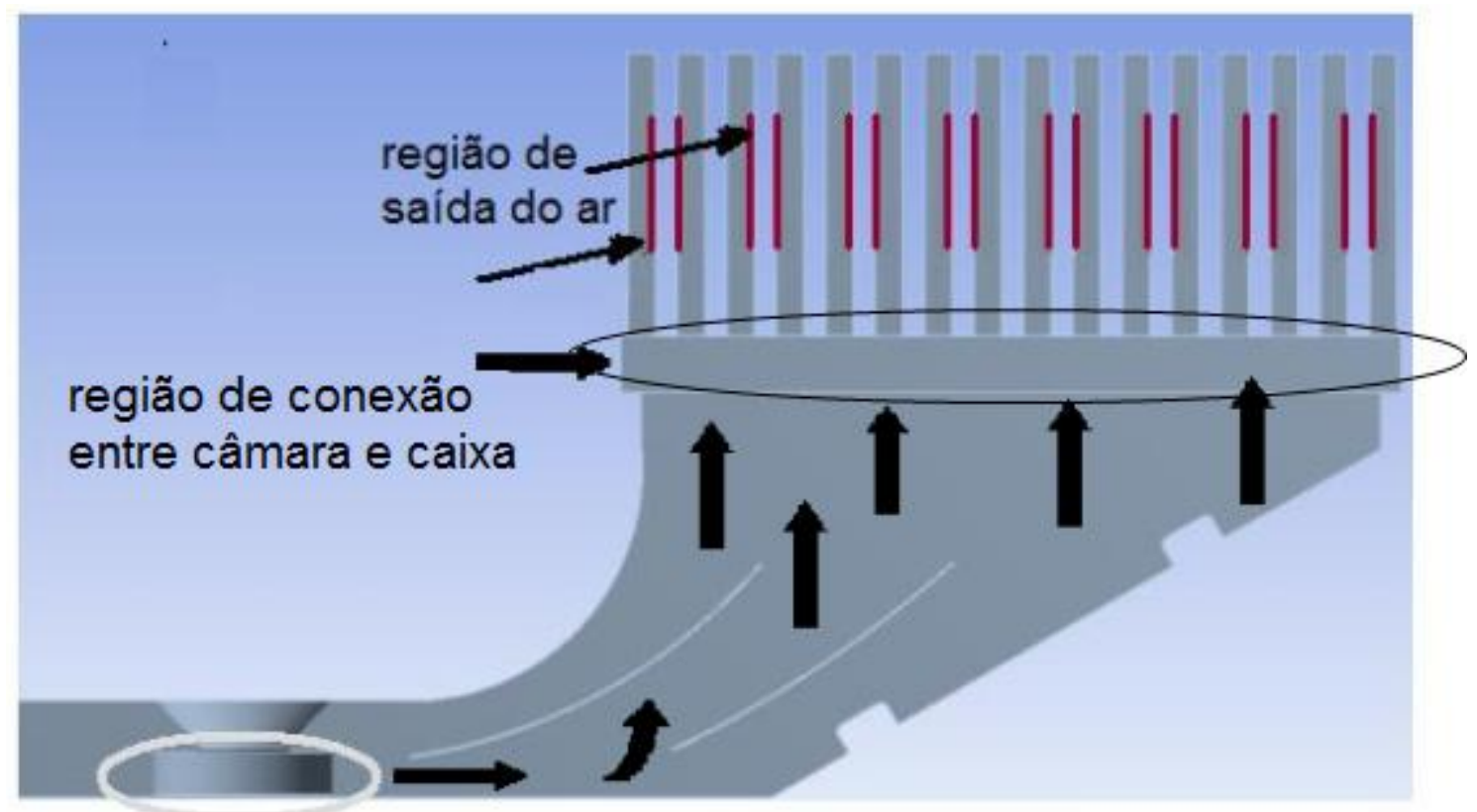

\section{Entrada de ar ventilador radial}

Figura 20 - Direção do fluxo de ar e geometria câmara de secagem para 16 colunas de caixas sopradoras, faces em vermelho são as regiões dos orifícios. (Penteado, 2012).

\subsubsection{Simulação numérica}

Todas as simulações que são realizadas para as caixas sopradoras neste trabalho e também os ensaios realizados, levaram em consideração que a distribuição de ar na entrada das caixas é suficientemente uniforme, de maneira que o não se torna necessário o estudo da região da câmara de secagem. Para analisar essa hipótese foi utilizado um estudo realizado por Penteado (2012). Neste estudo foi modelada a região da câmara de secagem, a Figura 21 mostra uma imagem da malha numérica utilizada. 


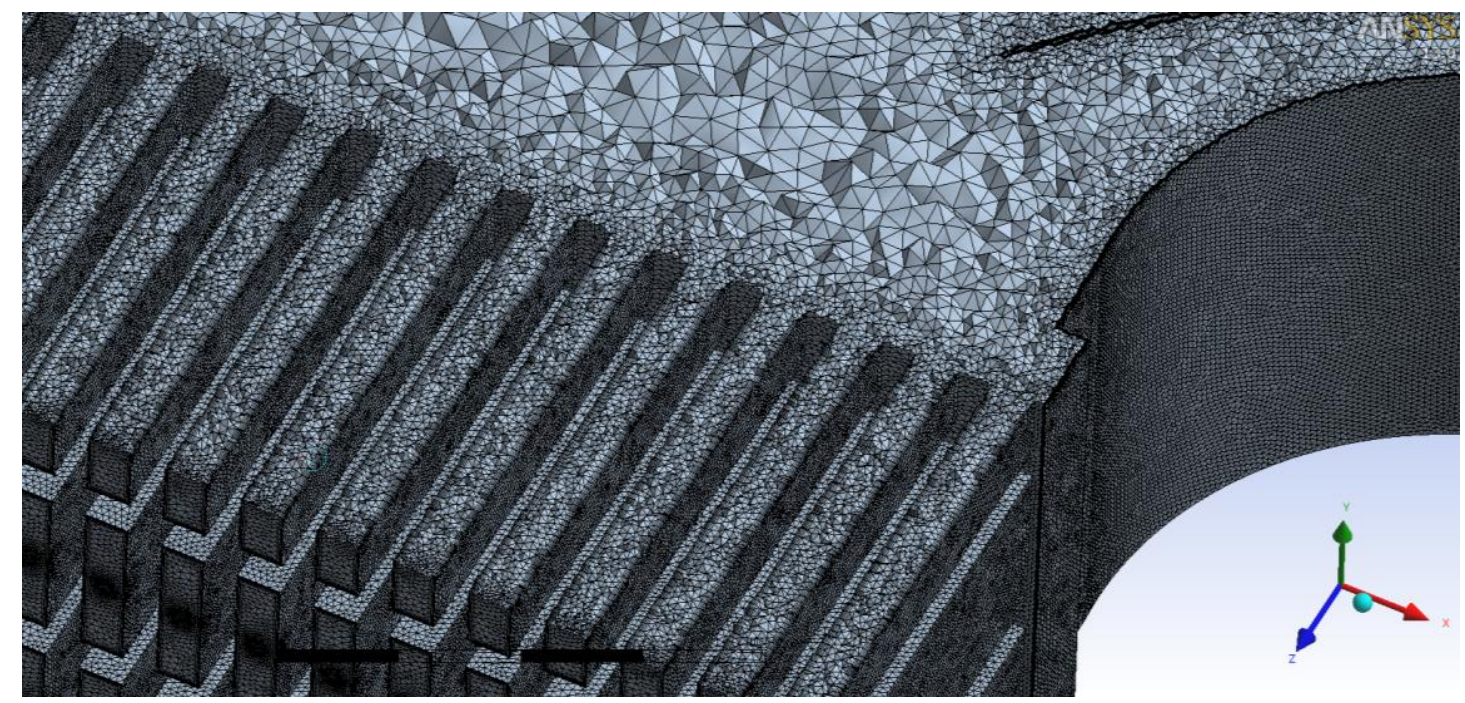

Figura 21 - Modelo numérico com malha para a da câmara de secagem (Penteado, 2012).

A distribuição da vazão de ar por caixa está representada na Figura 22. As caixas sopradoras foram numeradas da seguinte forma: primeiramente por linhas da mais próxima do ventilador até à mais distante, depois por colunas de cima para baixo. Como o papel é ventilado simultaneamente pela esquerda e pela direita os resultados foram separados considerando o lado pelo qual a caixa sopradora ventila a folha. 


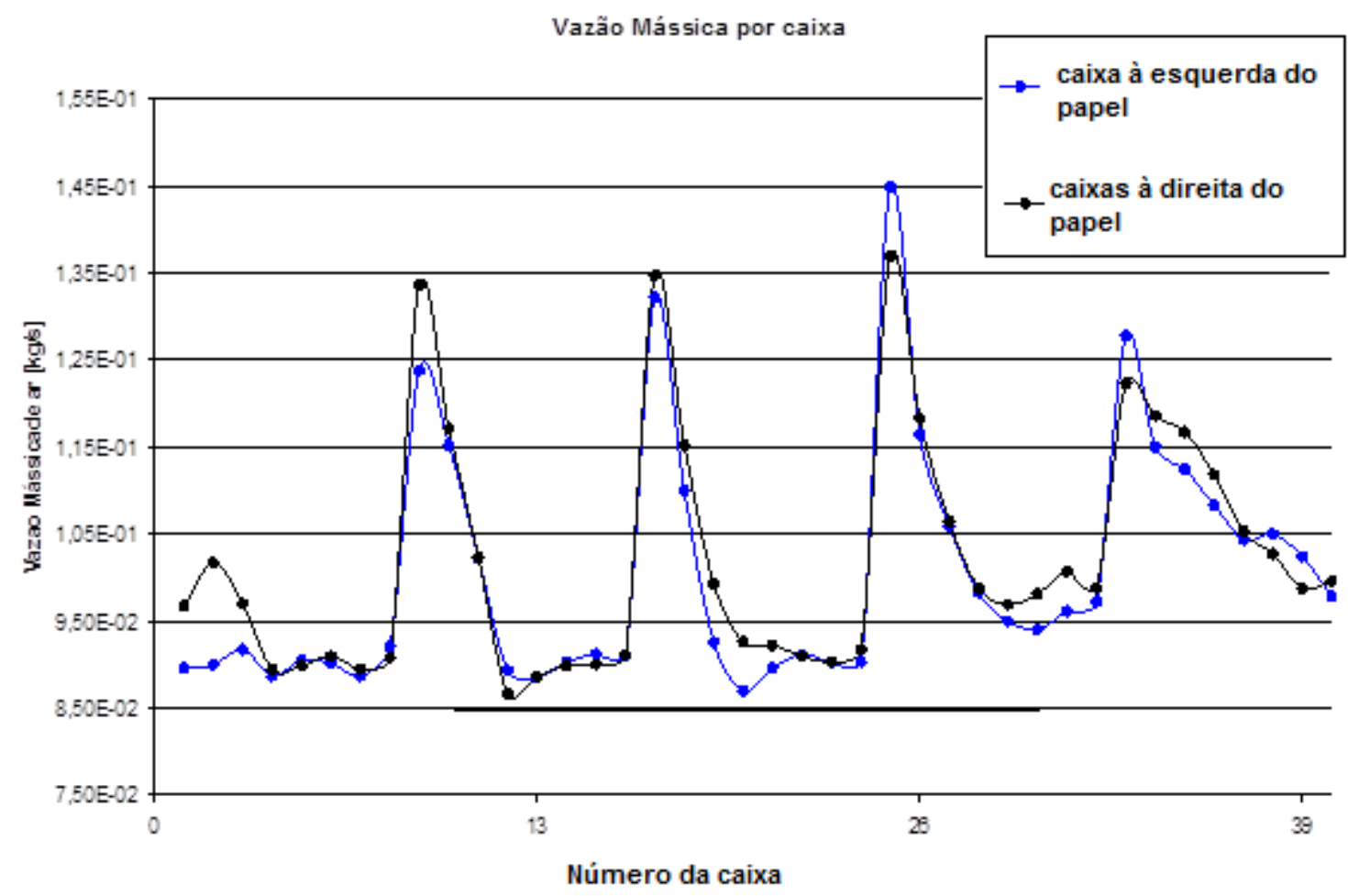

Figura 22 - Vazão Mássica de ar por caixa sopradora (Penteado, 2012).

A Figura 23 mostra um esquema da vista frontal da câmara de secagem estudada, com a numeração de algumas das caixas sopradoras, usando-se a convenção de numeração definida. As caixas da esquerda com numeração em azul, as da direita com numeração em preto, o percurso que a folha de celulose faz, em vermelho, e a posição do ventilador em cinza. 


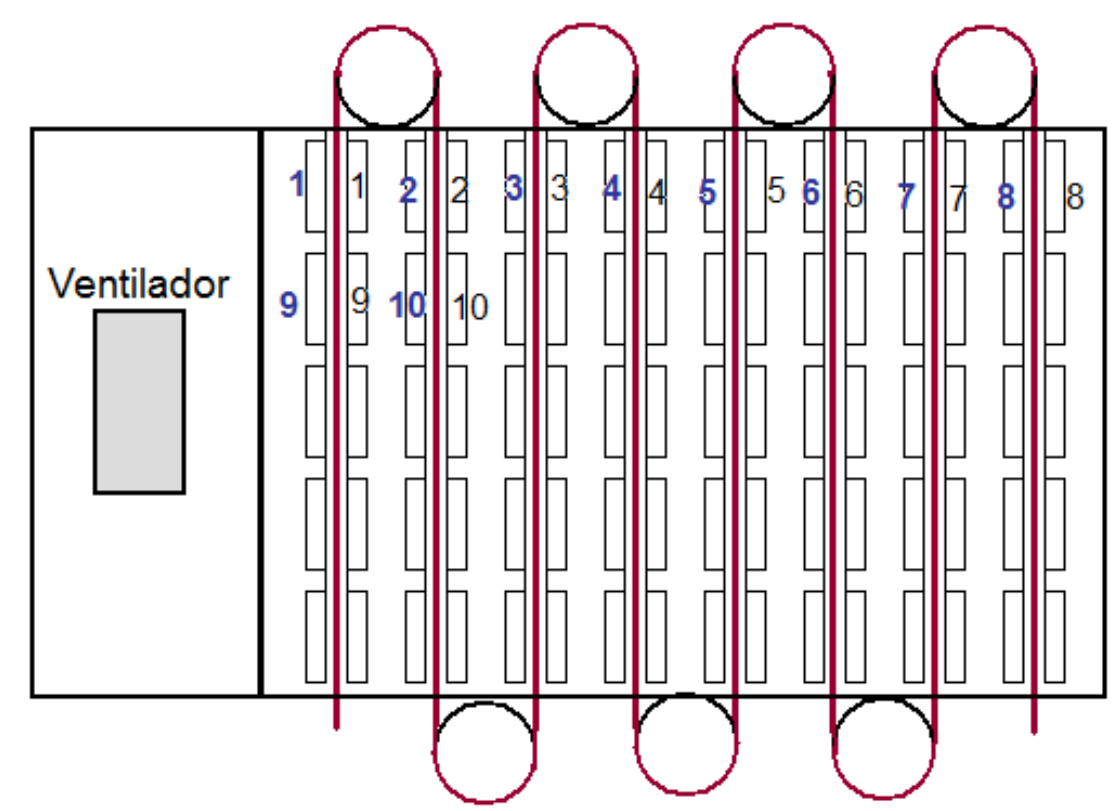

Figura 23 - Exemplo da numeração utilizada para as caixas sopradoras

A vazão mássica média de ar encontrada para as caixas sopradoras foi de $0,101 \mathrm{~kg} / \mathrm{s}$ com um desvio padrão de $\pm 6 \%$. Porém a amplitude da variação da vazão mássica é da ordem de $30 \%$, quando se compara as maiores vazões obtidas e a média encontrada. Essa diferença significativa indica um desbalanceamento das vazões de ar entre as várias caixas sopradoras.

Considerando-se essa amplitude de variação para a vazão mássica, expressa Figura 22, é adotado neste estudo que as simulações numéricas sejam realizadas com valores de vazão nominal e também com valores $30 \%$ superior a nominal.

\subsection{Ensaios em caixas sopradoras}

Foram realizados ensaios de bancada para a análise e determinação de parâmetros, geométricos e térmicos para as caixas sopradoras pela Voith Paper (2011) entre janeiro e maio de 2011.

Tais testes ocorreram utilizando-se de um protótipo de caixa sopradora, e que tinha como objetivo principal determinar como o funcionamento da caixa 
sopradora poderia ser influenciar a secagem da celulose através da alteração da quantidade e disposição dos orifícios que compõe a caixa sopradora, bem como a influência da distância entre os jatos de ar provenientes da caixa e a folha de celulose que se deseja secar.

Para esse ensaio, foram construídas diversas opções de disposição dos orifícios e simulou-se a eficiência na secagem através da analise do resfriamento de uma chapa de cobre a partir dos jatos de ar (a temperatura ambiente) provenientes da caixa sopradora.

Uma vez que a disposição e quantidade de orifícios foram determinadas, foi realizado um ensaio com ar na temperatura de trabalho numa máquina desaguadora real, de maneira a se determinar qual para o valor de pressão ensaiado com seria a velocidade obtida nos jatos de ar.

Assim pode-se observar qual era o efeito de contração nos jatos da caixa sopradora e também a influência da variação da velocidade dos jatos no processo de secagem. De acordo com os resultados experimentais obtidos, uma pequena variação de velocidade do jato de ar, maior que 3\%, já seria suficiente para que se houvesse perda significativa da eficiência energética (Voith Paper, 2011).

Porém, também foram medidos parâmetros de extremo interesse para este trabalho. Considerando-se os parâmetros de alimentação de ar idênticos aos da simulação numérica utilizados neste trabalho obteve-se dos ensaios experimentais o valor de $30,0 \mathrm{~m} / \mathrm{s}$ para a velocidade média dos jatos de ar. Foi medida a diferença da pressão de $350 \mathrm{~Pa}$ entre a entrada e a saída da caixa sopradora.

Menciona-se, que os ensaios não tinham o propósito de gerar dados para este estudo, ou seja, o foco das análises desses ensaios não foram sobre os desafios aerodinâmicos existentes na caixa sopradora. Procurava-se descobrir, por meio destes ensaios, parâmetros geométricos, tais como disposição dos orifícios da caixa sopradora ou diâmetro destes que melhorassem a eficiência energética do processo de secagem da celulose. Mas os dados obtidos como velocidade média dos jatos de ar e a pressão de trabalho que será necessária 
para tal velocidade foram muito úteis para a comparação entre a simulação numérica e experimental.

Convém ressaltar que a maneira de proporcionar a entrada de ar nesses protótipos de caixas sopradoras foi bastante similar ao método empregado numericamente. O protótipo foi alimentado com um fluxo constante e uniforme de ar. Tal fluxo já se encontrava plenamente desenvolvido ao atingir a entrada do protótipo.

A Figura 24 mostra uma imagem do protótipo sendo ensaiado.

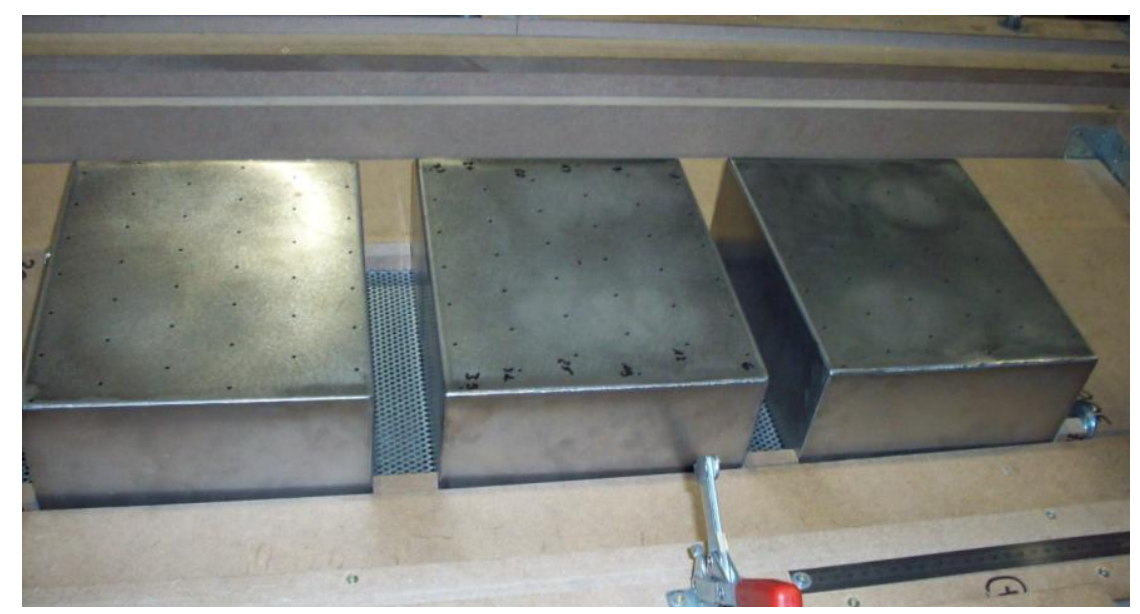

Figura 24 - Exemplo de modelos ensaiados (Voith Paper, 2011). 


\section{METODOLOGIA E DEFINIÇÕES DOS MODELOS}

\subsection{Descrição da seção de secagem}

Como descrito, os dutos com múltiplas saídas são responsáveis diretamente pela de secagem da folha de celulose. Sua geometria deve ser de simples fabricação para garantir baixo custo e agilidade em sua produção seriada. Sua alimentação é realizada através de ventiladores instalados próximos a essas caixas, por razões construtivas são vários os ventiladores necessários para alimentar todas as caixas sopradoras existentes numa seção de secagem.

A dependência da uniformidade na velocidade dos jatos de ar foi comprovada nos resultados obtidos experimentalmente pela Voith Paper (2010) e também nos resultados numéricos obtidos por Milosavljevic e Heikkilä (2004), de maneira que essa uniformidade é necessária para garantir maior eficiência no processo de secagem. Também foi determinada que para as condições específicas testadas, a velocidade média de jato de ar de $32,7 \mathrm{~m} / \mathrm{s}$ garante a maior eficiência para o processo de secagem.

Também se observou pelo trabalho de Milosavljevic e Heikkilä (2004) que uma pequena variação dessa velocidade média dos jatos causaria impactos significativos na transferência de energia como um todo. Assim, para garantir o melhor aproveitamento da energia consumida durante o processo de secagem, deve-se garantir que a velocidade dos jatos não varie além de $3 \%$, o que nesse estudo representaria uma faixa de velocidades entre $31,7 \mathrm{~m} / \mathrm{s}$ e $33,7 \mathrm{~m} / \mathrm{s}$.

O processo de fabricação das caixas sopradoras consiste primeiramente na divisão da mesma em três partes. A primeira parte inclui a face furada do paralelepípedo e as duas laterais adjacentes a essa face furada. A segunda parte corresponde à face oposta à face furada (chamada de face traseira da caixa sopradora) e essa face é encaixada à primeira parte. Posteriormente, na terceira parte coloca-se uma chapa de fechamento na face oposta à face de 
alimentação da caixa sopradora. Como já mencionado, uma das limitações deste trabalho se refere às alterações no projeto da caixa sopradora. Procurarse-á evitar soluções que envolvam dificultar de maneira significativa o método construtivo das caixas sopradoras.

\subsection{Geometria das caixas sopradoras modeladas}

A seguir serão explicitados os modelos de caixas sopradoras adotados durante as simulações numéricas realizadas.

5.2.1. Caixa sopradora de seção transversal uniforme

O modelo inicial de caixa sopradora estudado neste trabalho constitui-se de um paralelepípedo de 5 metros de comprimento (no sentido transversal à máquina desaguadora de celulose), por 300 milímetros de altura e 85 milímetros de largura, conforme pode ser visto na Figura 25 e Figura 26.

Estas dimensões correspondem às dimensões internas da caixa sopradora, ou seja, não levam em consideração as espessuras de chapas de aço necessárias para a construção da mesma. Esse modelo será denominado de caixa sopradora de seção transversal uniforme.

As distâncias consideradas entre os orifícios foram de $80 \mathrm{~mm}$ para orifícios numa mesma linha e de $60 \mathrm{~mm}$ entre linhas de orifícios, num total de 55 colunas de orifícios distribuídas em 5 linhas.

O diâmetro de todos os orifícios é de $4 \mathrm{~mm}$. Ressaltando-se que a distância da primeira e última linha de orifícios para as laterais da caixa sopradora foram de $30 \mathrm{~mm}$ e a distância entre o começo da caixa sopradora e a primeira coluna de orifícios foi de $340 \mathrm{~mm}$. Esses orifícios serão as únicas saídas possíveis para o ar no interior da caixa. 


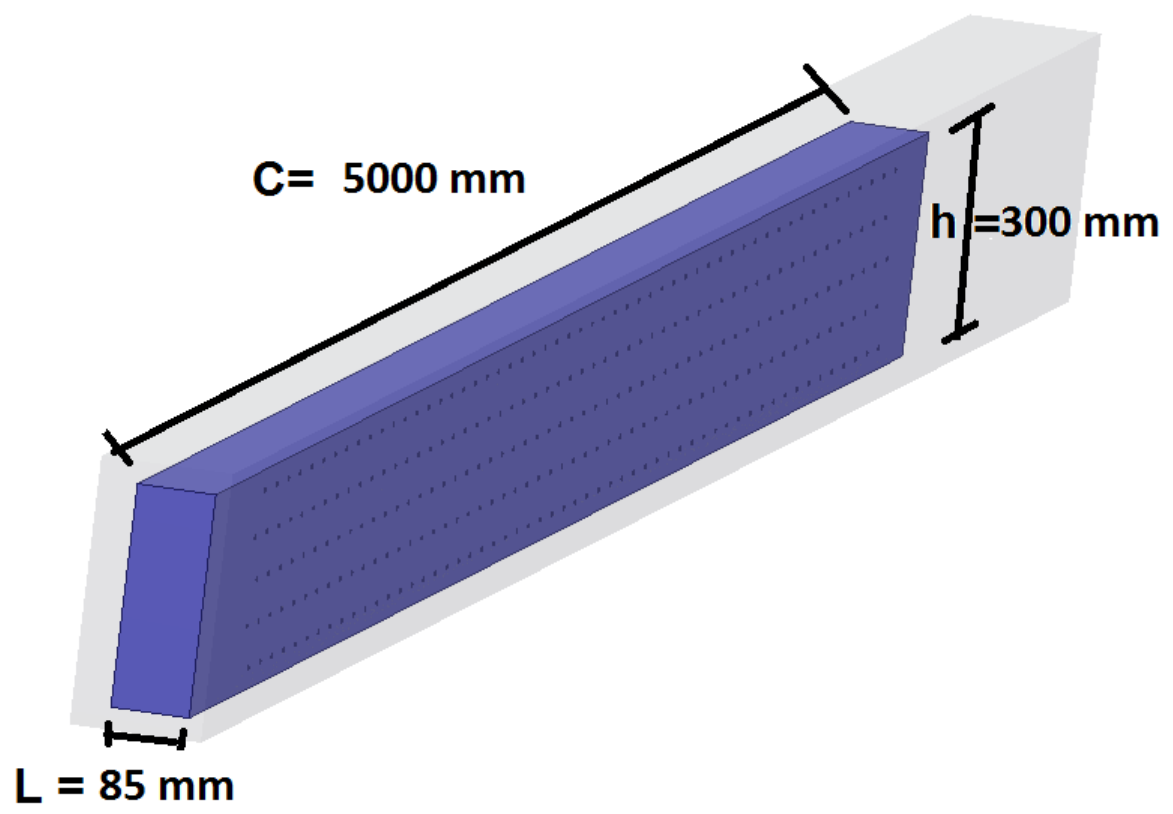

Figura 26 - Geometria do modelo considerado.

A Figura 26 mostra o modelo geométrico utilizado. Pode-se observar que tanto no início da caixa sopradora, quanto em seu final não existe furação. Isso acontece devido à folha de celulose ser menor que a largura total da caixa sopradora, o que torna desnecessário insuflar ar em toda sua largura.

O modelo adotado levou em consideração, além do ar no interior da caixa sopradora, uma região do ar externo à caixa. Esse procedimento visa garantir que mesmo sendo modelada apenas uma caixa sopradora, os efeitos da presença das demais caixas sejam considerados. Relembrando que um conjunto de caixas sopradoras numa mesma seção de insuflação de ar quente é denominado de câmara de secagem. Assim os limites do ar externo levam 
em consideração as particularidades do posicionamento de uma caixa em relação ao todo numa Câmara de Secagem.

Considera-se que o comportamento em todas as caixas sopradoras é o mesmo, ou seja, a distribuição do ar no interior das câmaras não apresente grandes diferenças entre elas.

\subsubsection{Caixa sopradora de seção transversal variável}

Além da caixa sopradora de seção transversal uniforme apresentada anteriormente, é considerada também a possibilidade de se variar uniformemente a seção transversal da caixa sopradora através da mudança de sua largura e mantendo-se inalterados seu comprimento e altura. A Figura 27 mostra como seria possível um novo esquema para as caixas em questão, através da alteração do ângulo $\beta$.

Dessa maneira, os valores de $\mathrm{C}$ e $\mathrm{h}$ para a caixa sopradora de seção transversal variável são iguais a $5000 \mathrm{~mm}$ e $300 \mathrm{~mm}$ respectivamente, a disposição dos orifícios será a mesma do modelo com seção transversal uniforme, e a largura da caixa se iniciará em $85 \mathrm{~mm}$ e será uniformemente reduzida até $25,5 \mathrm{~mm}$. 


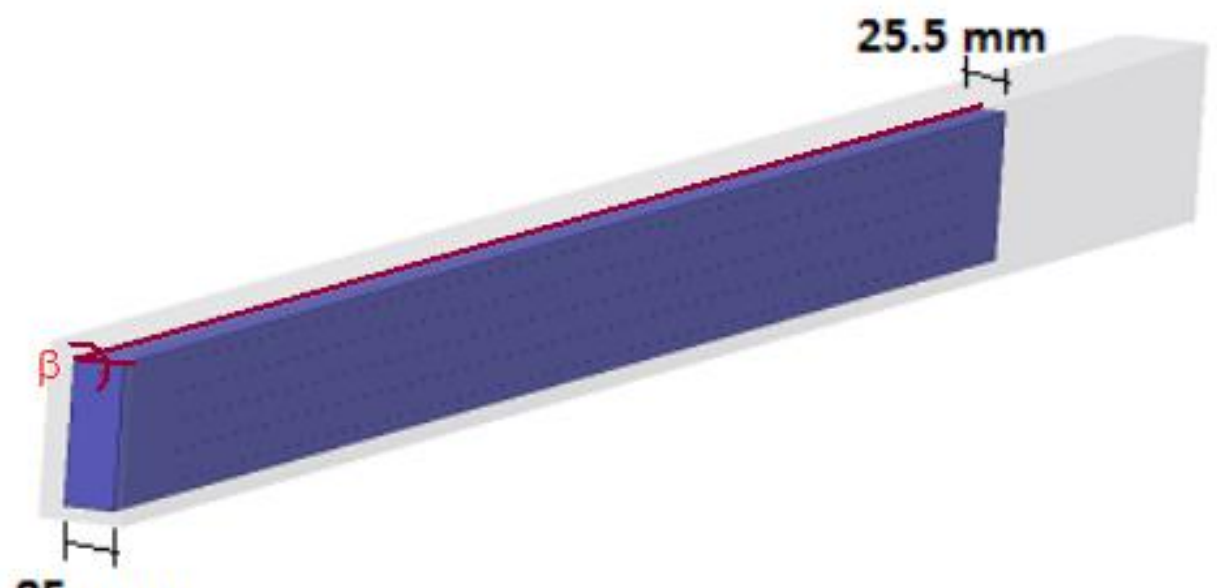

$85 \mathrm{~mm}$

Figura 27 - Modelo geométrico utilizado para caixa sopradora seção variável.

Para a elaboração desse novo modelo foram consideradas as seguintes condições simultâneas:

- Seção transversal no início da caixa permaneceu inalterada, tal condição foi imposta para que a montagem da caixa sopradora na câmara de secagem não fosse alterada.

- Seção transversal final correspondente a $30 \%$ da área de seção transversal no início da caixa sopradora;

- A variação da seção transversal se dará apenas pela inclinação da face traseira da caixa, alteração do ângulo $\beta$ de $90^{\circ}$ para $89,32^{\circ}$.

Os demais limites do modelo analisado não são alterados, ou seja, a parte do domínio que se refere ao ar externo à caixa sopradora não sofre alterações nesta alternativa.

\subsubsection{Caixa sopradora de teste}

Também é proposto nesse trabalho um modelo de caixa sopradora semelhante ao modelo utilizado em ensaios experimentais (Voith Paper, 2010). Neste modelo foi considerada apenas uma fileira de orifícios na caixa 
sopradora. As dimensões do modelo de caixa sopradora de teste são mostradas na Figura 28, que representa uma vista da face perfurada da caixa sopradora.

A largura da caixa sopradora foi mantida constante nesse modelo é igual a $85 \mathrm{~mm}$. A distância entre orifícios foi de $80 \mathrm{~mm}$ e estes se encontravam centralizados na caixa sopradora, considerados em uma única linha e totalizando 20 orifícios, o diâmetro desses orifícios também foi de $4 \mathrm{~mm}$.

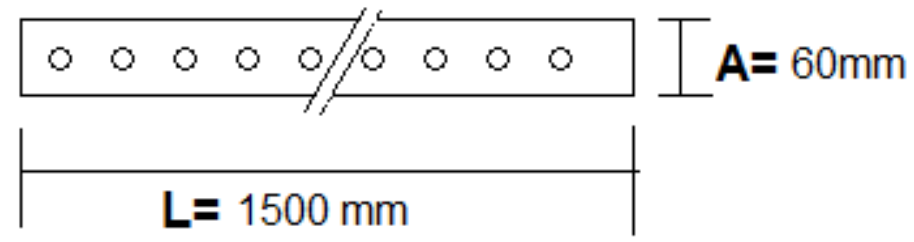

Figura 28 - Vista da face perfurada para caixa sopradora de teste.

\subsection{Aplicação dos métodos de simulação numérica}

Devido às características do escoamento analisado no interior e externamente à caixa sopradora, e principalmente devido às grandes diferenças entre as dimensões da caixa sopradora, deve haver uma atenção especial na definição da malha numérica utilizada.

Para maior facilidade na geração de malhas, adotou-se na aplicação do software comercial ANSYS CFX 13.0, a divisão do modelo da caixa sopradora nas seguintes regiões:

- Região interna à caixa sopradora, que contempla todo o ar interno à caixa, desde sua entrada, na ligação entre a caixa sopradora e a câmara de secagem, até a região onde fica a chapa perfurada da caixa sopradora, porém sem incluir o ar que preencherá os orifícios desta chapa;

- Região dos orifícios, correspondente ao ar que fica na face perfurada da caixa sopradora, ou seja, é o ar que está contido dentro dos orifícios presentes; 
- Região externa à caixa sopradora, região após a saída do ar interior da caixa até as fronteiras do modelo, que serão a metade da distância entre caixas sopradoras adjacentes ou a distância entre a caixa sopradora e a folha de celulose.

A Figura 29 mostra, em um corte feito em toda a largura da caixa sopradora e que passa pelo centro de uma das linhas de orifícios, um exemplo de malha para a caixa sopradora na região interna à caixa sopradora.

Novamente, devido às grandes diferenças entre as dimensões da caixa sopradora, torna-se impossível obter uma imagem que detalhe simultaneamente a malha geral na caixa sopradora e o refinamento feito na malha na região dos orifícios.

Pode-se perceber, contudo, que são criadas camadas prismáticas em torno das paredes para computar os efeitos das paredes no escoamento médio estudado.

Em contrapartida, pode-se notar que a região central da caixa sopradora é modelada com tetraedros de maior volume. Tal crescimento é controlado para que não ocorresse de maneira muito rápida, sabe-se que quando duas células vizinhas têm volumes muito diferentes isso aumenta o erro numérico, dificultando a convergência dos resultados.

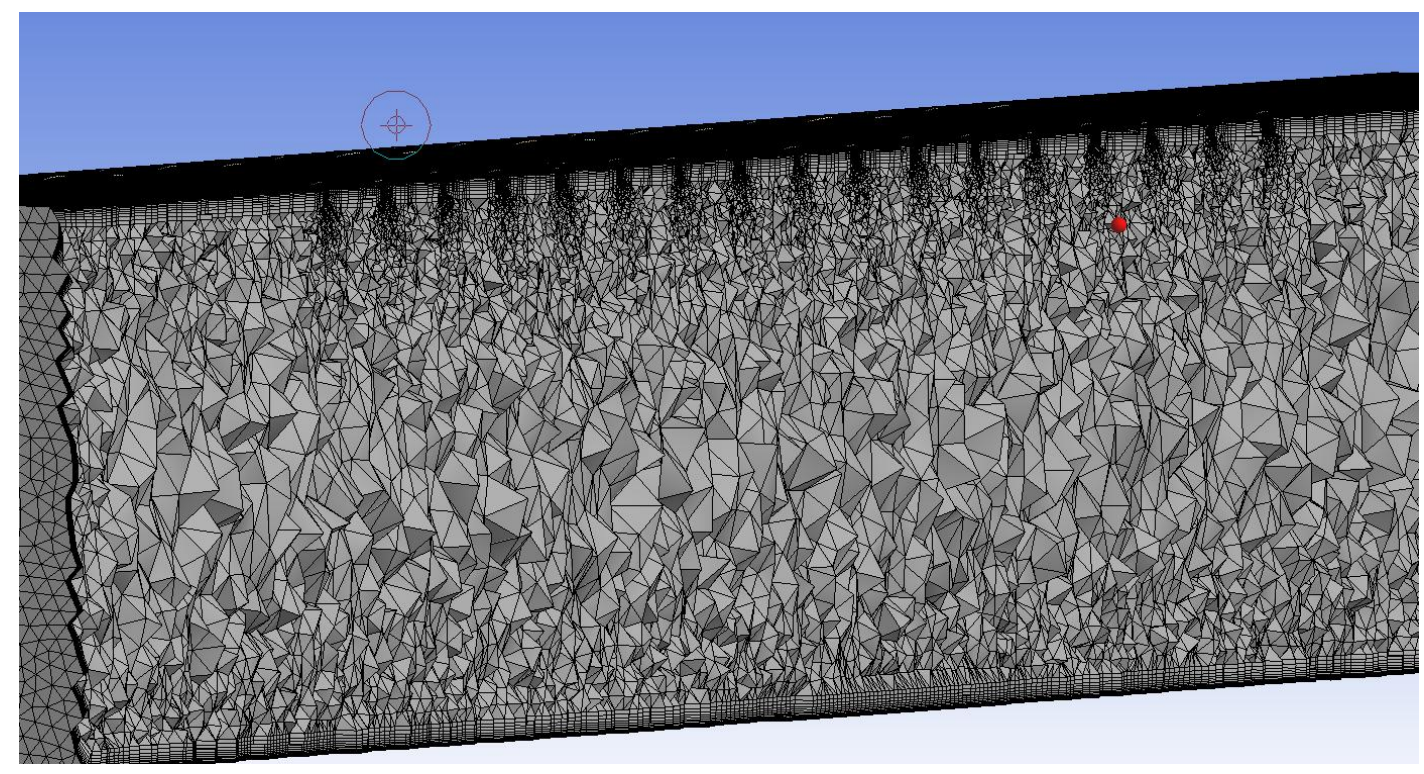

Figura 29 - Malha numérica da caixa sopradora. 
A Figura 30 mostra em detalhe a interface entre as três divisões feitas no modelo. A figura representa a malha na região de um orifício através de um corte longitudinal à caixa sopradora que passa pelo centro do orifício em questão. Podemos ver que nas regiões de interface entre as divisões as malhas são coincidentes, ou seja, não existiram erros de interpolação nos resultados quando se transporta uma propriedade entre as divisões analisadas.

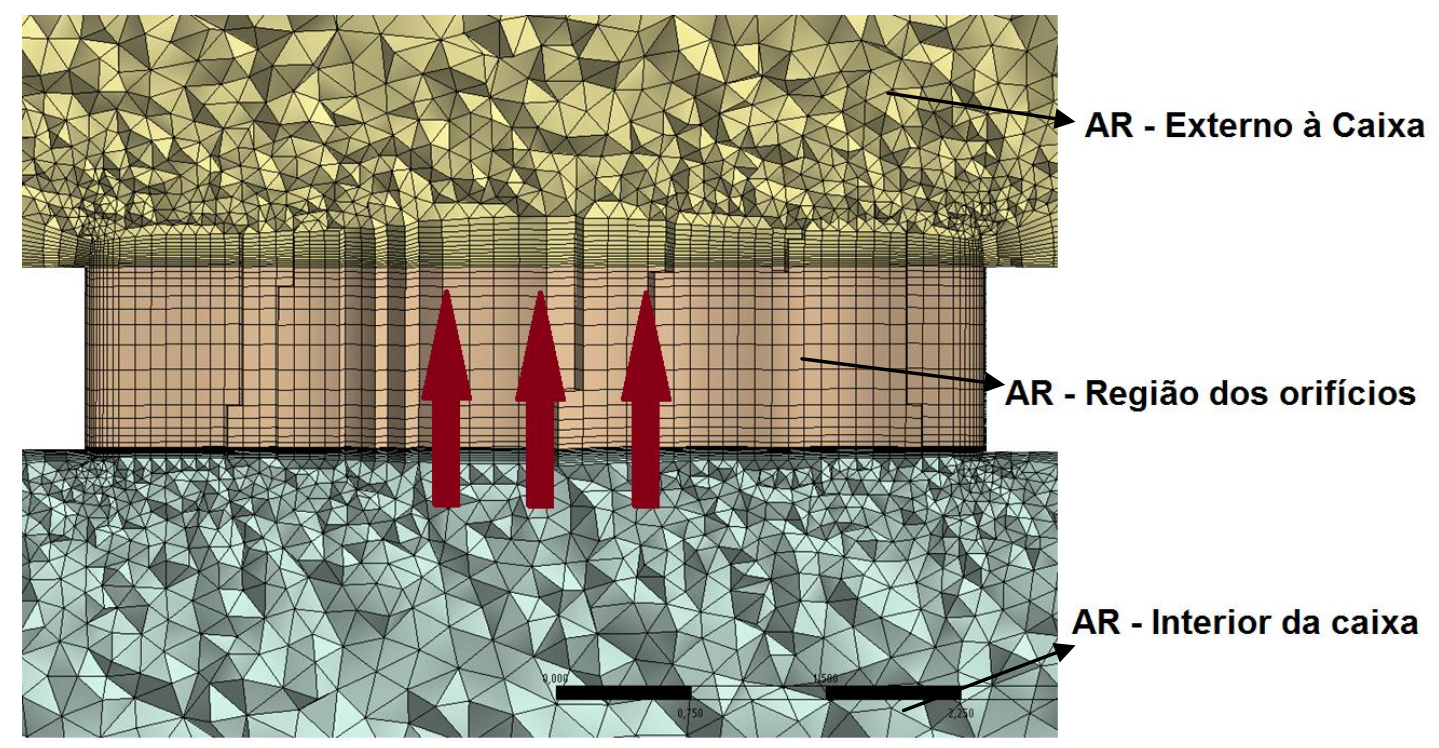

Figura 30 - Detalhe das malhas utilizadas na simulação numérica. Vista de detalhe das divisões criadas.

\subsubsection{Principais condições de contorno}

Para todos os modelos das caixas sopradoras, de maneira resumida, as principais condições de contorno relacionadas com os limites dos modelos analisados, podem ser observadas nas Figura 31, Figura 32 e Figura 33.

Para o na região interna à caixa sopradora, considera-se que o ar entra na caixa (através da face vermelha da Figura 32), as demais faces do ar interno, representa as chapas de aço da caixa sopradora. Para essas faces foi considerado condição de contorno do tipo parede. 
Para a região dos orifícios, as únicas faces presentes são referentes aos limites entre os orifícios e a chapa perfurada da caixa, nessas regiões considera-se também condição de contorno do tipo parede.

O ar externo à caixa sopradora foi modelado considerando-se que ao redor da caixa sopradora analisada existem outras caixas sopradoras.

Ou seja, considerando-se a Figura 31 existem 3 outras caixas sopradoras acima, abaixo e à esquerda da caixa sopradora analisada. Dessa maneira o ar externo foi modelado até a metade da distância entre caixas sopradoras.

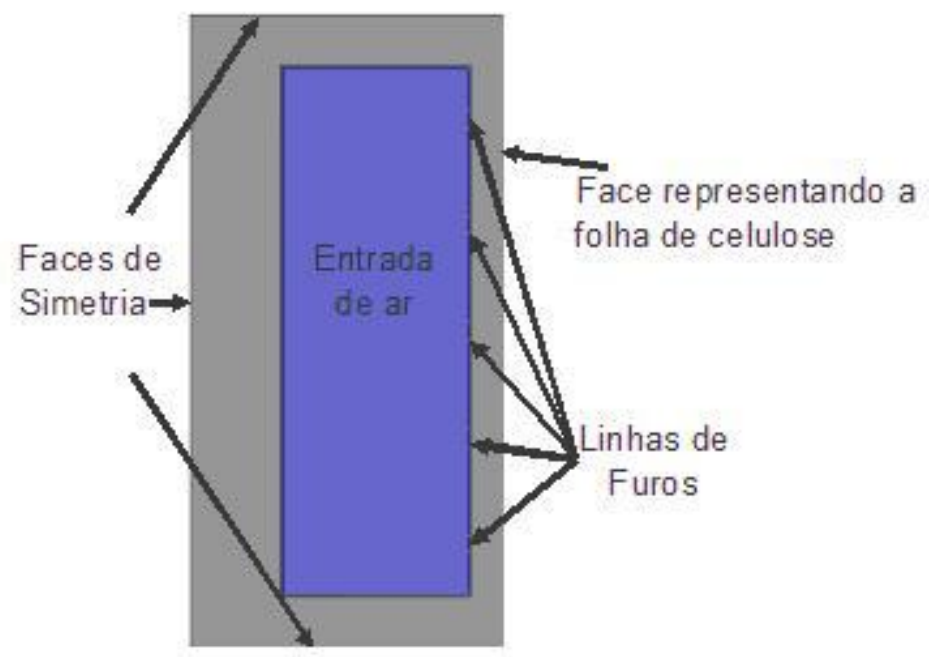

Figura 31 - Principais condições de contorno para a vista da caixa sopradora pela face de entrada do ar.

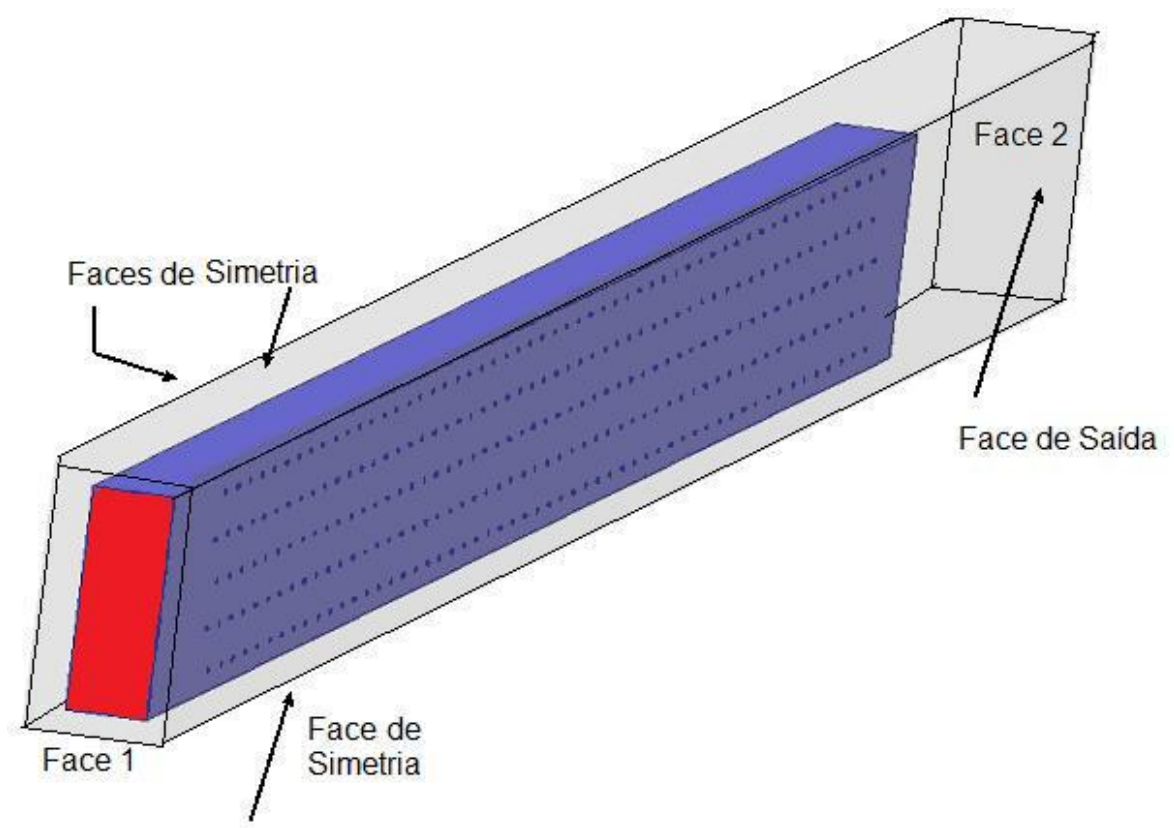

Figura 32 - Principais condições de contorno da caixa sopradora, vista isométrica. 
As distâncias consideradas, referentes ao posicionamento das demais caixas sopradoras foram:

- Caixa à esquerda: $200 \mathrm{~mm}$;

- Caixas acima e abaixo: $100 \mathrm{~mm}$;

- Distância para a folha de celulose: $20 \mathrm{~mm}$.

A Figura 33 mostra os limites do modelo, com relação às distâncias mencionadas, observando-se que os limites do modelo têm a metade das distâncias entre caixas.

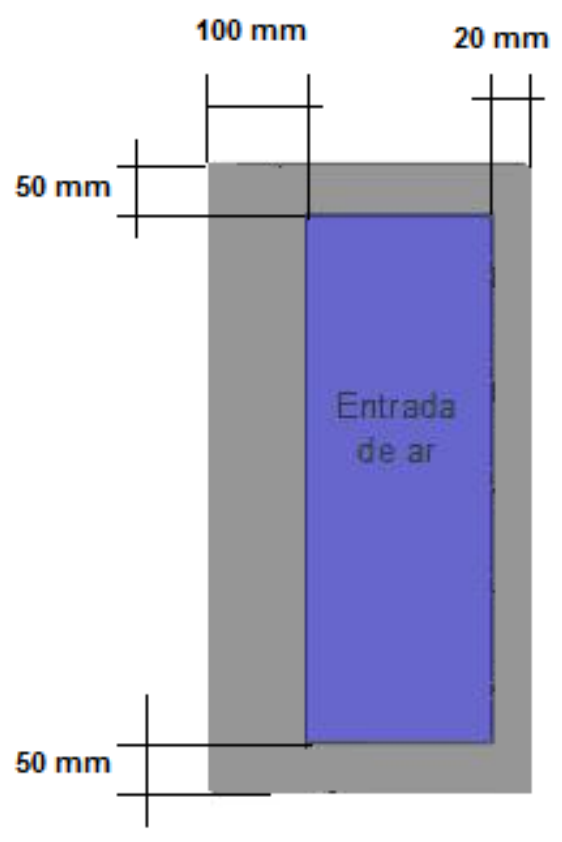

Figura 33 - Limites do modelo.

Para a região do ar externo à caixa sopradora, as faces que representam a metade da distância entre caixas sopradoras (verticalmente acima e abaixo e lateralmente em um dos lados), foram consideradas a condição de contorno do tipo simetria, conforme mostrado na Figura 31 e na Figura 32. 
Ainda para o ar externo, para a face que está voltada para a direção dos orifícios, o limite do modelo não é a metade da distância entre caixas e sim a distância total entre a caixa e a folha de celulose.

Nessa face considerou-se como condição de contorno do tipo parede móvel, com velocidade igual à $3 \mathrm{~m} / \mathrm{s}$, o que representa a velocidade da folha de celulose verticalmente, subindo ou descendo.

A face numeradas como 2 na Figura 32 elas correspondem à face de saída de ar do modelo, essa face é a única condição de contorno do tipo saída existente. Ela representa a região onde ocorre o tratamento do ar que acaba de receber umidade e perder temperatura após ser projetado contra a folha de celulose úmida.

O ar que escoa internamente à caixa sopradora é considerado como gás perfeito. Também foi considerada que $\mathrm{o}$ ar tivesse temperatura uniforme e constante durante toda a análise, com o valor de $140^{\circ} \mathrm{C}$.

Embora ocorra troca de calor e massa entre $\mathrm{o}$ ar e a folha de celulose, que provoca alteração na temperatura e umidade ao longo do escoamento, estas alterações não são avaliadas nesse estudo.

\subsection{Modelagem semi-empírica}

A determinação da geometria para uma caixa sopradora através de modelagem semi-empírica, também foi uma proposta investigada. Este modelo é estabelecido a partir da solução das equações integrais da energia e da continuidade, associadas à utilização de parâmetros empíricos relacionados às perdas de perdas de pressão que ocorrem no escoamento de ar que atravessa o duto e sai através de múltiplas saídas.

Um conjunto de hipóteses relacionadas ao escoamento de ar no interior da caixa e nas suas saídas é estabelecido para aplicação das equações como segue:

- Regime de escoamento é turbulento, permanente e incompressível; 
- Número de Reynolds: Re $\sim 10^{5}$;

- Escoamento no duto é completamente desenvolvido;

- Nas seções de entradas e saídas dos volumes de controle o perfil de velocidades é uniforme;

- Propriedades físicas do ar são invariantes.

Considera-se também que transversalmente ao escoamento de ar, no interior do duto analisado, a distribuição de ar é constante e a distribuição de ar nas múltiplas saídas do duto é uniforme.

O modelo considera como premissa a necessidade de balanceamento das vazões de ar, que devem sair do duto através das múltiplas saídas com mesmo valor. Ou seja, em cada seção transversal ao longo do comprimento do duto, em que há uma coluna de orifícios, haverá uma pressão interna que produzirá uma vazão de ar que atravessará estes furos. Na seção seguinte haverá uma nova pressão, que produzirá nas saídas laterais, dadas por nova coluna de orifícios, novamente a mesma vazão. E assim sucessivamente, até a última coluna de orifícios. Este é o princípio do balanceamento com vazões iguais em todas as saídas laterais.

A variação de pressão no sentido do escoamento dentro do duto é decorrente da soma das perdas distribuídas e localizadas que existem no movimento do ar. As perdas localizadas referem-se à presença dos orifícios de saída, onde temos uma perda de pressão devido à mudança da direção do escoamento de ar (saídas a 90) e outra perda causada por eventual expansão que ocorre no escoamento de ar que seguirá reto internamente ao duto. A perda distribuída ocorre devido ao atrito viscoso que ocorre no escoamento que segue em uma mesma direção e sentido, sem variações de áreas de seção transversal, nem influência de corpos inseridos no seu caminho.

O equacionamento semi-empírico foi aplicado em duas alternativas de caixas sopradoras. Um deles com seção transversal uniforme e outra com seção transversal variável.

As dimensões geométricas do modelo com seção transversal uniforme são: $C=5000 \mathrm{~mm} ; \mathrm{h}=300 \mathrm{~mm} ; \mathrm{L}=85 \mathrm{~mm}$. A disposição dos orifícios que 
formam as saídas laterais é de em 55 colunas de 5 orifícios. A vazão mássica na entrada é de $0,0855 \mathrm{~kg} / \mathrm{s}$ e a massa específica do ar é $0,75 \mathrm{~kg} / \mathrm{m}^{3}$.

A segunda alternativa, que tem como objetivo garantir a distribuição uniforme da vazão de ar através d os orifícios de saída lateral. Para tanto, o valor da largura, L, da caixa sopradora torna-se variável, assumindo um valor após cada uma das 55 colunas. Os valores de comprimento $C$, altura $h$, permanecem os mesmos. $O$ valor para a largura $L$ na primeira seção, entrada da caixa, é mantido como $L=85 \mathrm{~mm}$, o mesmo da caixa com seção transversal uniforme.

A formulação utilizando as equações integrais da energia e continuidade é simplificada pelas hipóteses apresentadas. Os coeficientes experimentais para as perdas são obtidos dos textos de Idelchik (2008) e Smacna (2006). Como não há nestas referências exatamente o presente caso, os coeficientes são obtidos por similaridade e interpolação entre casos semelhantes encontrados em Idelchik e SMACNA.

A equação da Energia na forma integral, em termos de pressão pode ser expressa conforme mostrado na equação 19. E a equação da continuidade, é apresentada na equação 20.

$$
\begin{gathered}
\int_{S C} \rho\left(\frac{v^{2}}{2}+\frac{P}{\rho}\right) \cdot \vec{v} \cdot \vec{n} \cdot \partial A=-\dot{W}_{\text {perdas }} \\
\int_{S C} \rho \cdot \vec{v} \cdot \vec{n} \cdot d A=0
\end{gathered}
$$

$\mathrm{Na}$ equação (19), a variável $\mathrm{W}_{\text {perdas }}$ representa as perdas singulares e perdas distribuídas associadas ao fluxo do ar, conforme já apresentado.

O acabamento superficial tipicamente obtido nas chapas que compõe a caixa sopradora internamente é suficiente para que se possa considerar o escoamento interno como hidraulicamente liso. Com esta condição, no diagrama de Moody, ou através de fórmulas empíricas pode-se determinar o coeficiente de perda distribuída ou fator de atrito, f. Para o número de Reynolds na seção de entrada da caixa assumindo o valor da ordem de $10^{5}$, o valor de $f$ é 0,018 . 
A obtenção do coeficiente de perda singular, $\zeta$, ré feita através da análise dos vários casos apresentados em Idelchik (2008), e opta-se pelo digrama 7-39. Considera-se com sendo um duto com 55 ramais e a perda associada às saídas laterais, pode ser calculada com o valor para $\zeta$ igual a 0,18 .

Para a expansão do escoamento após a saída de uma parcela do ar por uma coluna de orifícios, considerou-se $\zeta$ igual a 0,10 . Tal valor é obtido a partir de referência manual da Smacna (2006) na tabela A11, que também faz referência ao texto de Idelschik (2008).

Para a solução deste modelo é utilizada um planilha de cálculo na qual são considerados como dados de entrada a geometria da caixa e as condições físicas do ar. Nesta planilha o modelo é calculado com sua divisão em 55 volumes de controle, sendo que as fronteiras de cada volume de controle são compostas por uma coluna de orifícios e as faces internas da caixa sopradora contidas entre as seções de montante e de jusante da coluna de orifícios estudada. 


\section{RESULTADOS E DISCUSSÃO}

Os resultados obtidos estão separados pela geometria da caixa sopradora utilizada e a condição de vazão mássica aplicada. Conforme discutido anteriormente foram avaliadas duas alternativas de caixas sopradoras e cada uma dessas possibilidades foi analisada quanto a duas condições diferentes de vazão de ar na entrada da caixa sopradora. Tais condições se referiram a vazão nominal da caixa sopradora, e como mencionado anteriormente, uma vazão $30 \%$ superior à nominal.

Ressalta-se que o modelo de caixa sopradora com seção transversal variável apresenta seção transversal uniformemente variada, partindo-se da seção transversal idêntica à utilizada no modelo de seção transversal uniforme, até que fosse obtida a seção transversal reduzida a $30 \%$ no final da caixa sopradora.

Também foi modelada uma caixa sopradora de teste, idêntica a utilizada para a obtenção dos resultados experimentais (Figura 24). Tal modelo foi criado com o intuito de verificar os resultados numéricos obtidos por meio de comparação com os resultados experimentais.

\subsection{Caixa sopradora de teste}

Para o modelo da caixa sopradora de teste, a simulação numérica realizada adotou os seguintes parâmetros:

- Modelo de turbulência tipo $k-\varepsilon$, com elemento de malha nos tamanhos máximo de $0,5 \mathrm{~mm}$ para faces, parâmetro adimensional $\mathrm{y}^{+}$ com valores entre 11 e 100, malha prismática nas paredes com 20 camadas, sendo a primeira camada com $0,01 \mathrm{~mm}$ com taxa de crescimento de $10 \%$. 
Para o modelo em questão a malha computacional teve as seguintes características:

- Malha final com 17 milhões de células;

- $\quad$ Skewness máximo de 0,92;

- $\quad y^{+}$máximo igual a 15 ;

- $\quad$ Tempo de geração de malha de aproximadamente 15 horas;

- $\quad$ Fluido utilizado: Ar, considerado como gás perfeito;

- Temperatura do fluido: $140^{\circ} \mathrm{C}$ foi considerado que todo o modelo estivesse em equilíbrio térmico nesta temperatura;

- Vazão mássica na entrada: 0,0058 kg/s;

- $\quad$ Pressão estática média na face de saída do modelo: -150 Pa;

- Massa específica do fluido: $0,75 \mathrm{~kg} / \mathrm{m}^{3}$, como os valores máximos de velocidade encontrada estão abaixo de 0,3 do número de Mach, foi considerado que o fluido como incompressível (Versteeg, Malalasekera, 1995);

- $\quad$ Número de Reynolds na seção de entrada da caixa sopradora: 4322;

- $\quad$ Número de Reynolds médio nos jatos de ar: 5013.

Como critérios de convergência, definiu-se como sendo os resíduos das equações da conservação quantidade de movimento e da conservação de massa, inferiores a $10^{-5}$.

A simulação numérica foi feita em uma estação de trabalho, com oito núcleos para o processamento computacional e 16 gigabytes de memória RAM, para atingir os critérios de convergência foram necessárias aproximadamente 80 horas.

A velocidade média de saída do ar pelos orifícios da caixa sopradora de teste foi de $30,6 \mathrm{~m} / \mathrm{s}$. A distribuição da velocidade na região de um orifício pode ser observada na Figura 34, ressaltando-se que devido ao sistema de coordenadas utilizado, a direção u negativa representa a direção do jato de ar na saída do orifício. 


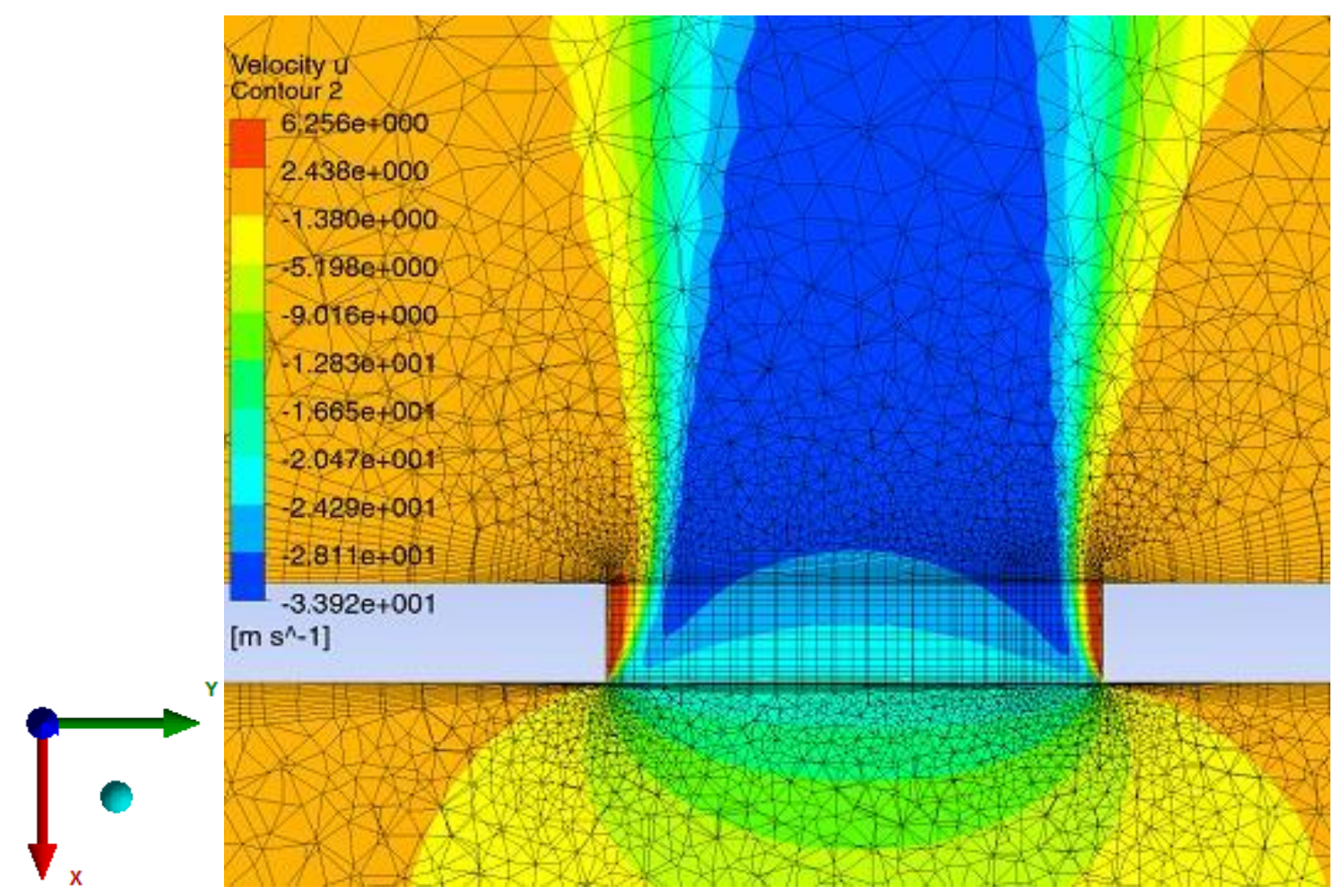

Figura 34 - Valores de velocidade da saída do ar para a caixa sopradora de teste.

A Figura 35 mostra o efeito da contração do jato de ar na região da saída de um dos orifícios. A região em cinza, próxima do orifício, indica fluxo de ar na direção positiva de u, ou seja, na direção contrária ao jato de ar no orifício, causando a contração do jato.

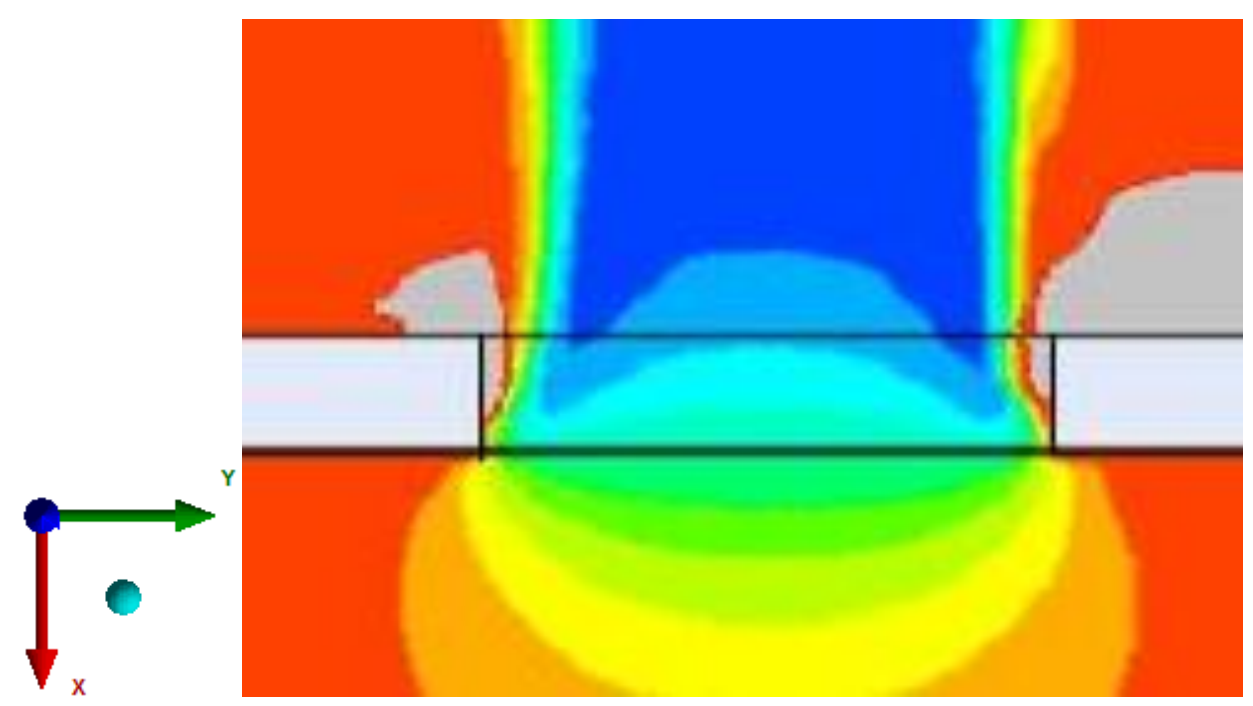

Figura 35 - Detalhe da contração jato para a caixa sopradora de teste. 
A Figura 36 mostra a diferença entre as pressões internas e externas em um plano longitudinal da caixa sopradora de teste. A diferença de pressão total obtida foi de $345,8 \mathrm{~Pa}$.

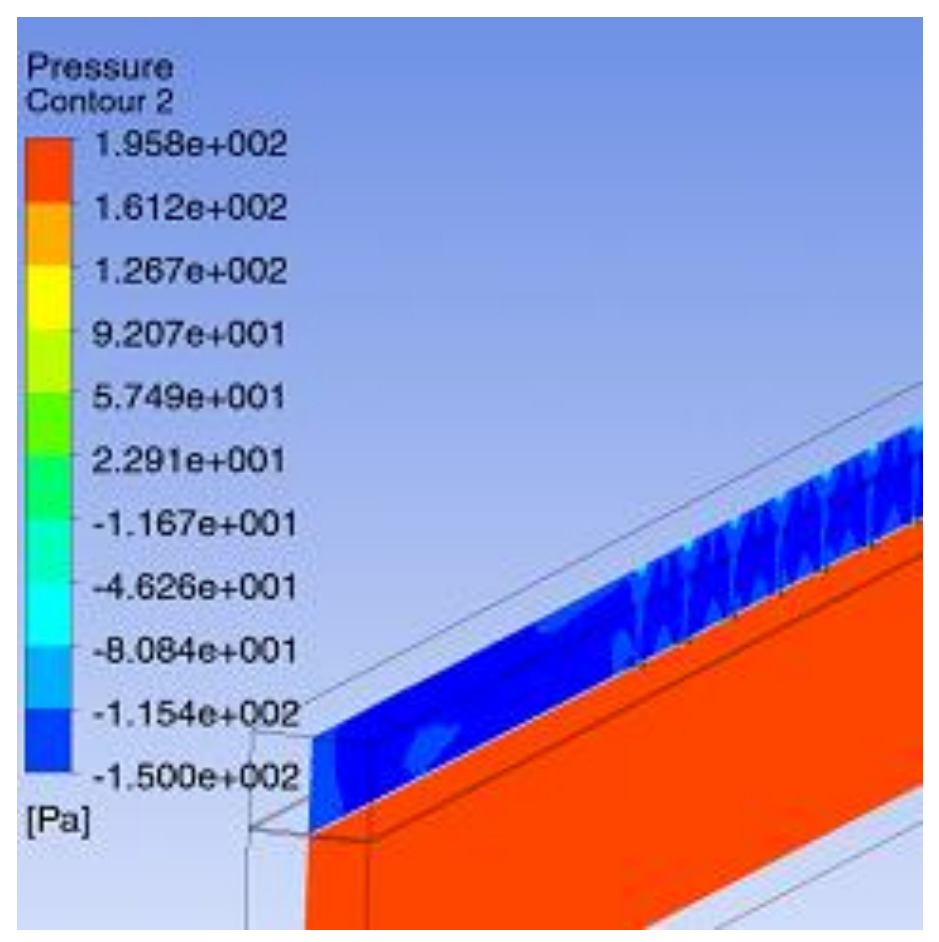

Figura 36 - Valores de pressões para a caixa sopradora de teste.

Os resultados obtidos experimentalmente mostraram que para a caixa sopradora de teste, a velocidade média de saída foi de $30 \mathrm{~m} / \mathrm{s}$, enquanto as medições de pressão indicavam uma diferença de pressão total de $350 \mathrm{~Pa}$.

Tais resultados experimentais indicam que os valores numéricos e experimentais estão próximos. Os valores de variação da pressão também apresentaram bastante proximidade entre as simulações numéricas e os resultados experimentais.

Desta maneira assumiu-se que há correspondência entre as simulações numéricas e o escoamento real. Também é assumido que devido às similaridades existentes entre os modelos ensaiados experimentalmente e os modelos reais da caixa sopradora, as simulações numéricas que representaram os modelos reais da caixa sopradora também terão correspondência com os fluxos de ar que existirão nas caixas sopradoras reais. 
Por se tratar de uma inovação técnica, não existem até o momento dados referentes ao comportamento real das caixas sopradoras que confirmem ou refutem a hipótese de que os dados numericamente obtidos têm correlação com o fluxo real de ar nas caixas sopradoras.

\subsection{Caixa sopradora de seção transversal uniforme}

Para a caixa sopradora de seção transversal uniforme, foram realizadas simulações com os seguintes parâmetros:

- Modelo de turbulência tipo k-e, com elemento de malha nos tamanhos máximo de $3 \mathrm{~mm}$ para faces, parâmetro adimensional $\mathrm{y}^{+}$ com valores entre 50 e 100, malha prismática nas paredes com 10 camadas, primeira camada com $0,5 \mathrm{~mm}$ com taxa de crescimento de $25 \%$;

Outros parâmetros geométricos de malha também foram levados em consideração, tais como a assimetria (do inglês skewness) cujos valores encontrados foram sempre menores que 0,96 .

Um dos parâmetros, acima mencionados, avaliado na comparação das dimensões dos elementos de malha foi o adimensional $\mathrm{y}^{+}$, que é uma função de parede que caracteriza a região da camada limite em que estão posicionados os nós.

De acordo com recomendações da ANSYS os valores de $\mathrm{y}^{+}$devem estar entre os limites de 30 e 500, para o caso de se utilizar o modelo k- $\varepsilon$. Essa faixa existe para que a interação entre o fluido e a parede, durante o processamento do software, possa ser representada adequadamente.

Para o modelo em questão a malha computacional teve as seguintes características finais:

- Malha final com 21 milhões de células;

- $\quad$ Skewness máximo de 0,92;

- $\quad$ Tempo de geração de malha de aproximadamente 4 horas; 
- Fluido utilizado: Ar, considerado como gás perfeito;

- Temperatura do fluido: $140^{\circ} \mathrm{C}$ foi considerado que todo o modelo estivesse em equilíbrio térmico nesta temperatura;

- Vazão mássica na entrada: 0,0855 kg/s e 0,1112 kg/s;

- Pressão estática média na face de saída do modelo: -150 Pa;

- Massa específica do fluido: $0,75 \mathrm{~kg} / \mathrm{m}^{3}$, como os valores máximos de velocidade encontrada estão abaixo de 0,3 do número de Mach, foi considerado que o fluido como incompressível (Versteeg, Malalasekera, 1995).

Como critérios de convergência definiu-se como sendo os resíduos das equações da conservação quantidade de movimento e da conservação de massa, inferiores a $10^{-4}$.

A simulação numérica foi feita em uma estação de trabalho, com oito núcleos para o processamento computacional e 16 gigabytes de memória RAM, para atingir os critérios de convergência foram necessárias aproximadamente 90 horas, para o modelo com vazão de ar nominal e de aproximadamente 96 horas para o modelo com vazão 30\% superior a vazão nominal.

A Tabela 1 mostra o número de Reynolds para as condições de vazão de ar consideradas em duas regiões da caixa sopradora. O primeiro refere-se ao número de Reynolds na entrada da caixa sopradora e foi estimado utilizando o diâmetro equivalente da seção transversal da caixa sopradora e a velocidade de entrada do ar na caixa sopradora. O segundo refere-se ao número de Reynolds na região dos jatos de ar e foi estimado com o diâmetro dos orifícios e considerando-se a média das velocidades médias na região dos orifícios. 
Tabela 1 - Número de Reynolds para os modelos de caixa sopradora com seção transversal uniforme

\begin{tabular}{l|cc}
\hline Região analisada & $\begin{array}{c}\text { Número de Reynolds } \\
\text { para vazão nominal }\end{array}$ & $\begin{array}{c}\text { Número de Reynolds para } \\
\text { vazão 30\% superior }\end{array}$ \\
\hline $\begin{array}{l}\text { Entrada da caixa } \\
\text { sopradora }\end{array}$ & 25014 & 32557 \\
$\begin{array}{l}\text { Região dos jatos de } \\
\text { ar }\end{array}$ & 5407 & 6996 \\
\hline
\end{tabular}

A média das velocidades médias de saída do ar pelos orifícios da caixa sopradora são mostradas na Figura 37 e Figura 38. 


\section{Gráfico Velocidade Jato x Furo}

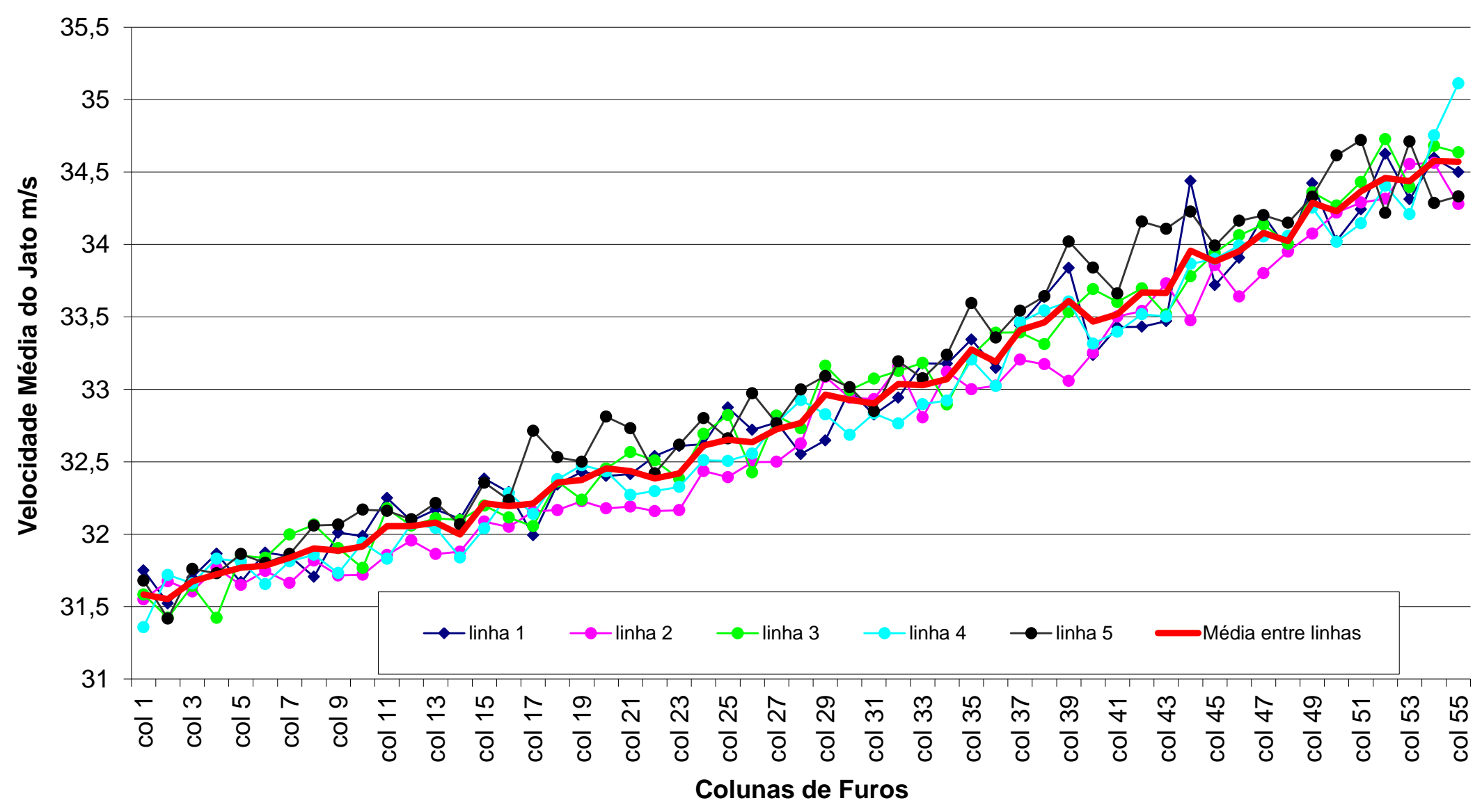

Figura 37 - Velocidade Jato x Orifício - Caixa sopradora seção uniforme e vazão nominal. 


\section{Gráfico Velocidade Jato x Orifícios}

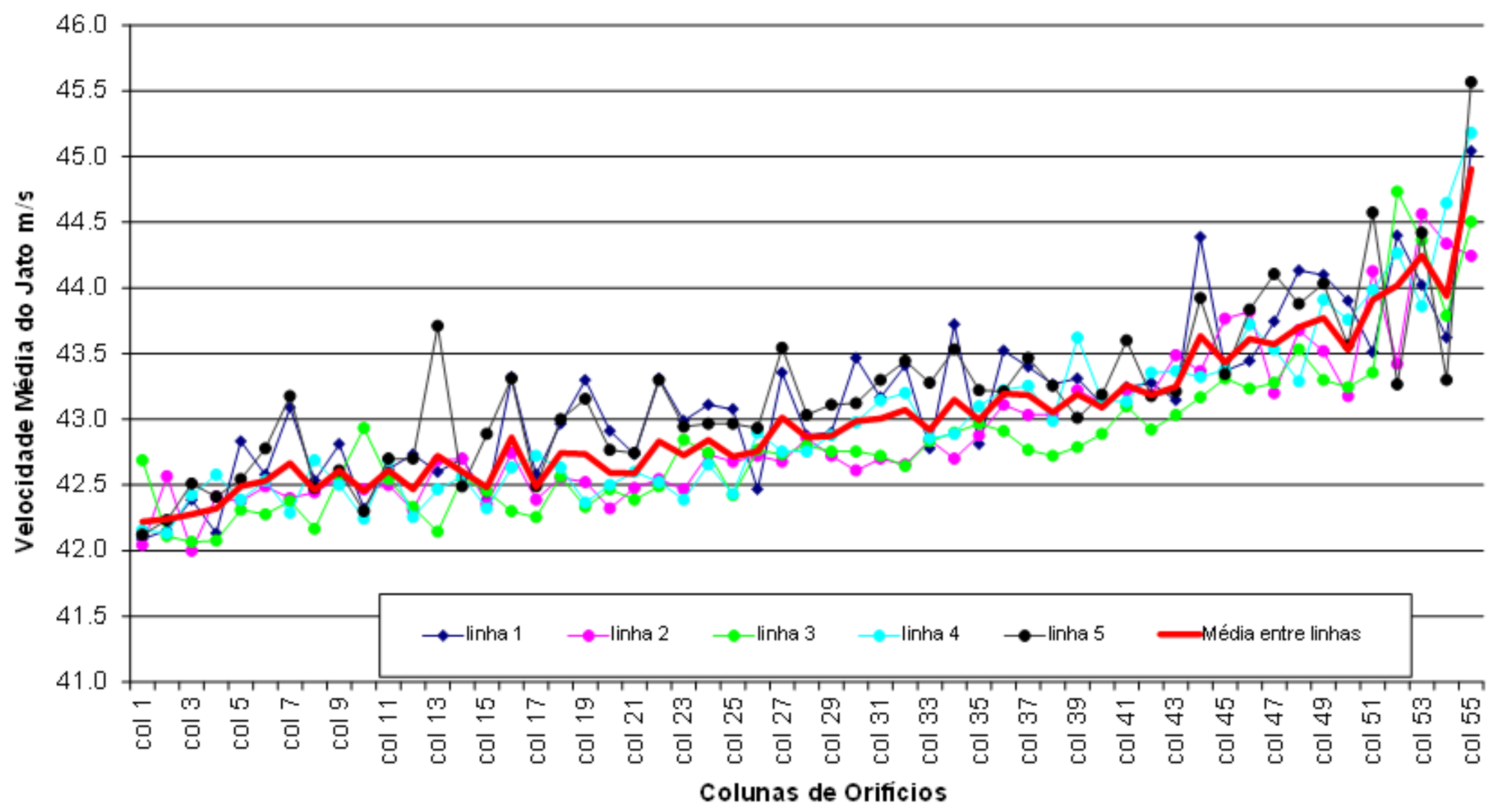

Figura 38 - Velocidade Jato x Orifício - Caixa sopradora seção uniforme e vazão 30\% maior que a nominal 
Para a melhor compreensão da distribuição geométrica dessas velocidades agruparam-se os dados da seguinte maneira: 5 linhas de orifícios (referentes às 5 linhas de orifícios existentes) e 55 colunas de orifícios (referentes à direção do fluxo de ar dentro da caixa sopradora).

Também foi adicionada uma linha no gráfico referente à velocidade média do jato de ar para a mesma coluna, ou seja, a média entre os 5 valores das linhas de orifícios para cada coluna.

A observação dos dados permite concluir que a vazão de ar por orifício da caixa vai aumentando na direção do fluxo de ar interno à caixa, ou seja, próximo da alimentação da caixa temos as velocidades mais baixas, assim como mais próximos ao final da caixa encontramos os maiores valores de velocidade média de saída.

No modelo com vazão mássica nominal a média das velocidades médias dos jatos foi de $32,9 \mathrm{~m} / \mathrm{s}$ com um desvio padrão de $0,9 \mathrm{~m} / \mathrm{s}$. Tal desvio padrão representa uma variação de 5,4\%. Já para o modelo com vazão mássica $30 \%$ maior que a nominal a média das velocidades médias foi de $42,7 \mathrm{~m} / \mathrm{s}$ com desvio padrão de $0,6 \mathrm{~m} / \mathrm{s}(2,6 \%)$.

A Figura 39 e a Figura 40 mostram a distribuição de pressões na caixa sopradora e Figura 41 e alguns vetores de velocidade na saída dos orifícios da caixa sopradora. A diferença de pressão encontrada nos dois modelos foi de $528 \mathrm{~Pa}$ para o modelo com vazão nominal e de $1110 \mathrm{~Pa}$ para o modelo com vazão mássica $30 \%$ maior que a nominal. 


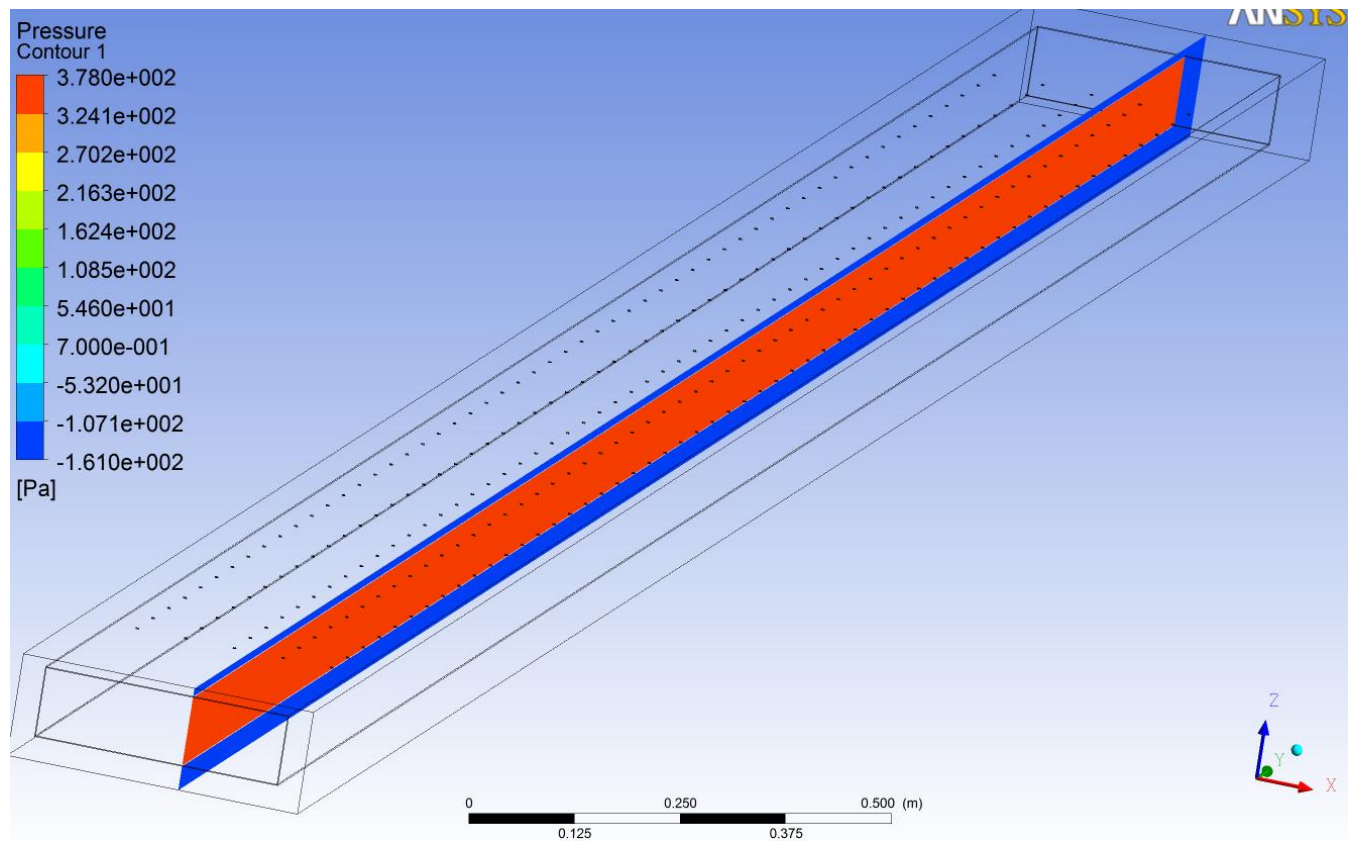

Figura 39 - Variação de pressão no interior da caixa sopradora - Modelo com vazão nominal.

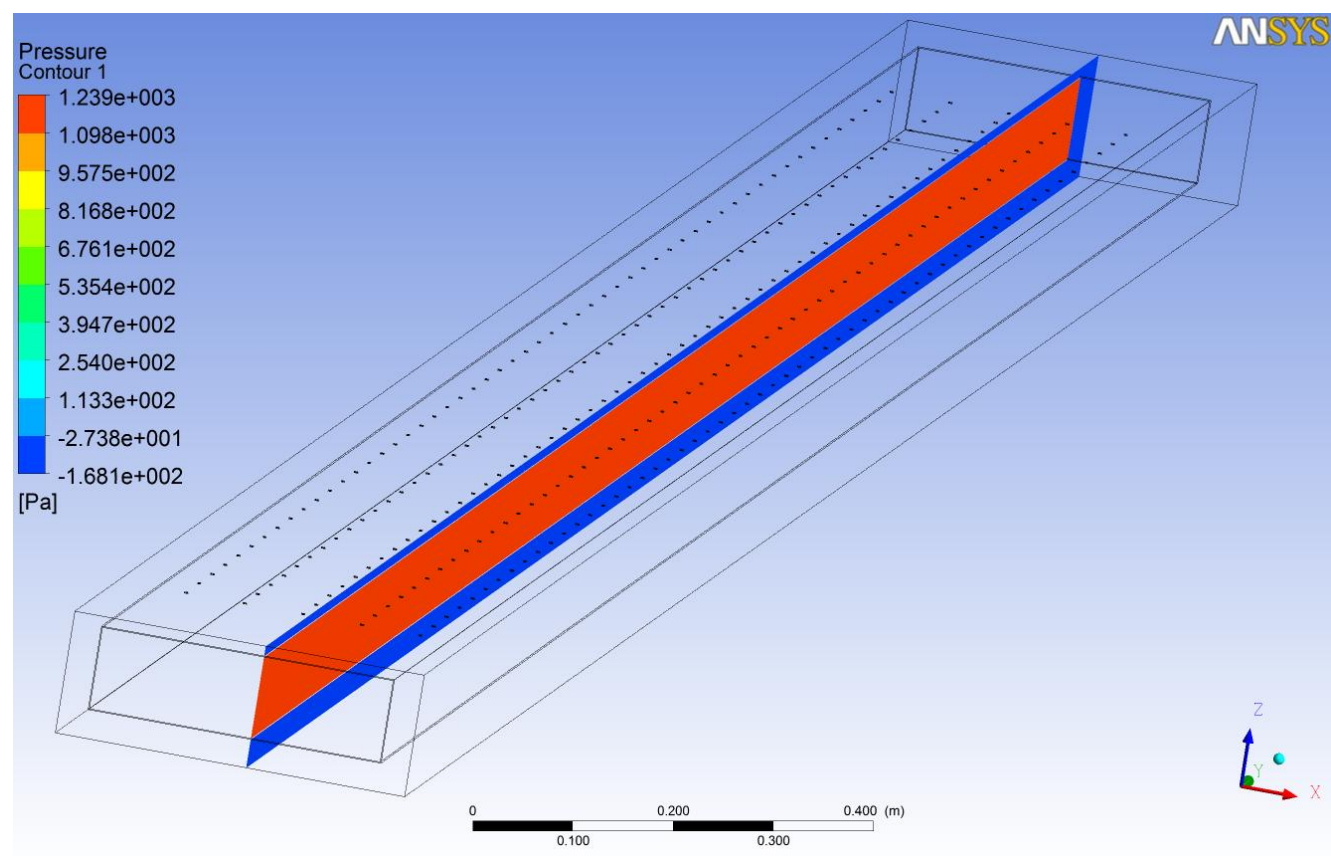

Figura 40 - Variação de pressão no interior da caixa sopradora - Modelo com vazão $30 \%$ superior à nominal. 


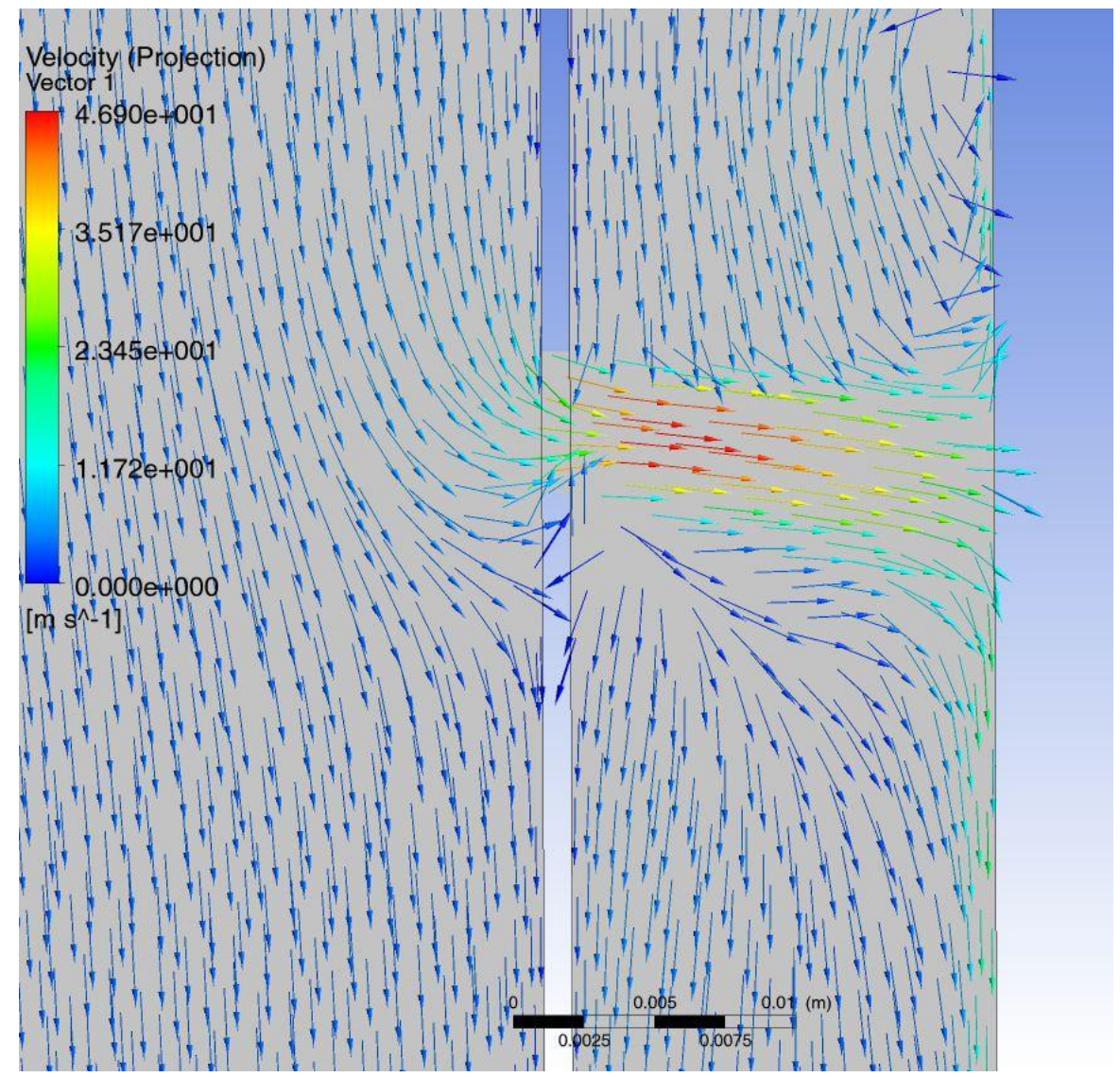

Figura 41 - Vetores de velocidade na região dos orifícios.

\subsection{Caixa sopradora de seção transversal variável}

Para o modelo de caixa sopradora de seção transversal variável, as mesmas considerações do modelo de seção transversal uniforme podem ser consideradas, apenas com relação à malha, os valores obtidos foram diferentes. Os novos valores foram:

- $\quad$ Malha final com 22 milhões de células;

- $\quad$ Skewness máximo de 0,94;

- $\quad$ Tempo de geração de malha de aproximadamente 4 horas;

- Temperatura do fluido: $140^{\circ} \mathrm{C}$, foi considerado que todo o modelo estivesse em equilíbrio térmico nesta temperatura;

- Vazão mássica na entrada: 0,0855 kg/s e 0,1112 kg/s; 
- $\quad$ Pressão estática média na face de saída do modelo: -150 Pa;

- $\quad$ Massa específica do fluido: $0,75 \mathrm{~kg} / \mathrm{m}^{3}$, como os valores máximos de velocidade encontrada estão abaixo de 0,3 do número de Mach, foi considerado que o fluido como incompressível (Versteeg, Malalasekera, 1995).

Como critérios de convergência definiu-se como sendo os resíduos das equações da conservação quantidade de movimento e da conservação de massa, inferiores a $10^{-4}$.

A simulação numérica foi feita em uma estação de trabalho, com oito núcleos para o processamento computacional e 16 gigabytes de memória RAM, para atingir os critérios de convergência foram necessárias aproximadamente 90 horas, para o modelo com vazão de ar nominal e de aproximadamente 80 horas para o modelo com vazão $30 \%$ superior a vazão nominal.

A Tabela 2 mostra o número de Reynolds para as condições de vazão de ar consideradas em duas regiões da caixa sopradora. O primeiro refere-se ao número de Reynolds na entrada da caixa sopradora e foi estimado utilizando o diâmetro equivalente da seção transversal da caixa sopradora e a velocidade de entrada do ar na caixa sopradora. O segundo refere-se ao número de Reynolds na região dos jatos de ar e foi estimado com o diâmetro dos orifícios e considerando-se a média das velocidades médias na região dos orifícios.

Tabela 2 - Número de Reynolds para os modelos de caixa sopradora de seção transversal variável

\begin{tabular}{l|cc}
\hline Região analisada & Vazão nominal & Vazão $30 \%$ superior \\
\hline $\begin{array}{l}\text { Entrada da caixa } \\
\text { sopradora }\end{array}$ & 25014 & 32557 \\
$\begin{array}{l}\text { Região dos jatos } \\
\text { de ar }\end{array}$ & 5372 & 6980 \\
\hline
\end{tabular}

A média das velocidades médias de saída do ar pelos orifícios da caixa sopradora são mostradas na Figura 42 e na Figura 43 


\section{Gráfico Velocidade Jato x Orifícios}

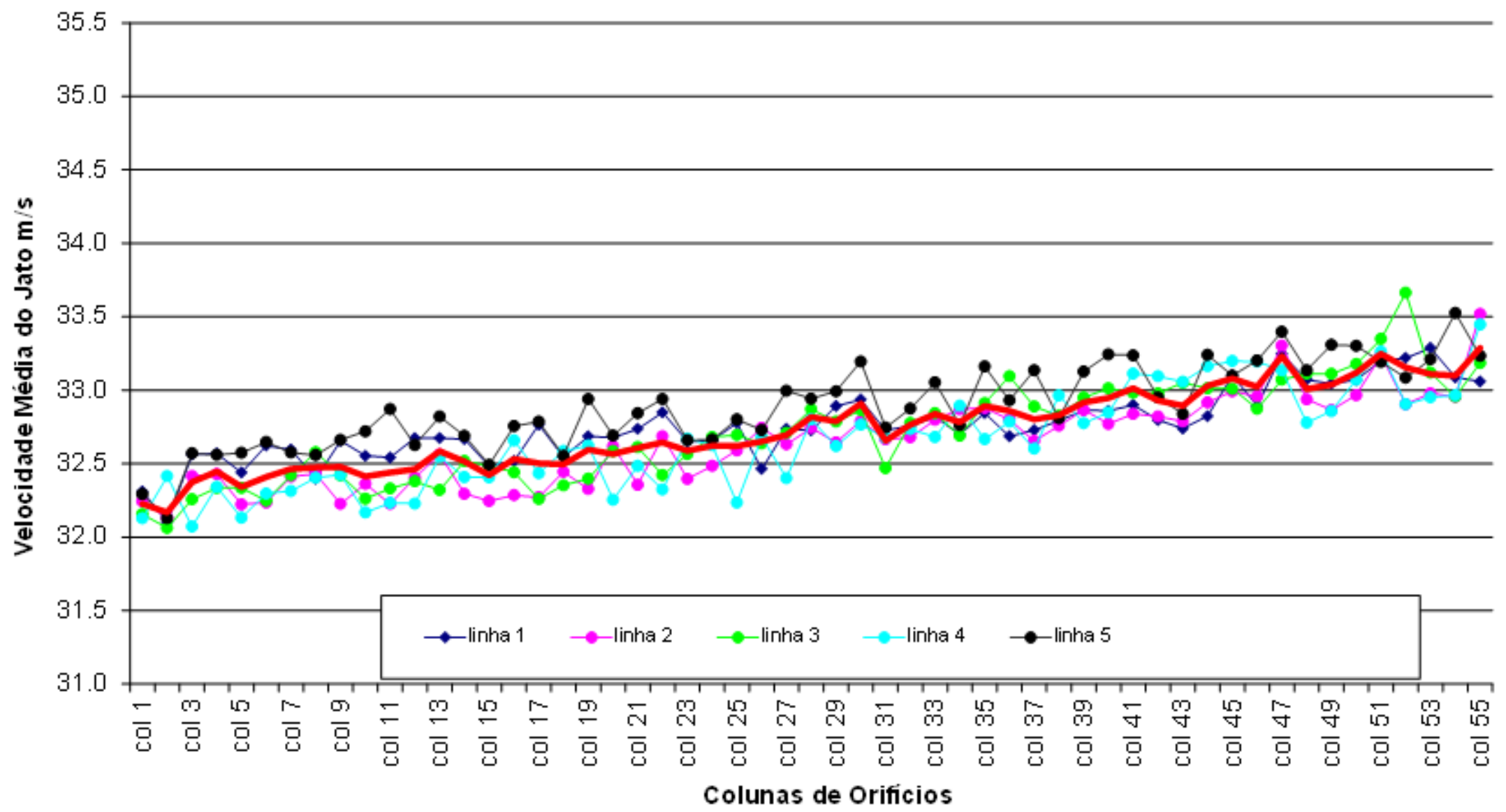

Figura 42 - Velocidade Jato x Orifício - Caixa sopradora de seção transversal variável e vazão nominal. 


\section{Gráfico Velocidade Jato x Orifícios}

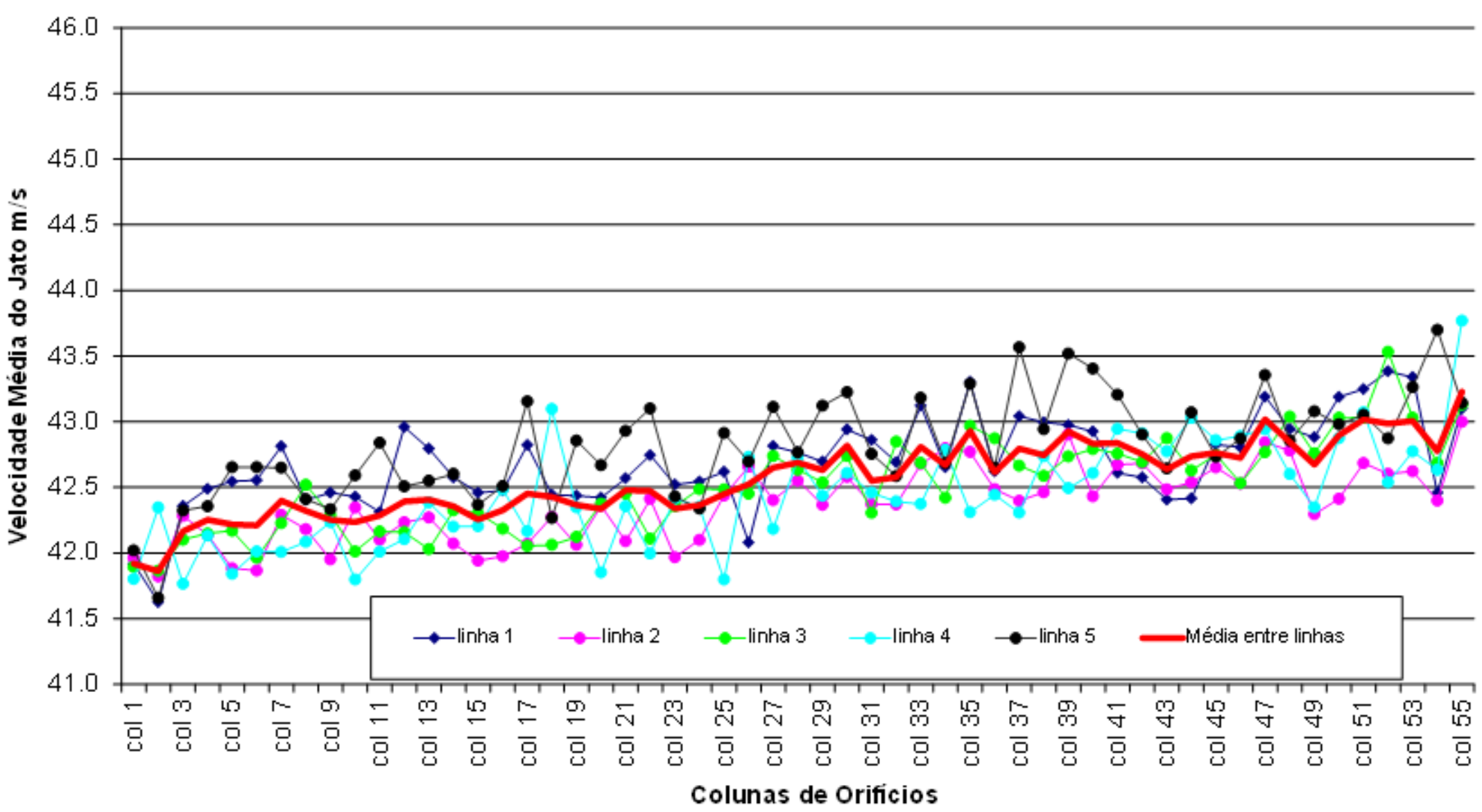

Figura 43 - Velocidade Jato x Orifício - Caixa sopradora seção transversal variável e vazão 30\% superior que a nominal. 
Da mesma maneira que para a caixa sopradora de seção uniforme, os dados também foram organizados por linhas e colunas, e da mesma maneira uma linha média (vermelha) foi adicionada.

A observação dos dados permite concluir que a vazão de ar por orifício da caixa vai aumentando na direção do fluxo de ar interno à caixa, ou seja, próximo da alimentação da caixa temos as velocidades mais baixas, assim como mais próximos ao final da caixa encontramos os maiores valores de velocidade média de saída.

Comparando-se com o modelo de seção uniforme vemos que os valores obtidos são sensivelmente mais uniformes do que no modelo anterior, principalmente para o caso com vazão mássica nominal. Neste caso, a média das velocidades médias de saída foi de $32,79 \mathrm{~m} / \mathrm{s}$ com um desvio padrão de $0,3 \mathrm{~m} / \mathrm{s}$. Tal desvio padrão representa uma variação de $1,8 \%$. Já para o modelo com vazão mássica $30 \%$ superior à nominal a média das velocidades médias de saída foi de $42,6 \mathrm{~m} / \mathrm{s}$ com um desvio padrão de $0,3 \mathrm{~m} / \mathrm{s}(1,4 \%)$.

A Figura 44 e a Figura 45 mostram a distribuição de pressões na caixa sopradora e Figura 46 mostra alguns vetores de velocidade na saída dos orifícios da caixa sopradora. A variação de pressão encontrada nos dois modelos foi de 500 Pa para o modelo com vazão nominal e de 1120 Pa para o modelo com vazão mássica $30 \%$ maior que a nominal. 


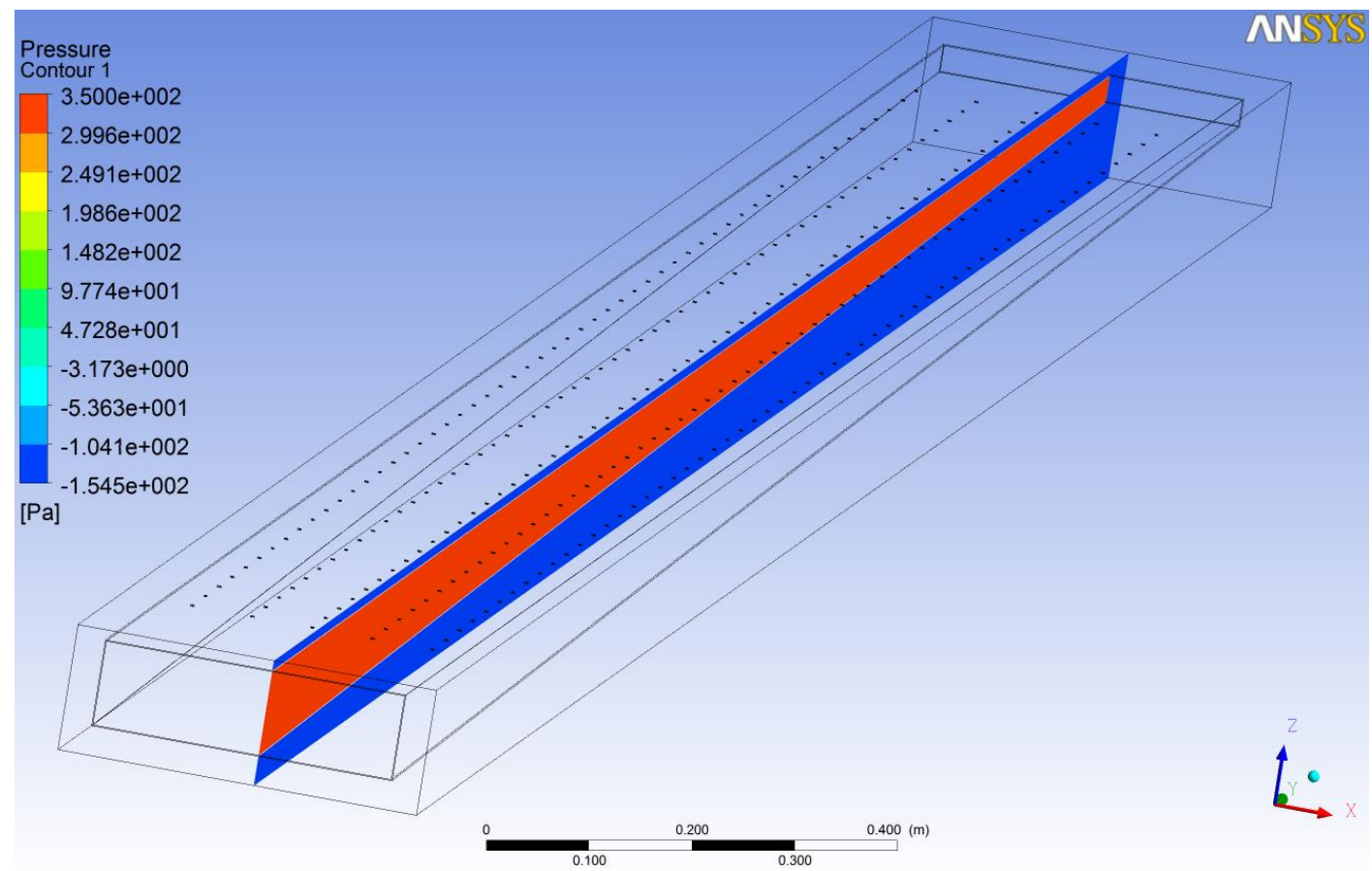

Figura 44 - Variação de pressão no interior da caixa sopradora - Modelo com vazão nominal.

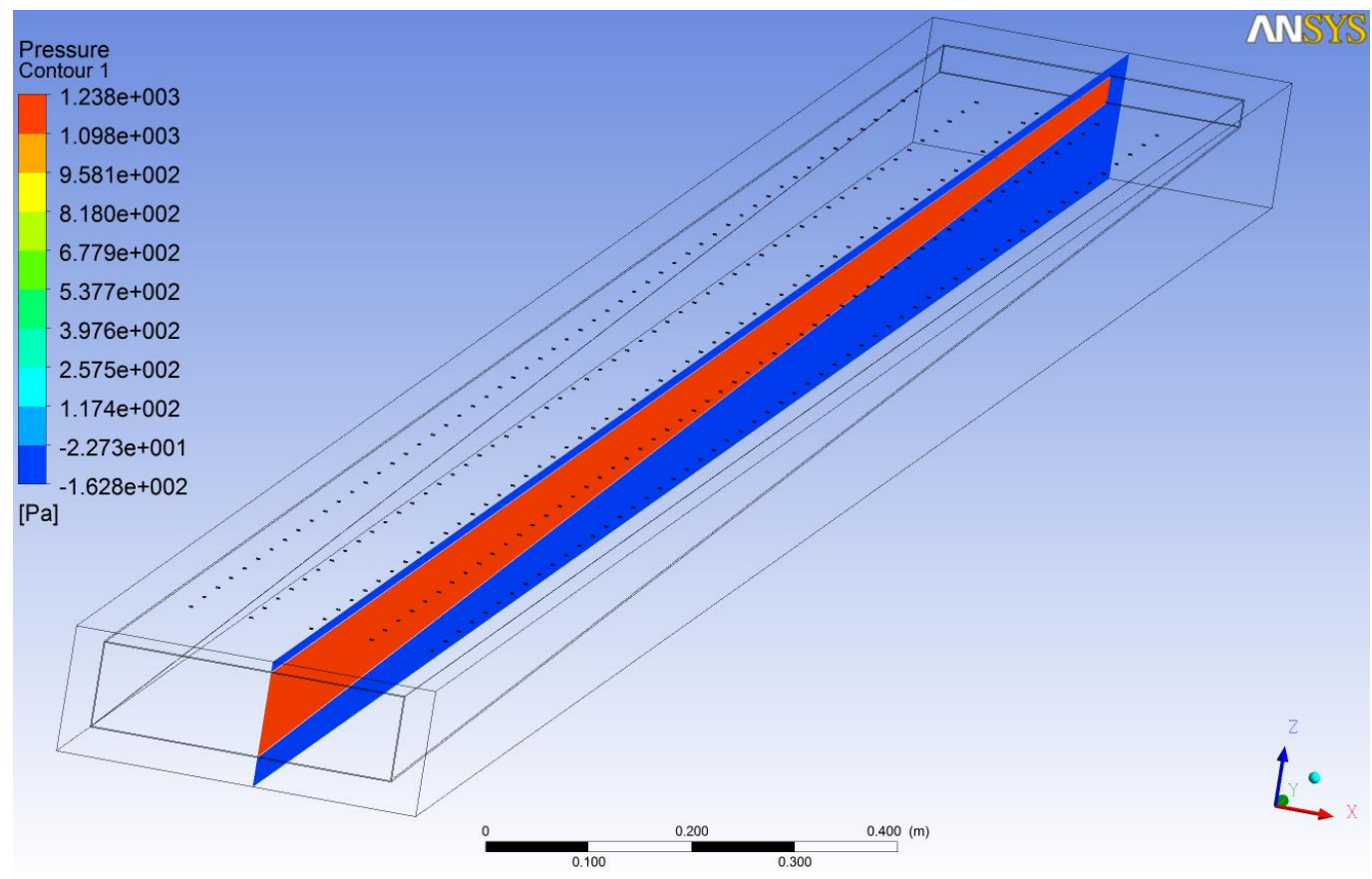

Figura 45 - Variação de pressão no interior da caixa sopradora - Modelo com vazão $30 \%$ superior à nominal. 


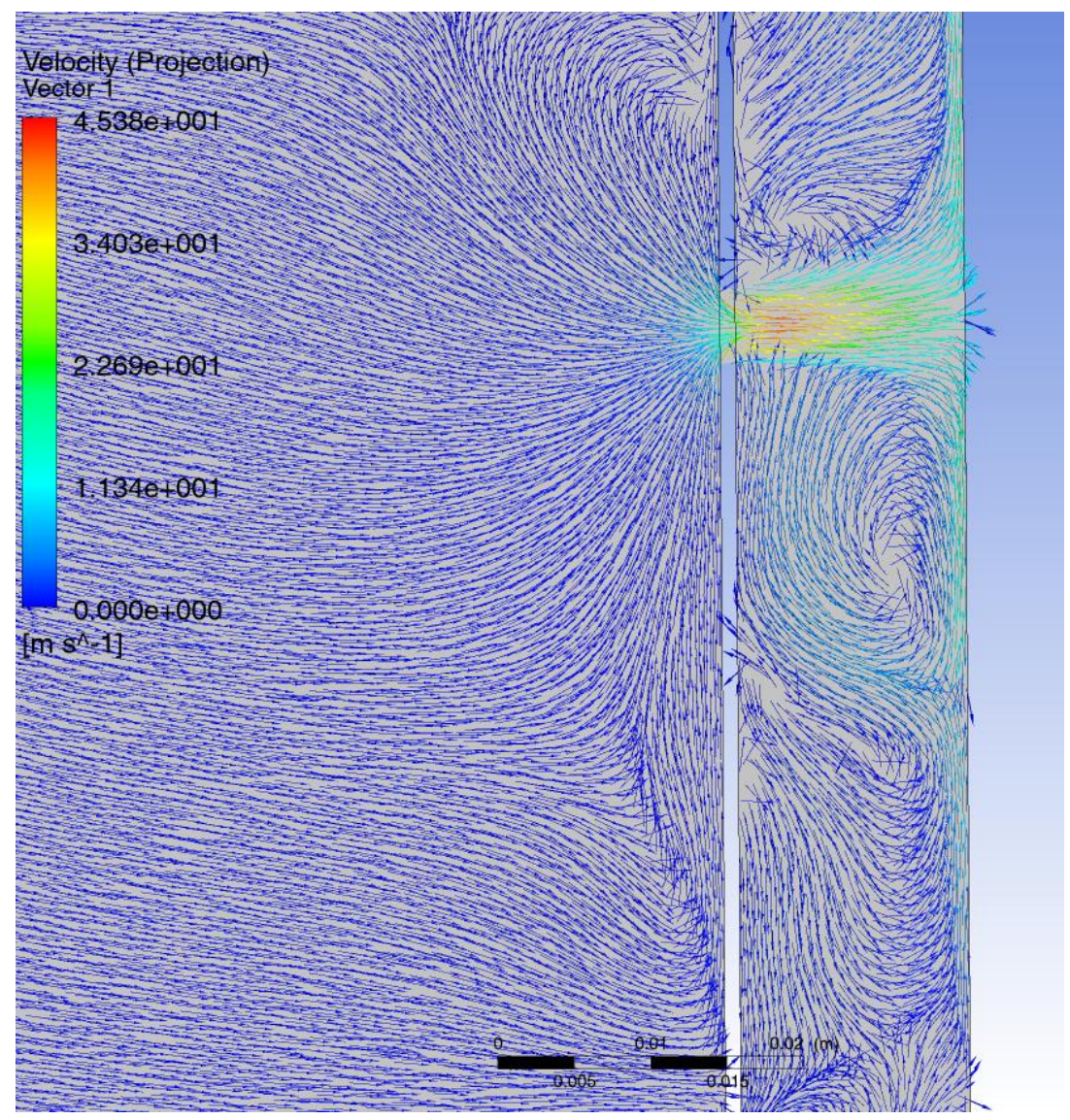

Figura 46 - Vetores de velocidade na região dos orifícios.

\subsection{Resultados do modelo semi-empírico}

Os resultados que são exibidos foram obtidos com a adoção de parâmetros empíricos provenientes da literatura.

Para que se pudessem analisar os efeitos das perdas existentes no escoamento, oriundos de coeficientes de perdas (distribuídas e localizadas) foram calculadas dois casos distintos. O primeiro desconsiderando as perdas existentes no escoamento e o segundo considerando-as.

Também foi considerado que a vazão mássica de ar fosse 0,0855 kg/s, a massa específica considerada $0,75 \mathrm{~kg} / \mathrm{m}^{3}$ e a caixa sopradora teria 55 colunas de orifícios com $4 \mathrm{~mm}$ de diâmetro cada, sendo consideradas 5 linhas de orifícios por coluna, ou seja, a mesma disposição adotada nas simulações numéricas. 
Elaborou-se uma planilha de cálculo para a solução do sistema de equações proposto. Para o modelo sem perdas considerou-se que a pressão seria constante no interior da caixa sopradora.

A pressão externa foi considerada igual a pressão ambiente e a velocidade de saída em cada orifício constante.

\subsubsection{Modelo semi-empírico - sem perdas}

Para a distribuição uniforme do ar, entre os orifícios presentes na caixa sopradora e desconsiderando-se as perdas, a Figura 47 mostra a variação da seção largura da caixa sopradora, necessária para que essa distribuição uniforme do ar ocorresse.

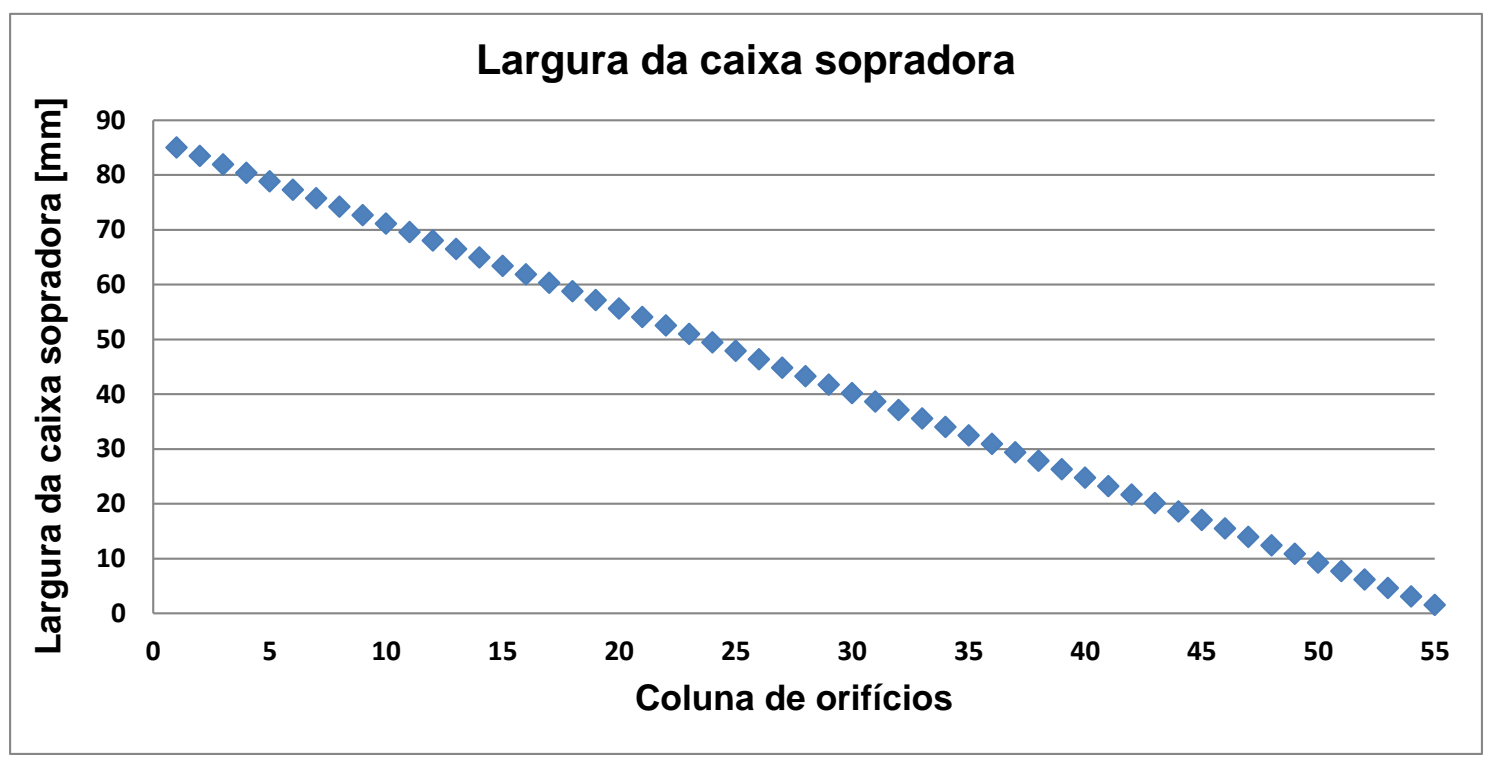

Figura 47 - Variação da largura da caixa sopradora em função das colunas de orifícios.

Neste caso, análise sem perdas, a pressão da no interior da caixa sopradora se mantém constante, sendo que a pressão interna calculada foi de 400,6 Pa.

Ou seja, os resultados mostrados apontam para uma redução da seção transversal de $98 \%$, partindo de $85 \mathrm{~mm}$ até $1,5 \mathrm{~mm}$. 


\subsubsection{Modelo semi-empírico - com perdas}

Para a distribuição uniforme do ar, entre os orifícios presentes na caixa sopradora e considerando-se as perdas, a Figura 48 mostra a variação da seção largura da caixa sopradora, necessária para que essa distribuição uniforme do ar ocorresse.

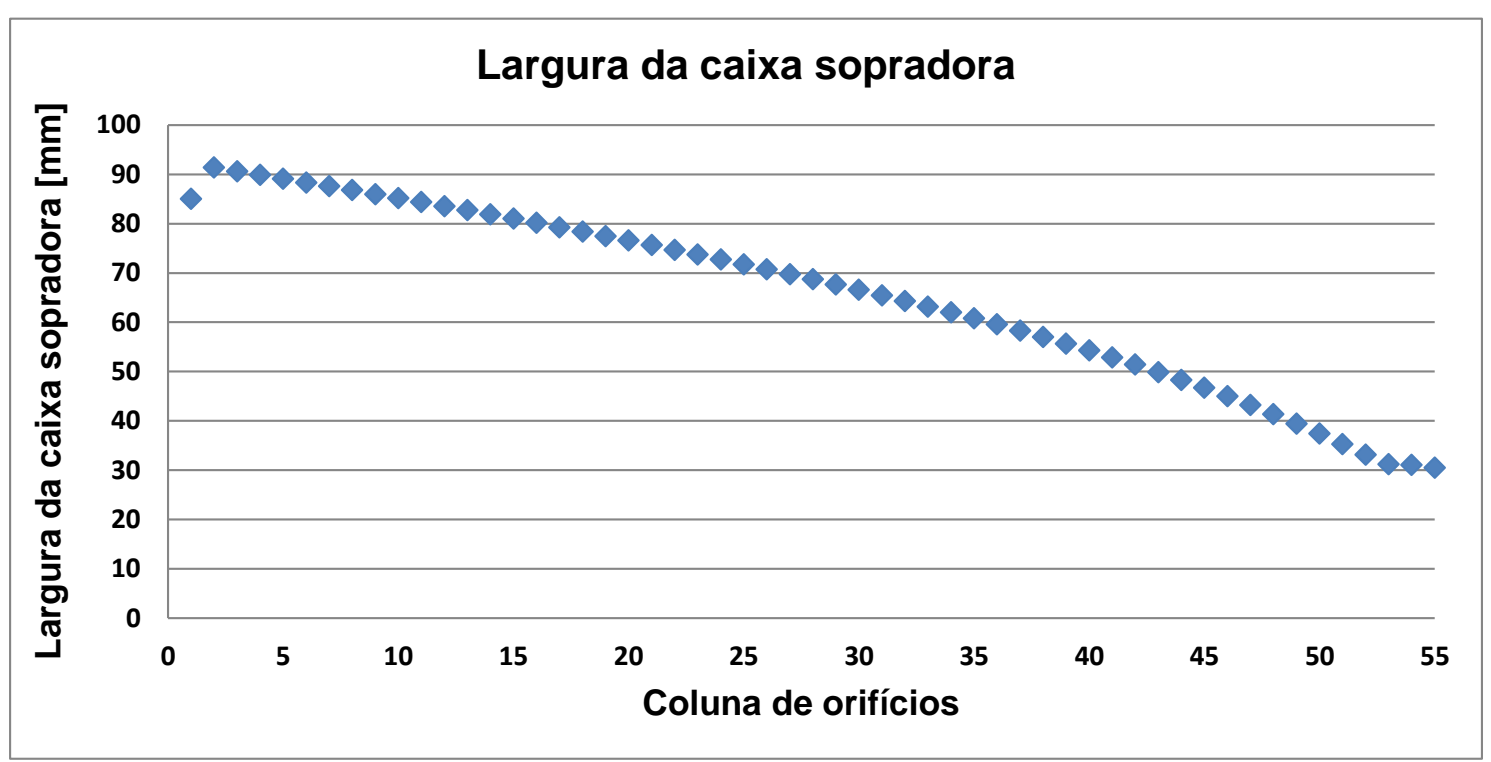

Figura 48 - Variação da largura da caixa sopradora em função das colunas de orifícios.

Neste caso a pressão da no interior da caixa sopradora variou de acordo com a Figura 49.

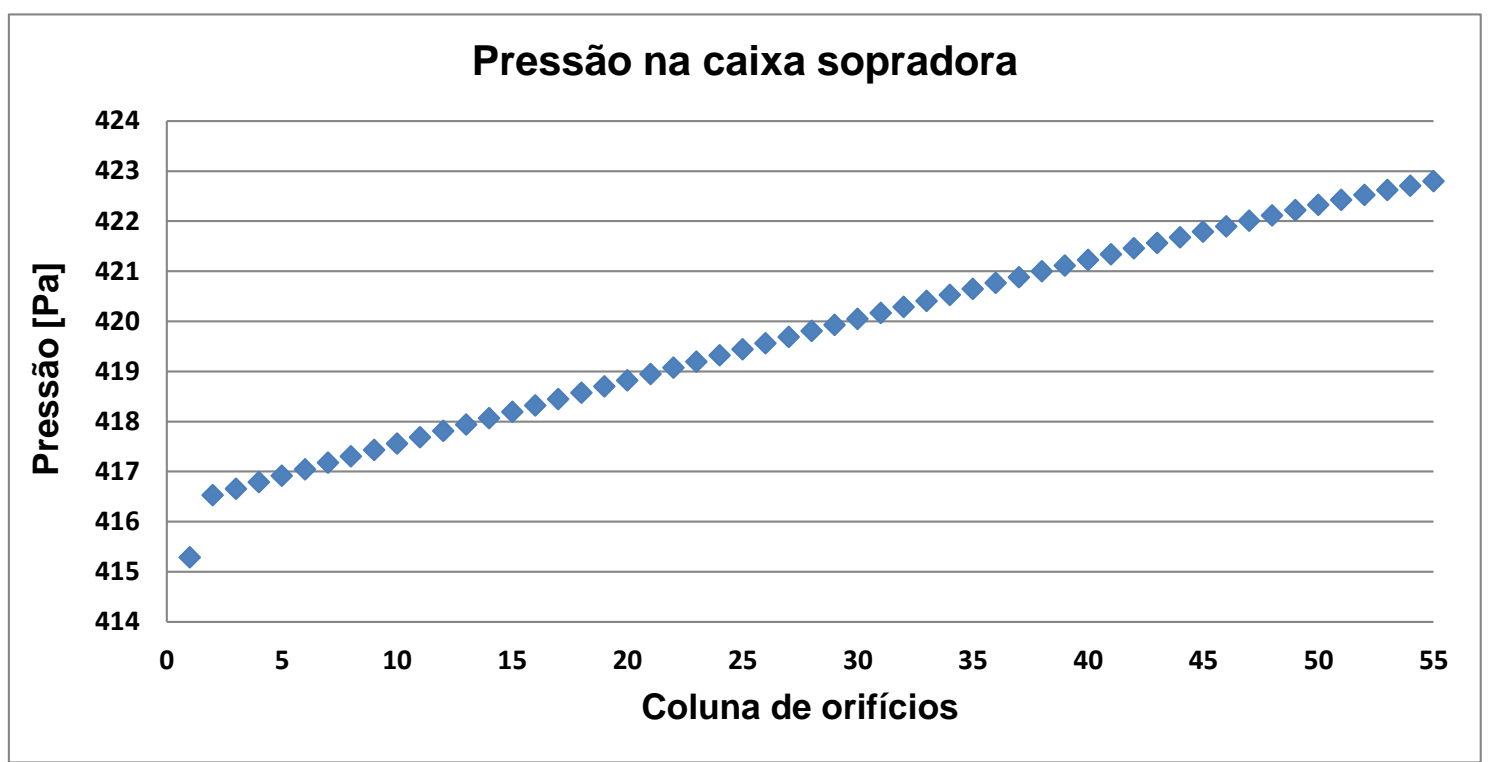

Figura 49 - Variação da pressão na caixa sopradora em função das colunas de orifícios. 
Neste caso os resultados mostrados apontam para uma redução da seção transversal de $67 \%$, partindo de $85 \mathrm{~mm}$, porém primeiramente a seção transversal aumentou para $91 \mathrm{~mm}$ para depois reduzir até $30 \mathrm{~mm}$. Já a pressão variou entre $415 \mathrm{~Pa}$ e $423 \mathrm{~Pa}$.

A redução sinalizada pelo modelo empírico foi bastante próxima da redução adotada para o cálculo numérico. O que indica também que a variação de perfil adotada representa proximidade com a redução ideal, indicada pelo modelo semi-empírico. Ressalta-se também, que as pressões encontradas na simulação numérica, com seção transversal variável, e no modelo semi-empírico com perda de energia, foram de $500 \mathrm{~Pa}$ para a simulação numérica e $423 \mathrm{~Pa}$ para o modelo semi-empírico, o que indica que os coeficientes de perda adotados podem ser considerados adequados. 


\section{CONCLUSÕES}

Este trabalho estudou o comportamento do fluxo de ar no interior de duto com múltiplas saídas, que para o presente caso está associado a caixa sopradora de máquinas desaguadoras de celulose. Para tanto foram utilizados resultados obtidos a partir de simulações numéricas, dados encontrados na literatura e informações relacionadas a ensaios experimentais.

Os resultados obtidos na revisão da literatura mostraram que a não uniformidade da velocidade média nos jatos de ar nas saídas da caixa sopradora causa perdas na eficiência energética do processo de secagem de celulose, pois a transferência de calor é influenciada pela velocidade do ar impingido contra a folha.

Para o desenvolvimento do estudo foram propostas duas alternativas de modelos geométricos distintos, para os quais foi feita a avaliação quanto a uniformidade na distribuição do ar nas saídas, caracterizada pelo balanceamento de vazões idênticas. As geometrias analisadas referiram-se ao modelo original de caixa sopradora, com seção transversal uniforme, e um novo modelo foi proposto, no qual sua seção transversal era variável.

A tentativa de se alterar a geometria da caixa sopradora mostrou-se bastante relevante, pois a variação das velocidades médias dos jatos na caixa diminui de 5,4\%, para o modelo de seção transversal uniforme, para 1,8\% no modelo de seção transversal variável.

Conforme foi obtido na revisão bibliográfica, a câmara de secagem apresenta uma assimetria de até $30 \%$ na vazão de ar destinada para as caixas sopradoras. Assim, foi definido que a vazão com valor de $30 \%$ acima do valor nominal também seria simulado numericamente.

Para a condição de vazão $30 \%$ superior a nominal a variação das velocidades medias dos jatos na caixa sopradora diminuiu de $2,6 \%$, para 0 modelo de seção transversal uniforme, para 1,4\%, no modelo de seção transversal variável. Assim, a alteração no perfil transversal da caixa 
sopradora, aumentou a uniformidade na distribuição do ar no em seus orifícios de saída, para ambas as condições analisadas.

Foi também realizada uma simulação numérica de uma caixa sopradora de testes, similar ao protótipo fabricado e testado experimentalmente. Comparando-se os resultados de diferenças de pressão entre a seção de entrada da caixa e o meio externo, os ensaios experimentais determinaram o valor de $350 \mathrm{~Pa}$, enquanto na simulação numérica esse valor foi de 345,8 Pa. A média das velocidades médias dos jatos nos ensaios experimentais foi de 30,0 $\mathrm{m} / \mathrm{s}$, enquanto nas simulações numéricas esse valor foi de $30,6 \mathrm{~m} / \mathrm{s}$. Assim, podemos assumir que os resultados obtidos através das simulações numéricas utilizados podem ser considerados, como representativos dos fenômenos físicos que acontecem no interior da caixa sopradora. Esta comparação valida os modelos e resultados da simulação numérica realizada.

Também na literatura encontrou-se referências para modelagem semi-empírica através da utilização de coeficientes de perda. Foram desenvolvidas planilhas de cálculo para a obtenção dos valores de pressão interna e seção transversal da caixa sopradora. Primeiramente foi efetuado o cálculo desprezando-se as perdas existentes, nessa condição a pressão interna na caixa foi de 400,6 Pa e a redução máxima da seção transversal foi de $98 \%$. Esta análise foi feita para verificar a operacionalidade do modelo semiempirico implementado através da planilha de cálculo.

Quando se considerou as perdas existentes, a pressão máxima no interior da caixa sopradora foi de $423 \mathrm{~Pa}$ e a redução máxima da seção transversal foi de $67 \%$. Esse resultado foi bastante similar aos resultados do modelo numérico, onde a redução da seção transversal foi reduzida de $70 \%$ e a pressão interna máxima foi de $500 \mathrm{~Pa}$. Tal similaridade comprova a adequação dos coeficientes de perda utilizados.

Assim os resultados deste trabalho confirmam a validação do processo de simulação numérica utilizado, como também o método de avaliação de escoamento em dutos de múltiplas saídas com o modelo semi-empírico estabelecido. 
Como resultado concreto deste estudo, estão apresentados modelos que possibilitam definir e simular novos parâmetros geométricos para as caixas sopradoras. Sua aplicação em máquinas desaguadoras de celulose resulta em maior eficiência energética e garantia de estabilidade na condução de folhas do processo de fabricação.

Para futuros trabalhos sugere-se estudos numéricos e experimentais sobre a transferência de calor existente no processo de impingimento do ar levando-se em consideração as variações de velocidade existentes nos diversos orifícios da caixa sopradora, conforme apresentado por este trabalho. 


\section{REFERÊNCIAS BIBLIOGRÁFICAS}

ANDRITZ Fläkt Drying Systems for Pulp \& Paper, Disponível em: <http://atl.g.andritz.com/c/spectrum/00/00/61/6177/1/1/0/41935061/flaekt_dryer.pdf>, Acessado em 01/06/2012.

AUST, R.; DURST, F.; RASZILLIER, H. Modeling a multiple-zone air impingement dryer. Chemical Engineering and Processing: Process Intensification, v. 36, n. 6, p. 469487, 1997.

BATCHELOR, G.K. An introduction to Fluid Dynamics. Cambridge University Press, 1990.

BATES, B.; ENG, P. State-of-the-art developments to save energy in coating drying. In: Proceedings of TAPPI paper conference PAPERCON. 2010.

BATHE, K. J. Finite Element Procedures, Prentice Hall; 1996.

BRACELPA, Celulose, Sisponível em <http://bracelpa.org.br/bra2/?q=node/180>, Acessado em 01/12/2013.

BUSCARIOLO, F. B. Estudo de diferentes tipos de solo em túnel de vento através de simulação numérica. Dissertação (Mestrado) - Escola Politécnica da Universidade de São Paulo. São Paulo, p. 125, 2009.

CEBECI, T.; SMITH, A. Analysis of turbulent boundary layers. 1. ed. [S.I.]: Academic Press, 1974.

CHANG, Y. B.; MORETTI, P. M. Interaction of fluttering webs with surrounding air. TAPPI journal, v. 74, n. 3, p. 231-236, 1991.

CHANG, Y. B.; CHO, H. C.; MORETTI, P. M. Edge flutter. Noise Control and Acoustics Division-Proceedings of the ASME, v. 26, p. 413-423, 1999.

CHANG, Y. B.; MORETTI, P. M. Flow-induced vibration of free edges of thin films. Journal of fluids and structures, v. 16, n. 7, p. 989-1008, 2002.

CHANG, Y. B.; MORETTI, P. M. Flow-induced vibration of free edges of thin films. Journal of fluids and structures, v. 16, n. 7, p. 989-1008, 2002.

COHEN, E.; LIGHTFOOT, E. J. Important issues in drying thin films: An industrial engineers persperctive, Ind. Coat, 1995.

D'AGOSTINI NETO, A. Simulação numérica do escoamento no tubo de sucção de turbinas hidráulicas. Dissertação (Mestrado) - Escola Politécnica da Universidade de São Paulo. São Paulo, p. 107. 2011.

PHILIPP, Paul; D'ALMEIDA, M. L. O. Celulose e papel: tecnologia de fabricação da pasta celulósica. Celulose e papel: tecnologia de fabricação da pasta celulósica, 1988.

EGOROV, Y., MENTER, F. R., LECHNER, R. COKLJAT, D. The scale-adaptative simulation method for unsteady turbulent flow predictions. Part 2: Application to Complex Flows, Flow Turbulence Combustion, v. 85, p. 139-165, 2010.

ESTADO DE SÃO PAULO, Voith desenvolve em SP nova máquina para celulose, Disponível em <http://economia.estadao.com.br/noticias/geral,voith-desenvolve-em-sp-novamaquina-para-celulose-imp-,628635,>, Acessado em 12/09/2012.

FERZIGER, P.; PERIC, M. Computational Methods for Fluid Dynamics, 2nd Edition, Springer-Verland, Germany 1999.

GREEN, M. A.; ROWLEY, C. W.; HALLER, G. Detection of lagrangian coherent structures in three-dimensional turbulence. Journal of Fluid Mechanics, v. 572, pp. 111-120, 2007. 
GUNZBURGER, M. D. Finite Element Methods for Viscous Incompressible Flows: A guide to theory, practice, and algorithms. Elsevier, 2012.

IDELCHIK, I. E., Handbook of Hydraulic Resistence. 3a edição. 2008.

LAUNDER, B. E.; SPALDING, D. B., Lectures in mathematical models of turbulence, Academic Press, London, England, 1972.

LIBBY, Paul A. An introduction to turbulence. CRC Press, 1996.

MENTER, F. Improved two-equation k-w turbulence models for aerodynamic flows, NASA Technical Memorandum 103975, California, 1992.

MENTER, F.; EGOROV, Y. The scale-adaptative simulation method for unsteady turbulent flow Predictions. Part I: Therory and Model Description, Flow Turbulence Combustion, v. 85, p. 113-138, 2010.

METSO PAPER. Pulp drying line and method for drying pulp. Patente US 6372094 B1, 2002.

METSO PAPER. Method in contact-free air-drying of a material web as well as a nozzleblow-bom and a pulp dryer that make use of the method. Patente US 5471766, 1995.

MILOSAVLJEVIC, N.; HEIKKILÄ, P. The Wall Jet -To surface heat transfer in impingement drying, 14h International Drying Symposium (IDS 2004), São Paulo, p. 1287-1297, 2004

PENTEADO, T. Z. Estudos Sobre Câmaras De Secagem de Desaguadoras de Celulose, Publicação interna, VOITH PAPER, São Paulo, 2012.

PIKULIK, I. I.; POIRIER, N. A. New developments in paper and board drying. In: Proceedings of the International Conference on the Chemical Technology of Wood, Pulp and Paper, Slovak Technical University, Bratislava. 2003. p. 56-65.

RODI, W.; SCHEUERER, G. Scrutinizing the k- $\varepsilon$ turbulence model under adverse pressure gradient conditions. Journal of Fluids Engineering, v. 108, p. X, 1986.

SCHLICHTING, H. Boundary layer theory, 7th ed., McGraw-Hill, New York,1979.

SPEZIALE, Charles G.; ABID, Ridha; ANDERSON, E. Clay. Critical evaluation of two-equation models for near-wall turbulence. AIAA journal, v. 30, n. 2, p. 324-331, 1992.

SMACNA (US). HVAC systems duct design. The Association, 4a. edição, 2006.

TENNEKES, H.; LUMLEY, J. L. A first course in turbulence. MIT Press, Cambridge, MA, 1977.

TOBALDINI NETO, L. Estudo numérico da transição laminar-turbulenta. Dissertação (Mestrado) - Escola Politécnica da Universidade de São Paulo. São Paulo, p. 153. 2006.

U.S. Energy Information Admininistration, Energy Forecast, disponível em: $<$ www.eia.gov/forecasts/ieo/industrial.cfm>, Acessado em 01/09/2013.

VERSTEEG, H. K.; MALALASEKERA, W. An introduction to computational fluid dynamics: the finite volume method, Research Studies $\operatorname{Pr}, 1995$.

VOITH PAPER Ensaios das caixas sopradoras e representações esquemáticas de máquinas de papel e desaguadoras de celulose, Publicação interna, São Paulo, 2011.

Watanabe, Y., Suzuki, S., Sugihara, M., Sueoka, Y. An experimental study of paper flutter. Journal of Fluids and Structures, v. 16, n. 4, p. 529-542, 2002.

WILCOX, D. C. Turbulence modeling for CFD, DCW Industries Inc. California, 1994. 


\section{APÊNDICE A - RESULTADOS NUMÉRICOS}

Os resultados numéricos obtidos durante as simulações, para os casos analisados são mostrados nas tabelas abaixo.

A Tabela A1,Tabela A2, Tabela A3 e Tabela A4 mostram os resultados para a velocidade média obtida em todos os orifícios para todos os casos de caixa estudados.

A coluna de orifícios 1 indica que esta é a coluna de furos mais próxima da entrada da caixa sopradora, já a coluna 55 representa a coluna mais distante da entrada. A linha de orifícios 1 indica a primeira linha vertical superior (mais alta) de orifícios, a linha 3 indica a linha central e por fim, a linha 5 indica a última linha vertical inferior (mais baixa). Por fim, assim como apresentado, foi calculada e é apresentada a média das velocidades médias para cada coluna de orifícios. 
Tabela A1 - Velocidades médias nas linhas de orifícios para a caixas sopradora de seção uniforme e vazão nominal.

\begin{tabular}{|c|c|c|c|c|c|c|}
\hline Colunas analisadas & \multicolumn{6}{|c|}{ Velocidade nas linhas analisadas [m/s] } \\
\hline Coluna número & Linha 1 & Linha 2 & Linha 3 & Linha 4 & Linha 5 & Média \\
\hline 1 & 31,750 & 31,550 & 31,584 & 31,359 & 31,680 & 31,585 \\
\hline 2 & 31,523 & 31,675 & 31,424 & 31,719 & 31,418 & 31,552 \\
\hline 3 & 31,701 & 31,605 & 31,644 & 31,661 & 31,761 & 31,674 \\
\hline 4 & 31,866 & 31,768 & 31,423 & 31,831 & 31,730 & 31,724 \\
\hline 5 & 31,669 & 31,650 & 31,853 & 31,812 & 31,863 & 31,769 \\
\hline 6 & 31,873 & 31,747 & 31,837 & 31,656 & 31,802 & 31,783 \\
\hline 7 & 31,849 & 31,664 & 31,998 & 31,813 & 31,863 & 31,837 \\
\hline 8 & 31,706 & 31,819 & 32,066 & 31,858 & 32,060 & 31,902 \\
\hline 9 & 32,011 & 31,715 & 31,904 & 31,732 & 32,066 & 31,886 \\
\hline 10 & 31,987 & 31,720 & 31,767 & 31,941 & 32,169 & 31,917 \\
\hline 11 & 32,251 & 31,856 & 32,178 & 31,831 & 32,161 & 32,055 \\
\hline 12 & 32,092 & 31,957 & 32,059 & 32,070 & 32,103 & 32,056 \\
\hline 13 & 32,170 & 31,863 & 32,111 & 32,043 & 32,216 & 32,081 \\
\hline 14 & 32,106 & 31,880 & 32,097 & 31,840 & 32,068 & 31,998 \\
\hline 15 & 32,384 & 32,087 & 32,197 & 32,041 & 32,356 & 32,213 \\
\hline 16 & 32,290 & 32,050 & 32,115 & 32,284 & 32,236 & 32,195 \\
\hline 17 & 31,992 & 32,156 & 32,056 & 32,140 & 32,715 & 32,212 \\
\hline 18 & 32,343 & 32,167 & 32,364 & 32,379 & 32,531 & 32,357 \\
\hline 19 & 32,431 & 32,228 & 32,238 & 32,476 & 32,501 & 32,375 \\
\hline 20 & 32,402 & 32,178 & 32,453 & 32,434 & 32,811 & 32,456 \\
\hline 21 & 32,415 & 32,191 & 32,567 & 32,272 & 32,732 & 32,435 \\
\hline 22 & 32,540 & 32,160 & 32,509 & 32,298 & 32,420 & 32,385 \\
\hline 23 & 32,609 & 32,166 & 32,383 & 32,327 & 32,618 & 32,421 \\
\hline 24 & 32,622 & 32,436 & 32,692 & 32,510 & 32,802 & 32,612 \\
\hline 25 & 32,874 & 32,394 & 32,823 & 32,506 & 32,662 & 32,652 \\
\hline 26 & 32,720 & 32,498 & 32,426 & 32,556 & 32,973 & 32,635 \\
\hline 27 & 32,772 & 32,500 & 32,818 & 32,768 & 32,765 & 32,725 \\
\hline 28 & 32,553 & 32,626 & 32,731 & 32,926 & 33,000 & 32,767 \\
\hline 29 & 32,648 & 33,087 & 33,164 & 32,828 & 33,092 & 32,964 \\
\hline 30 & 32,995 & 32,942 & 32,994 & 32,686 & 33,014 & 32,926 \\
\hline 31 & 32,825 & 32,933 & 33,074 & 32,834 & 32,850 & 32,903 \\
\hline 32 & 32,943 & 33,157 & 33,127 & 32,765 & 33,193 & 33,037 \\
\hline 33 & 33,179 & 32,806 & 33,183 & 32,898 & 33,075 & 33,028 \\
\hline 34 & 33,177 & 33,122 & 32,896 & 32,922 & 33,239 & 33,071 \\
\hline 35 & 33,344 & 33,001 & 33,231 & 33,205 & 33,596 & 33,275 \\
\hline 36 & 33,148 & 33,025 & 33,391 & 33,024 & 33,358 & 33,189 \\
\hline 37 & 33,442 & 33,205 & 33,393 & 33,464 & 33,542 & 33,409 \\
\hline 38 & 33,638 & 33,173 & 33,312 & 33,545 & 33,642 & 33,462 \\
\hline 39 & 33,839 & 33,058 & 33,534 & 33,605 & 34,021 & 33,611 \\
\hline 40 & 33,236 & 33,253 & 33,691 & 33,316 & 33,840 & 33,467 \\
\hline 41 & 33,430 & 33,503 & 33,603 & 33,397 & 33,663 & 33,519 \\
\hline 42 & 33,432 & 33,541 & 33,697 & 33,518 & 34,158 & 33,669 \\
\hline 43 & 33,471 & 33,731 & 33,516 & 33,503 & 34,108 & 33,666 \\
\hline 44 & 34,439 & 33,476 & 33,780 & 33,866 & 34,226 & 33,957 \\
\hline 45 & 33,719 & 33,858 & 33,942 & 33,900 & 33,992 & 33,882 \\
\hline 46 & 33,908 & 33,641 & 34,064 & 33,993 & 34,164 & 33,954 \\
\hline 47 & 34,201 & 33,802 & 34,138 & 34,055 & 34,202 & 34,080 \\
\hline 48 & 33,961 & 33,951 & 34,004 & 34,058 & 34,149 & 34,025 \\
\hline 49 & 34,423 & 34,075 & 34,360 & 34,255 & 34,329 & 34,289 \\
\hline 50 & 34,024 & 34,220 & 34,268 & 34,019 & 34,615 & 34,229 \\
\hline 51 & 34,242 & 34,289 & 34,432 & 34,146 & 34,720 & 34,36 \\
\hline 52 & 34,626 & 34,316 & 34,727 & 34,406 & 34,218 & 34,459 \\
\hline 53 & 34,312 & 34,555 & 34,396 & 34,209 & 34,711 & 34,437 \\
\hline 54 & 34,597 & 34,563 & 34,681 & 34,754 & 34,286 & 34,576 \\
\hline 55 & 34,499 & 34,279 & 34,636 & 35,111 & 34,332 & 34,571 \\
\hline
\end{tabular}


Tabela A2 - Velocidades médias nas linhas de orifícios para a caixas sopradora de seção transversal uniforme e vazão $30 \%$ superior a nominal.

\section{Colunas analisadas Velocidade nas linhas analisadas [m/s]}

\begin{tabular}{|c|c|c|c|c|c|c|}
\hline Coluna número & Linha 1 & Linha 2 & Linha 3 & Linha 4 & Linha 5 & Média \\
\hline 1 & 42,088 & 42,044 & 42,688 & 42,155 & 42,121 & 42,219 \\
\hline 2 & 42,155 & 42,566 & 42,110 & 42,133 & 42,233 & 42,239 \\
\hline 3 & 42,388 & 41,999 & 42,066 & 42,421 & 42,510 & 42,277 \\
\hline 4 & 42,133 & 42,410 & 42,077 & 42,577 & 42,410 & 42,321 \\
\hline 5 & 42,833 & 42,377 & 42,310 & 42,388 & 42,544 & 42,490 \\
\hline 6 & 42,577 & 42,488 & 42,277 & 42,533 & 42,777 & 42,530 \\
\hline 7 & 43,088 & 42,399 & 42,377 & 42,288 & 43,177 & 42,666 \\
\hline 8 & 42,533 & 42,444 & 42,166 & 42,688 & 42,477 & 42,461 \\
\hline 9 & 42,810 & 42,555 & 42,566 & 42,499 & 42,610 & 42,608 \\
\hline 10 & 42,321 & 42,466 & 42,933 & 42,244 & 42,299 & 42,453 \\
\hline 11 & 42,621 & 42,499 & 42,544 & 42,688 & 42,699 & 42,610 \\
\hline 12 & 42,733 & 42,310 & 42,333 & 42,255 & 42,699 & 42,466 \\
\hline 13 & 42,599 & 42,688 & 42,144 & 42,466 & 43,710 & 42,721 \\
\hline 14 & 42,699 & 42,699 & 42,555 & 42,566 & 42,488 & 42,601 \\
\hline 15 & 42,388 & 42,355 & 42,455 & 42,321 & 42,888 & 42,481 \\
\hline 16 & 43,321 & 42,744 & 42,299 & 42,633 & 43,310 & 42,861 \\
\hline 17 & 42,577 & 42,388 & 42,255 & 42,721 & 42,488 & 42,486 \\
\hline 18 & 42,966 & 42,555 & 42,566 & 42,633 & 42,999 & 42,744 \\
\hline 19 & 43,299 & 42,521 & 42,333 & 42,366 & 43,155 & 42,735 \\
\hline 20 & 42,910 & 42,321 & 42,466 & 42,499 & 42,766 & 42,593 \\
\hline 21 & 42,733 & 42,477 & 42,388 & 42,599 & 42,744 & 42,588 \\
\hline 22 & 43,310 & 42,544 & 42,488 & 42,521 & 43,299 & 42,833 \\
\hline 23 & 42,988 & 42,466 & 42,844 & 42,388 & 42,944 & 42,726 \\
\hline 24 & 43,110 & 42,733 & 42,744 & 42,655 & 42,966 & 42,841 \\
\hline 25 & 43,077 & 42,677 & 42,421 & 42,433 & 42,966 & 42,715 \\
\hline 26 & 42,466 & 42,721 & 42,766 & 42,899 & 42,933 & 42,757 \\
\hline 27 & 43,355 & 42,677 & 42,733 & 42,755 & 43,544 & 43,013 \\
\hline 28 & 42,877 & 42,855 & 42,799 & 42,755 & 43,033 & 42,864 \\
\hline 29 & 42,899 & 42,721 & 42,755 & 42,877 & 43,110 & 42,873 \\
\hline 30 & 43,466 & 42,610 & 42,755 & 42,977 & 43,121 & 42,986 \\
\hline 31 & 43,166 & 42,699 & 42,721 & 43,144 & 43,299 & 43,006 \\
\hline 32 & 43,410 & 42,655 & 42,644 & 43,199 & 43,444 & 43,070 \\
\hline 33 & 42,777 & 42,844 & 42,833 & 42,855 & 43,277 & 42,917 \\
\hline 34 & 43,721 & 42,699 & 42,899 & 42,888 & 43,533 & 43,148 \\
\hline 35 & 42,810 & 42,877 & 42,966 & 43,099 & 43,221 & 42,995 \\
\hline 36 & 43,521 & 43,110 & 42,910 & 43,221 & 43,210 & 43,195 \\
\hline 37 & 43,399 & 43,033 & 42,766 & 43,255 & 43,466 & 43,184 \\
\hline 38 & 43,266 & 43,033 & 42,721 & 42,988 & 43,255 & 43,053 \\
\hline 39 & 43,310 & 43,221 & 42,788 & 43,621 & 43,010 & 43,190 \\
\hline 40 & 43,110 & 43,121 & 42,888 & 43,144 & 43,188 & 43,090 \\
\hline 41 & 43,244 & 43,221 & 43,099 & 43,133 & 43,599 & 43,259 \\
\hline 42 & 43,277 & 43,188 & 42,921 & 43,355 & 43,177 & 43,184 \\
\hline 43 & 43,145 & 43,488 & 43,033 & 43,366 & 43,210 & 43,248 \\
\hline 44 & 44,388 & 43,366 & 43,166 & 43,321 & 43,922 & 43,633 \\
\hline 45 & 43,370 & 43,766 & 43,310 & 43,377 & 43,344 & 43,433 \\
\hline 46 & 43,444 & 43,821 & 43,233 & 43,721 & 43,835 & 43,611 \\
\hline 47 & 43,744 & 43,199 & 43,277 & 43,533 & 44,106 & 43,572 \\
\hline 48 & 44,133 & 43,677 & 43,533 & 43,288 & 43,877 & 43,701 \\
\hline 49 & 44,099 & 43,518 & 43,299 & 43,908 & 44,033 & 43,77 \\
\hline 50 & 43,902 & 43,177 & 43,244 & 43,757 & 43,562 & 43,528 \\
\hline 51 & 43,510 & 44,126 & 43,355 & 43,982 & 44,574 & 43,910 \\
\hline 52 & 44,399 & 43,421 & 44,733 & 44,265 & 43,266 & 44,017 \\
\hline 53 & 44,021 & 44,561 & 44,363 & 43,861 & 44,420 & 44,245 \\
\hline 54 & 43,621 & 44,336 & 43,788 & 44,645 & 43,299 & 43,938 \\
\hline 55 & 45,042 & 44,244 & 44,503 & 45,179 & 45,566 & 44,9 \\
\hline
\end{tabular}


Tabela A3 - Velocidades médias nas linhas de orifícios para a caixas sopradora de seção transversal variável e vazão nominal.

Colunas analisadas

\begin{tabular}{|c|c|c|c|c|c|c|}
\hline Colunas analisadas & \multicolumn{6}{|c|}{ Velocidade nas linhas analisadas [m/s] } \\
\hline Coluna número & Linha 1 & Linha 2 & Linha 3 & Linha 4 & Linha 5 & Média \\
\hline 1 & 32,310 & 32,243 & 32,155 & 32,127 & 32,292 & 32,225 \\
\hline 2 & 32,102 & 32,131 & 32,062 & 32,414 & 32,127 & 32,167 \\
\hline 3 & 32,562 & 32,415 & 32,257 & 32,071 & 32,570 & 32,375 \\
\hline 4 & 32,569 & 32,428 & 32,335 & 32,342 & 32,559 & 32,447 \\
\hline 5 & 32,439 & 32,223 & 32,335 & 32,132 & 32,573 & 32,340 \\
\hline 6 & 32,622 & 32,235 & 32,248 & 32,296 & 32,647 & 32,410 \\
\hline 7 & 32,594 & 32,412 & 32,421 & 32,314 & 32,575 & 32,463 \\
\hline 8 & 32,398 & 32,430 & 32,578 & 32,404 & 32,558 & 32,474 \\
\hline 9 & 32,655 & 32,225 & 32,420 & 32,424 & 32,662 & 32,477 \\
\hline 10 & 32,553 & 32,363 & 32,261 & 32,168 & 32,719 & 32,413 \\
\hline 11 & 32,541 & 32,225 & 32,330 & 32,232 & 32,871 & 32,440 \\
\hline 12 & 32,674 & 32,404 & 32,379 & 32,228 & 32,627 & 32,462 \\
\hline 13 & 32,674 & 32,562 & 32,321 & 32,547 & 32,820 & 32,585 \\
\hline 14 & 32,666 & 32,294 & 32,517 & 32,408 & 32,689 & 32,515 \\
\hline 15 & 32,483 & 32,245 & 32,485 & 32,406 & 32,492 & 32,422 \\
\hline 16 & 32,517 & 32,285 & 32,441 & 32,657 & 32,755 & 32,531 \\
\hline 17 & 32,765 & 32,271 & 32,259 & 32,434 & 32,785 & 32,503 \\
\hline 18 & 32,544 & 32,444 & 32,352 & 32,586 & 32,553 & 32,496 \\
\hline 19 & 32,685 & 32,327 & 32,398 & 32,622 & 32,940 & 32,594 \\
\hline 20 & 32,679 & 32,617 & 32,585 & 32,254 & 32,690 & 32,565 \\
\hline 21 & 32,736 & 32,356 & 32,612 & 32,485 & 32,844 & 32,607 \\
\hline 22 & 32,849 & 32,685 & 32,421 & 32,323 & 32,940 & 32,644 \\
\hline 23 & 32,651 & 32,396 & 32,565 & 32,670 & 32,659 & 32,588 \\
\hline 24 & 32,656 & 32,484 & 32,681 & 32,625 & 32,662 & 32,622 \\
\hline 25 & 32,776 & 32,590 & 32,694 & 32,234 & 32,801 & 32,619 \\
\hline 26 & 32,463 & 32,743 & 32,637 & 32,679 & 32,728 & 32,650 \\
\hline 27 & 32,737 & 32,631 & 32,709 & 32,401 & 32,996 & 32,695 \\
\hline 28 & 32,726 & 32,743 & 32,871 & 32,801 & 32,942 & 32,816 \\
\hline 29 & 32,892 & 32,644 & 32,785 & 32,619 & 32,992 & 32,786 \\
\hline 30 & 32,935 & 32,789 & 32,864 & 32,764 & 33,195 & 32,909 \\
\hline 31 & 32,728 & 32,665 & 32,469 & 32,676 & 32,745 & 32,657 \\
\hline 32 & 32,757 & 32,678 & 32,776 & 32,734 & 32,875 & 32,764 \\
\hline 33 & 32,818 & 32,798 & 32,843 & 32,681 & 33,053 & 32,838 \\
\hline 34 & 32,698 & 32,870 & 32,689 & 32,894 & 32,761 & 32,782 \\
\hline 35 & 32,844 & 32,879 & 32,911 & 32,666 & 33,161 & 32,892 \\
\hline 36 & 32,685 & 32,801 & 33,095 & 32,785 & 32,930 & 32,859 \\
\hline 37 & 32,728 & 32,654 & 32,889 & 32,601 & 33,135 & 32,801 \\
\hline 38 & 32,792 & 32,757 & 32,825 & 32,964 & 32,809 & 32,829 \\
\hline 39 & 32,864 & 32,865 & 32,950 & 32,775 & 33,127 & 32,916 \\
\hline 40 & 32,859 & 32,770 & 33,012 & 32,848 & 33,243 & 32,946 \\
\hline 41 & 32,899 & 32,838 & 32,981 & 33,113 & 33,237 & 33,014 \\
\hline 42 & 32,796 & 32,821 & 32,978 & 33,095 & 32,950 & 32,928 \\
\hline 43 & 32,739 & 32,788 & 33,050 & 33,057 & 32,838 & 32,894 \\
\hline 44 & 32,823 & 32,916 & 33,013 & 33,163 & 33,240 & 33,031 \\
\hline 45 & 33,100 & 32,992 & 33,010 & 33,198 & 33,099 & 33,080 \\
\hline 46 & 32,893 & 32,956 & 32,873 & 33,194 & 33,202 & 33,024 \\
\hline 47 & 33,247 & 33,304 & 33,072 & 33,135 & 33,398 & 33,231 \\
\hline 48 & 33,072 & 32,938 & 33,112 & 32,778 & 33,136 & 33,007 \\
\hline 49 & 33,044 & 32,865 & 33,110 & 32,858 & 33,309 & 33,037 \\
\hline 50 & 33,069 & 32,966 & 33,177 & 33,071 & 33,302 & 33,117 \\
\hline 51 & 33,200 & 33,236 & 33,348 & 33,263 & 33,192 & 33,248 \\
\hline 52 & 33,219 & 32,904 & 33,664 & 32,904 & 33,084 & 33,155 \\
\hline 53 & 33,287 & 32,978 & 33,119 & 32,951 & 33,210 & 33,109 \\
\hline 54 & 33,087 & 32,955 & 32,956 & 32,965 & 33,526 & 33,098 \\
\hline 55 & 33,059 & 33,518 & 33,184 & 33,446 & 33,234 & 33,288 \\
\hline
\end{tabular}


Tabela A4 - Velocidades médias nas linhas de orifícios para a caixas sopradora de seção transversal variável e vazão $30 \%$ superior a nominal.

Colunas analisadas Velocidade nas linhas analisadas [m/s]

Coluna número Linha 1 Linha 2 Linha 3 Linha 4 Linha 5 Média

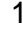

2

3

4

5

6

7

8

9

10

11

12

13

14

15

16

17

18

19

20

21

22

23

24

25

26

27

28

29

30

31

32

33

34

35

36

37

38

39

40

41

42

43

44

45

46

47

48

49

50

51

52

53

54

55

$\begin{array}{lllllll}41,917 & 41,964 & 41,893 & 41,802 & 42,021 & 41,919\end{array}$

$\begin{array}{lllllll}41,626 & 41,822 & 41,865 & 42,347 & 41,658 & 41,863\end{array}$

$\begin{array}{llllllll}42,357 & 42,283 & 42,102 & 41,765 & 42,324 & 42,166\end{array}$

$\begin{array}{llllllll}42,489 & 42,139 & 42,149 & 42,132 & 42,357 & 42,253\end{array}$

$\begin{array}{llllllll}42,545 & 41,884 & 42,170 & 41,841 & 42,654 & 42,219\end{array}$

$\begin{array}{llllllll}42,555 & 41,867 & 41,963 & 42,011 & 42,653 & 42,210\end{array}$

$\begin{array}{llllllll}42,813 & 42,289 & 42,228 & 42,009 & 42,650 & 42,398\end{array}$

$\begin{array}{llllllll}42,405 & 42,182 & 42,519 & 42,086 & 42,410 & 42,320\end{array}$

$\begin{array}{lllllllll}42,460 & 41,951 & 42,289 & 42,236 & 42,334 & 42,254\end{array}$

$\begin{array}{llllllll}42,429 & 42,347 & 42,013 & 41,798 & 42,590 & 42,235\end{array}$

\begin{tabular}{lll|l|l|l|l}
42,312 & 42,102 & 42,164 & 42,011 & 42,840 & 42,286
\end{tabular}

\begin{tabular}{lll|l|l|l|l}
42,960 & 42,234 & 42,159 & 42,105 & 42,507 & 42,393
\end{tabular}

$\begin{array}{llllllll}42,795 & 42,270 & 42,029 & 42,385 & 42,550 & 42,406\end{array}$

\begin{tabular}{lll|l|l|l|l}
42,576 & 42,073 & 42,324 & 42,201 & 42,603 & 42,355
\end{tabular}

\begin{tabular}{|l|l|l|l|l|l|}
42,460 & 41,941 & 42,304 & 42,205 & 42,368 & 42,256
\end{tabular}

\begin{tabular}{|l|l|l|l|l|l|l}
42,476 & 41,975 & 42,185 & 42,484 & 42,510 & 42,326
\end{tabular}

\begin{tabular}{|l|l|l|l|l|l}
42,822 & 42,069 & 42,054 & 42,165 & 43,155 & 42,453
\end{tabular}

\begin{tabular}{lll|l|l|l|l}
42,443 & 42,276 & 42,062 & 43,096 & 42,266 & 42,429
\end{tabular}

$\begin{array}{llllllll}42,437 & 42,062 & 42,122 & 42,348 & 42,856 & 42,365\end{array}$

\begin{tabular}{lll|l|l|l|l}
42,422 & 42,360 & 42,376 & 41,852 & 42,669 & 42,336
\end{tabular}

$\begin{array}{lllllllll}42,569 & 42,089 & 42,451 & 42,355 & 42,929 & 42,479\end{array}$

\begin{tabular}{|l|l|l|l|l|l}
42,746 & 42,412 & 42,109 & 41,996 & 43,101 & 42,473
\end{tabular}

$\begin{array}{lllllllll}42,521 & 41,968 & 42,357 & 42,414 & 42,430 & 42,338\end{array}$

\begin{tabular}{lll|l|l|l|l}
42,545 & 42,100 & 42,487 & 42,352 & 42,339 & 42,365
\end{tabular}

\begin{tabular}{lll|l|l|l|l}
42,618 & 42,437 & 42,485 & 41,797 & 42,913 & 42,450 \\
\hline
\end{tabular}

\begin{tabular}{|l|l|l|l|l|l|l}
42,081 & 42,658 & 42,451 & 42,731 & 42,696 & 42,523
\end{tabular}

$\begin{array}{llllllll}42,815 & 42,403 & 42,739 & 42,184 & 43,111 & 42,650\end{array}$

$\begin{array}{llllllll}42,766 & 42,553 & 42,635 & 42,723 & 42,767 & 42,689\end{array}$

\begin{tabular}{l|l|l|l|l|l}
42,695 & 42,366 & 42,537 & 42,435 & 43,122 & 42,631
\end{tabular}

\begin{tabular}{|l|l|l|l|l|l|}
42,941 & 42,580 & 42,739 & 42,609 & 43,225 & 42,819
\end{tabular}

\begin{tabular}{lll|l|l|l|l}
42,861 & 42,371 & 42,305 & 42,458 & 42,755 & 42,550
\end{tabular}

$\begin{array}{llllllll}42,691 & 42,370 & 42,848 & 42,392 & 42,585 & 42,577\end{array}$

$\begin{array}{llllllll}43,122 & 42,679 & 42,686 & 42,373 & 43,182 & 42,808\end{array}$

\begin{tabular}{lll|l|l|l|l}
42,654 & 42,798 & 42,420 & 42,785 & 42,685 & 42,668
\end{tabular}

$\begin{array}{llllllll}43,305 & 42,770 & 42,969 & 42,311 & 43,290 & 42,929\end{array}$

\begin{tabular}{lll|l|l|l|l}
42,622 & 42,487 & 42,873 & 42,444 & 42,649 & 42,615 \\
\hline
\end{tabular}

\begin{tabular}{llllllll}
43,041 & 42,397 & 42,666 & 42,307 & 43,566 & 42,795 \\
\hline
\end{tabular}

\begin{tabular}{lll|l|l|l|l}
42,996 & 42,462 & 42,587 & 42,738 & 42,943 & 42,745
\end{tabular}

\begin{tabular}{l|l|l|l|l|l|l}
42,975 & 42,901 & 42,735 & 42,493 & 43,519 & 42,925 \\
\hline
\end{tabular}

$\begin{array}{llllllll}42,925 & 42,432 & 42,792 & 42,609 & 43,404 & 42,833\end{array}$

\begin{tabular}{l|l|l|l|l|l}
42,610 & 42,673 & 42,756 & 42,945 & 43,206 & 42,838
\end{tabular}

$\begin{array}{lllllllll}42,575 & 42,683 & 42,693 & 42,911 & 42,902 & 42,753\end{array}$

\begin{tabular}{lll|l|l|l|l|l}
42,407 & 42,485 & 42,875 & 42,774 & 42,644 & 42,637
\end{tabular}

$\begin{array}{llllllll}42,416 & 42,538 & 42,629 & 43,029 & 43,070 & 42,736\end{array}$

$\begin{array}{llllllll}42,826 & 42,652 & 42,747 & 42,859 & 42,733 & 42,763\end{array}$

\begin{tabular}{lll|l|l|l|l}
42,806 & 42,529 & 42,532 & 42,891 & 42,871 & 42,726
\end{tabular}

$\begin{array}{llllllll}42,190 & 42,843 & 42,769 & 42,942 & 43,355 & 43,020\end{array}$

\begin{tabular}{lll|l|l|l|l}
42,944 & 42,780 & 43,039 & 42,601 & 42,855 & 42,844
\end{tabular}

$\begin{array}{llllllll}42,882 & 42,296 & 42,758 & 42,349 & 43,080 & 42,673\end{array}$

\begin{tabular}{lll|l|l|l|l}
43,188 & 42,413 & 43,030 & 42,875 & 42,980 & 42,897
\end{tabular}

\begin{tabular}{lll|l|l|l|l}
43,248 & 42,685 & 43,031 & 43,071 & 43,052 & 43,018
\end{tabular}

$\begin{array}{llllllll}43,384 & 42,603 & 43,532 & 42,538 & 42,873 & 42,986\end{array}$

\begin{tabular}{l|l|l|l|l|l}
43,339 & 42,623 & 43,030 & 42,773 & 43,265 & 43,006
\end{tabular}

\begin{tabular}{l|l|l|l|l|l}
42,459 & 42,398 & 42,685 & 42,634 & 43,699 & 42,775
\end{tabular}

$\begin{array}{llllllll}43,101 & 42,998 & 43,129 & 43,770 & 43,142 & 43,228\end{array}$ 


\section{APÊNDICE B - RESULTADOS MODELO SEMI-EMPÍRICO}

Os parâmetros utilizados na planilha de cálculo para a caixa sopradora, através da análise semi-empírica, são mostrados na Tabela B1 e na Tabela B3. Estes parâmetros foram considerados constantes durante todo o cálculo.

Os resultados obtidos são mostrados na Tabela B2 e na Tabela B4. Tanto os parâmetros considerados quanto os resultados obtidos estão divididos em duas situações distintas, considerando-se ou não as perdas de energia existentes no duto devido às suas singularidades na região dos orifícios destes dutos.

Tabela B1 - Parâmetros de entrada para o modelo semi-empírico sem perdas de energia.

\begin{tabular}{lcc}
\hline \multicolumn{1}{c}{ Parâmetros } & Valores & Unidades \\
\hline Linhas de orifícios & 5 & - \\
$\begin{array}{l}\text { Distância entre colunas } \\
\text { de orifícios }\end{array}$ & 0,08 & $\mathrm{~m}$ \\
$\begin{array}{l}\text { Colunas de orifícios } \\
\text { Diâmetro dos orifícios }\end{array}$ & 0,004 & - \\
$\begin{array}{l}\text { Massa especifica do ar } \\
\text { Vazão mássica de ar }\end{array}$ & 0,75 & $\mathrm{mg} / \mathrm{m}^{3}$ \\
$\begin{array}{l}\text { Altura da caixa } \\
\text { sopradora }\end{array}$ & 0,3 & $\mathrm{~kg} / \mathrm{s}$ \\
$\begin{array}{l}\text { Largura inicial da caixa } \\
\text { sopradora }\end{array}$ & 0,085 & $\mathrm{~m}$ \\
$\begin{array}{l}\text { Fator de perda pela } \\
\text { saída no orifício }\end{array}$ & 0 & - \\
$\begin{array}{l}\text { Fator de perda pela } \\
\text { expansão após o } \\
\text { orifício }\end{array}$ & 0 & - \\
$\begin{array}{l}\text { Velocidade do jato de ar } \\
\text { nos orifícios }\end{array}$ & 32,99 & $\mathrm{~m} / \mathrm{s}$ \\
\hline
\end{tabular}


Tabela B2 - Resultados de pressão interna, velocidade interna e perfil para a caixa sopradora para o modelo semi-empírico sem perdas de energia.

\begin{tabular}{|c|c|c|c|c|c|}
\hline $\begin{array}{c}\text { orifício k } \\
-\end{array}$ & $\begin{array}{c}\text { Largura da caixa } \\
\text { sopradora antes } \\
\text { do orifício k } \\
m \\
\end{array}$ & $\begin{array}{c}\text { Área da seção transversal } \\
\text { da caixa sopradora antes } \\
\text { do furo } \mathrm{k} \\
\mathrm{m}^{2} \\
\end{array}$ & $\begin{array}{c}\text { vazão mássica } \\
\text { antes do furo k } \\
\mathrm{kg} / \mathrm{s}\end{array}$ & $\begin{array}{c}\text { Velocidade no interior } \\
\text { da caixa sopradora } \\
\text { antes do orifício k } \\
\mathrm{m} / \mathrm{s}\end{array}$ & $\begin{array}{c}\text { Pressão na caixa } \\
\text { sopradora antes do } \\
\text { orifício } \mathrm{k} \\
\mathrm{Pa}\end{array}$ \\
\hline 1 & 0,085 & 0,0255 & 0,0855 & 4,471 & 400,6 \\
\hline 2 & 0,083 & 0,0250 & 0,0839 & 4,471 & 400,6 \\
\hline 3 & 0,082 & 0,0246 & 0,0824 & 4,471 & 400,6 \\
\hline 4 & 0,080 & 0,0241 & 0,0808 & 4,471 & 400,6 \\
\hline 5 & 0,079 & 0,0236 & 0,0793 & 4,471 & 400,6 \\
\hline 6 & 0,077 & 0,0232 & 0,0777 & 4,471 & 400,6 \\
\hline 7 & 0,076 & 0,0227 & 0,0762 & 4,471 & 400,6 \\
\hline 8 & 0,074 & 0,0223 & 0,0746 & 4,471 & 400,6 \\
\hline 9 & 0,073 & 0,0218 & 0,0731 & 4,471 & 400,6 \\
\hline 10 & 0,071 & 0,0213 & 0,0715 & 4,471 & 400,6 \\
\hline 11 & 0,070 & 0,0209 & 0,0700 & 4,471 & 400,6 \\
\hline 12 & 0,068 & 0,0204 & 0,0684 & 4,471 & 400,6 \\
\hline 13 & 0,066 & 0,0199 & 0,0668 & 4,471 & 400,6 \\
\hline 14 & 0,065 & 0,0195 & 0,0653 & 4,471 & 400,6 \\
\hline 15 & 0,063 & 0,0190 & 0,0637 & 4,471 & 400,6 \\
\hline 16 & 0,062 & 0,0185 & 0,0622 & 4,471 & 400,6 \\
\hline 17 & 0,060 & 0,0181 & 0,0606 & 4,471 & 400,6 \\
\hline 18 & 0,059 & 0,0176 & 0,0591 & 4,471 & 400,6 \\
\hline 19 & 0,057 & 0,0172 & 0,0575 & 4,471 & 400,6 \\
\hline 20 & 0,056 & 0,0167 & 0,0560 & 4,471 & 400,6 \\
\hline 21 & 0,054 & 0,0162 & 0,0544 & 4,471 & 400,6 \\
\hline 22 & 0,053 & 0,0158 & 0,0529 & 4,471 & 400,6 \\
\hline 23 & 0,051 & 0,0153 & 0,0513 & 4,471 & 400,6 \\
\hline 24 & 0,049 & 0,0148 & 0,0497 & 4,471 & 400,6 \\
\hline 25 & 0,048 & 0,0144 & 0,0482 & 4,471 & 400,6 \\
\hline 26 & 0,046 & 0,0139 & 0,0466 & 4,471 & 400,6 \\
\hline 27 & 0,045 & 0,0134 & 0,0451 & 4,471 & 400,6 \\
\hline 28 & 0,043 & 0,0130 & 0,0435 & 4,471 & 400,6 \\
\hline 29 & 0,042 & 0,0125 & 0,0420 & 4,471 & 400,6 \\
\hline 30 & 0,040 & 0,0121 & 0,0404 & 4,471 & 400,6 \\
\hline 31 & 0,039 & 0,0116 & 0,0389 & 4,471 & 400,6 \\
\hline 32 & 0,037 & 0,0111 & 0,0373 & 4,471 & 400,6 \\
\hline 33 & 0,036 & 0,0107 & 0,0358 & 4,471 & 400,6 \\
\hline 34 & 0,034 & 0,0102 & 0,0342 & 4,471 & 400,6 \\
\hline 35 & 0,032 & 0,0097 & 0,0326 & 4,471 & 400,6 \\
\hline 36 & 0,031 & 0,0093 & 0,0311 & 4,471 & 400,6 \\
\hline 37 & 0,029 & 0,0088 & 0,0295 & 4,471 & 400,6 \\
\hline 38 & 0,028 & 0,0083 & 0,0280 & 4,471 & 400,6 \\
\hline 39 & 0,026 & 0,0079 & 0,0264 & 4,471 & 400,6 \\
\hline 40 & 0,025 & 0,0074 & 0,0249 & 4,471 & 400,6 \\
\hline 41 & 0,023 & 0,0070 & 0,0233 & 4,471 & 400,6 \\
\hline 42 & 0,022 & 0,0065 & 0,0218 & 4,471 & 400,6 \\
\hline 43 & 0,020 & 0,0060 & 0,0202 & 4,471 & 400,6 \\
\hline 44 & 0,019 & 0,0056 & 0,0187 & 4,471 & 400,6 \\
\hline 45 & 0,017 & 0,0051 & 0,0171 & 4,471 & 400,6 \\
\hline 46 & 0,015 & 0,0046 & 0,0155 & 4,471 & 400,6 \\
\hline 47 & 0,014 & 0,0042 & 0,0140 & 4,471 & 400,6 \\
\hline 48 & 0,012 & 0,0037 & 0,0124 & 4,471 & 400,6 \\
\hline 49 & 0,011 & 0,0032 & 0,0109 & 4,471 & 400,6 \\
\hline 50 & 0,009 & 0,0028 & 0,0093 & 4,471 & 400,6 \\
\hline 51 & 0,008 & 0,0023 & 0,0078 & 4,471 & 400,6 \\
\hline 52 & 0,006 & 0,0019 & 0,0062 & 4,471 & 400,6 \\
\hline 53 & 0,005 & 0,0014 & 0,0047 & 4,471 & 400,6 \\
\hline 54 & 0,003 & 0,0009 & 0,0031 & 4,471 & 400,6 \\
\hline 55 & 0,002 & 0,0005 & 0,0016 & 4,471 & 400,6 \\
\hline
\end{tabular}


Tabela B3 - Parâmetros de entrada para o modelo semi-empírico com perdas de energia.

\begin{tabular}{lcc}
\hline \multicolumn{1}{c}{ Parâmetros } & Valores & Unidades \\
\hline Linhas de orifícios & 5 & - \\
$\begin{array}{l}\text { Distância entre colunas } \\
\text { de orifícios }\end{array}$ & 0,08 & $\mathrm{~m}$ \\
$\begin{array}{l}\text { Colunas de orifícios } \\
\text { Diâmetro dos orifícios }\end{array}$ & 0,004 & - \\
$\begin{array}{l}\text { Massa especifica do ar } \\
\text { Vazão mássica de ar }\end{array}$ & 0,75 & $\mathrm{mg} / \mathrm{m}^{3}$ \\
$\begin{array}{l}\text { Altura da caixa } \\
\text { sopradora }\end{array}$ & 0,0855 & $\mathrm{~kg} / \mathrm{s}$ \\
$\begin{array}{l}\text { Largura inicial da caixa } \\
\text { sopradora }\end{array}$ & 0,085 & $\mathrm{~m}$ \\
$\begin{array}{l}\text { Fator de perda pela } \\
\text { saída no orifício }\end{array}$ & 0,18 & $\mathrm{~m}$ \\
$\begin{array}{l}\text { Fator de perda pela } \\
\text { expansão após o }\end{array}$ & 0,10 & - \\
$\begin{array}{l}\text { orifício } \\
\text { Velocidade do jato de ar } \\
\text { nos orifícios }\end{array}$ & 32,99 & $\mathrm{~m} / \mathrm{s}$ \\
\hline
\end{tabular}


Tabela B4 - Resultados de pressão interna, velocidade interna e perfil para a caixa sopradora para o modelo semi-empírico com perdas de energia.

\begin{tabular}{|c|c|c|c|c|c|}
\hline orifício k & $\begin{array}{c}\text { Largura da caixa } \\
\text { sopradora antes } \\
\text { do orifício k } \\
\text { m }\end{array}$ & $\begin{array}{c}\text { Área da seção transversal } \\
\text { da caixa sopradora antes } \\
\text { do furo } \mathrm{k} \\
\mathrm{m}^{2}\end{array}$ & $\begin{array}{c}\text { vazão mássica } \\
\text { antes do furo k } \\
\mathrm{kg} / \mathrm{s}\end{array}$ & $\begin{array}{c}\text { Velocidade no interior } \\
\text { da caixa sopradora } \\
\text { antes do orifício } k \\
\mathrm{~m} / \mathrm{s}\end{array}$ & $\begin{array}{c}\text { Pressão na caixa } \\
\text { sopradora antes do } \\
\text { orifício k } \\
\mathrm{Pa}\end{array}$ \\
\hline 1 & 0,085 & 0,0255 & 0,0855 & 4,471 & 415,3 \\
\hline 2 & 0,091 & 0,0274 & 0,0839 & 4,084 & 416,5 \\
\hline 3 & 0,091 & 0,0272 & 0,0824 & 4,041 & 416,7 \\
\hline 4 & 0,090 & 0,0270 & 0,0808 & 3,998 & 416,8 \\
\hline 5 & 0,089 & 0,0267 & 0,0793 & 3,955 & 416,9 \\
\hline 6 & 0,088 & 0,0265 & 0,0777 & 3,911 & 417,0 \\
\hline 7 & 0,088 & 0,0263 & 0,0762 & 3,867 & 417,2 \\
\hline 8 & 0,087 & 0,0260 & 0,0746 & 3,822 & 417,3 \\
\hline 9 & 0,086 & 0,0258 & 0,0731 & 3,777 & 417,4 \\
\hline 10 & 0,085 & 0,0255 & 0,0715 & 3,732 & 417,6 \\
\hline 11 & 0,084 & 0,0253 & 0,0700 & 3,686 & 417,7 \\
\hline 12 & 0,084 & 0,0251 & 0,0684 & 3,640 & 417,8 \\
\hline 13 & 0,083 & 0,0248 & 0,0668 & 3,593 & 417,9 \\
\hline 14 & 0,082 & 0,0246 & 0,0653 & 3,545 & 418,1 \\
\hline 15 & 0,081 & 0,0243 & 0,0637 & 3,498 & 418,2 \\
\hline 16 & 0,080 & 0,0240 & 0,0622 & 3,449 & 418,3 \\
\hline 17 & 0,079 & 0,0238 & 0,0606 & 3,400 & 418,4 \\
\hline 18 & 0,078 & 0,0235 & 0,0591 & 3,351 & 418,6 \\
\hline 19 & 0,077 & 0,0232 & 0,0575 & 3,300 & 418,7 \\
\hline 20 & 0,077 & 0,0230 & 0,0560 & 3,250 & 418,8 \\
\hline 21 & 0,076 & 0,0227 & 0,0544 & 3,198 & 418,9 \\
\hline 22 & 0,075 & 0,0224 & 0,0529 & 3,146 & 419,1 \\
\hline 23 & 0,074 & 0,0221 & 0,0513 & 3,093 & 419,2 \\
\hline 24 & 0,073 & 0,0218 & 0,0497 & 3,039 & 419,3 \\
\hline 25 & 0,072 & 0,0215 & 0,0482 & 2,985 & 419,4 \\
\hline 26 & 0,071 & 0,0212 & 0,0466 & 2,930 & 419,6 \\
\hline 27 & 0,070 & 0,0209 & 0,0451 & 2,874 & 419,7 \\
\hline 28 & 0,069 & 0,0206 & 0,0435 & 2,817 & 419,8 \\
\hline 29 & 0,068 & 0,0203 & 0,0420 & 2,759 & 419,9 \\
\hline 30 & 0,067 & 0,0200 & 0,0404 & 2,700 & 420,0 \\
\hline 31 & 0,065 & 0,0196 & 0,0389 & 2,640 & 420,2 \\
\hline 32 & 0,064 & 0,0193 & 0,0373 & 2,578 & 420,3 \\
\hline 33 & 0,063 & 0,0189 & 0,0358 & 2,516 & 420,4 \\
\hline 34 & 0,062 & 0,0186 & 0,0342 & 2,452 & 420,5 \\
\hline 35 & 0,061 & 0,0182 & 0,0326 & 2,387 & 420,6 \\
\hline 36 & 0,060 & 0,0179 & 0,0311 & 2,321 & 420,8 \\
\hline 37 & 0,058 & 0,0175 & 0,0295 & 2,252 & 420,9 \\
\hline 38 & 0,057 & 0,0171 & 0,0280 & 2,183 & 421,0 \\
\hline 39 & 0,056 & 0,0167 & 0,0264 & 2,111 & 421,1 \\
\hline 40 & 0,054 & 0,0163 & 0,0249 & 2,037 & 421,2 \\
\hline 41 & 0,053 & 0,0159 & 0,0233 & 1,961 & 421,3 \\
\hline 42 & 0,051 & 0,0154 & 0,0218 & 1,882 & 421,5 \\
\hline 43 & 0,050 & 0,0150 & 0,0202 & 1,801 & 421,6 \\
\hline 44 & 0,048 & 0,0145 & 0,0187 & 1,716 & 421,7 \\
\hline 45 & 0,047 & 0,0140 & 0,0171 & 1,628 & 421,8 \\
\hline 46 & 0,045 & 0,0135 & 0,0155 & 1,536 & 421,9 \\
\hline 47 & 0,043 & 0,0130 & 0,0140 & 1,439 & 422,0 \\
\hline 48 & 0,041 & 0,0124 & 0,0124 & 1,337 & 422,1 \\
\hline 49 & 0,039 & 0,0118 & 0,0109 & 1,227 & 422,2 \\
\hline 50 & 0,037 & 0,0112 & 0,0093 & 1,109 & 422,3 \\
\hline 51 & 0,035 & 0,0106 & 0,0078 & 0,979 & 422,4 \\
\hline 52 & 0,033 & 0,0099 & 0,0062 & 0,834 & 422,5 \\
\hline 53 & 0,031 & 0,0094 & 0,0047 & 0,664 & 422,6 \\
\hline 54 & 0,031 & 0,0093 & 0,0031 & 0,445 & 422,7 \\
\hline 55 & 0,030 & 0,0091 & 0,0016 & 0,227 & 422,8 \\
\hline
\end{tabular}

